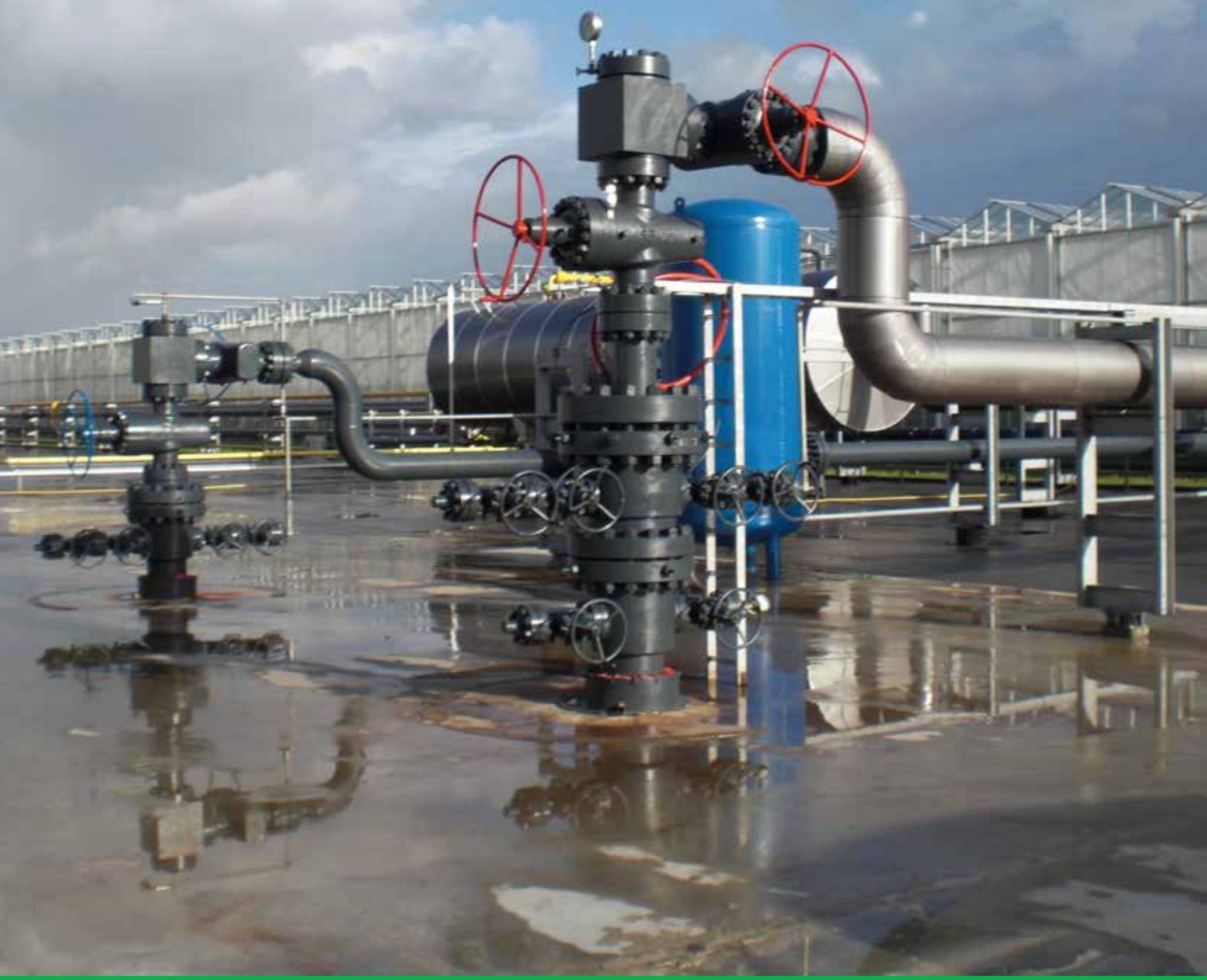

\title{
Energiemonitor van de Nederlandse glastuinbouw 2016
}





\section{Energiemonitor van de Nederlandse glastuinbouw 2016}

Nico van der Velden en Pepijn Smit

Dit onderzoek is uitgevoerd door Wageningen Economic Research in opdracht van en gefinancierd door het ministerie van Economische Zaken en de stichting Programmafonds Glastuinbouw/LTO Glaskracht Nederland.

Wageningen Economic Research

Wageningen, oktober 2017

RAPPORT

2017-094

ISBN 978-94-6343-800-1 
Van der Velden, Nico en Pepijn Smit, 2017. Energiemonitor van de Nederlandse glastuinbouw 2016. Wageningen, Wageningen Economic Research, Rapport 2017-094. 50 blz.; 25 fig.; 4 tab.; 14 ref.

In de Meerjarenafspraak Energietransitie Glastuinbouw 2014-2020 is tussen glastuinbouwsector en overheid een doel voor de totale $\mathrm{CO}_{2}$-missie in 2020 van 6,2 Mton overeengekomen. Hierop is in 2017 door de convenantspartijen een technisch correctie toegepast tot 4,6 Mton. Uit de Energiemonitor van de Nederlandse glastuinbouw blijkt dat in 2016 de $\mathrm{CO}_{2}$-emissie daalde naar 5,6 Mton. De glastuinbouw zat in 2016 hiermee onder het oorspronkelijke doel en boven de technische correctie. In de periode 2010-2016 daalde de $\mathrm{CO}_{2}$-emissie met 2,5 Mton. Na temperatuurcorrectie is dit 2,2 Mton. Dit kwam door krimp van het areaal, minder verkoop elektriciteit, toename duurzame energie, minder inkoop warmte, meer inkoop elektriciteit, intensivering, extensivering en energiebesparing. Ondanks de lagere energiekosten in 2016 is de energiebesparing verder toegenomen. Het aandeel duurzame energie in het totaal energiegebruik groeide in 2016 van 4,8 tot 5,5\%. Deze groei zat bij aardwarmte en inkoop duurzame elektriciteit. De energie-efficiëntie is in 2016 met 1 procentpunt verbeterd door een daling van het primair brandstofverbruik en een stijging van de fysieke productie.

In the Long-term agreement for energy transition in the greenhouse horticulture sector 2014-2020, the greenhouse horticulture sector and the Dutch government agreed a target of 6.2 megatonnes in total $\mathrm{CO}_{2}$ emissions. In 2017, the agreement participants made a technical correction and adjusted this target to 4.6 megatonnes. The Dutch Greenhouse Horticulture Energy Monitor indicated that that $\mathrm{CO}_{2}$ emissions dropped to 5.6 megatonnes in 2016. This means that the greenhouse horticulture sector fell under the original target, but remains above the technical correction. A reduction of 2.5 megatonnes in $\mathrm{CO}_{2}$ emissions was measured between 2010 and 2016. Following a temperature correction this figure is 2.2 megatonnes. This was the result of acreage shrinkage, reduced sales of electricity, increase in sustainable energy, reduced purchasing of heat, increased electricity purchasing, intensification, extensification and energy savings. Despite the lower energy costs recorded in 2016, energy savings increased. In 2016, the proportion of sustainable energy in terms of total energy consumption increased from $4.8 \%$ to $5.5 \%$. This increase was noted in geothermal energy and purchasing of sustainable electricity. Energy efficiency improved by 1 percentage point in 2016 as a result of a drop in the consumption of primary fuels and an increase in physical production.

Trefwoorden: energie, $\mathrm{CO}_{2}$-emissie, energie-efficiëntie, duurzame energie, wkk, inkoop warmte, glastuinbouw

Dit rapport is gratis te downloaden op https://doi.org/10.18174/424123 of op www. wur. nl/economicresearch (onder Wageningen Economic Research publicaties).

(C) 2017 Wageningen Economic Research

Postbus 29703, 2502 LS Den Haag, T 07033583 30, E communications.ssg@wur.nl, www. wur.nl/economic-research. Wageningen Economic Research is onderdeel van Wageningen University \& Research.

\section{(cc) BY-NC}

Wageningen Economic Research hanteert voor haar rapporten een Creative Commons Naamsvermelding 3.0 Nederland licentie.

(c) Wageningen Economic Research, onderdeel van Stichting Wageningen Research, 2017 De gebruiker mag het werk kopiëren, verspreiden en doorgeven en afgeleide werken maken. Materiaal van derden waarvan in het werk gebruik is gemaakt en waarop intellectuele eigendomsrechten berusten, mogen niet zonder voorafgaande toestemming van derden gebruikt worden. De gebruiker dient bij het werk de door de maker of de licentiegever aangegeven naam te vermelden, maar niet zodanig dat de indruk gewekt wordt dat zij daarmee instemmen met het werk van de gebruiker of het gebruik van het werk. De gebruiker mag het werk niet voor commerciële doeleinden gebruiken.

Wageningen Economic Research aanvaardt geen aansprakelijkheid voor eventuele schade voortvloeiend uit het gebruik van de resultaten van dit onderzoek of de toepassing van de adviezen.

Wageningen Economic Research is ISO 9001:2008 gecertificeerd.

Wageningen Economic Research Rapport 2017-094 | Projectcode 2282200274

Foto omslag: Wageningen University \& Research 


\section{Inhoud}

Woord vooraf $\quad 5$

$\begin{array}{ll}\text { Samenvatting } & 6\end{array}$

S.1 $\mathrm{CO}_{2}$-emissie glastuinbouw in 2016 verder gedaald $\quad 6$

$\begin{array}{lll}\text { S.2 Overige uitkomsten } & 7\end{array}$

$\begin{array}{lll}\text { S.3 Methode } & 8\end{array}$

$\begin{array}{ll}\text { Summary } & 9\end{array}$

S1 Further reductions in $\mathrm{CO}_{2}$ emissions in the greenhouse horticulture sector in $2016 \quad 9$

$\begin{array}{ll}\text { S.2 Complementary findings } & 10\end{array}$

$\begin{array}{ll}\text { S.3 Method } & 11\end{array}$

1

Inleiding

$\begin{array}{lll}1.1 & \text { Beleidsmatige context } & 12\end{array}$

$\begin{array}{lll}1.2 & \text { De Energiemonitor } & 14\end{array}$

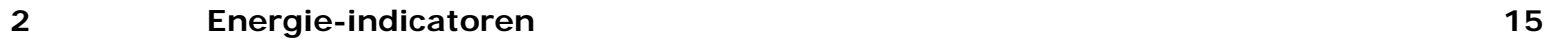

$\begin{array}{lll}2.1 & \text { Inleiding } & 15\end{array}$

$\begin{array}{lll}2.2 \mathrm{CO}_{2} \text {-emissie } & 15\end{array}$

$\begin{array}{lll}2.3 & \text { Energie-efficiëntie } & 16\end{array}$

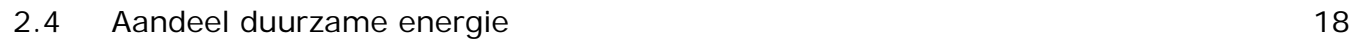

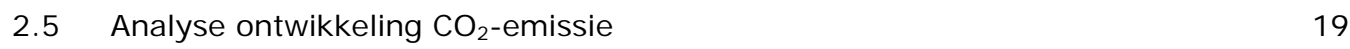

$\begin{array}{lll}2.6 & \text { Energiekosten en energievraag } & 21\end{array}$

$3 \quad$ Duurzame energie $r$

3.1 Inleiding $\quad 24$

$\begin{array}{lll}3.2 & \text { Vormen van duurzame energie } & 24\end{array}$

3.2.1 Toepassing 24

$\begin{array}{ll}3.2 .2 & \text { Ontwikkeling per vorm }\end{array}$

3.2.3 Productie, inkoop, verkoop en consumptie $\quad 27$

3.2.4 Bedrijfsstructuur 29

3.3 Inkoop $\mathrm{CO}_{2} \quad 31$

3.4 Reductie $\mathrm{CO}_{2}$-emissie $\quad 31$

4 Warmtekrachtkoppeling, inkoop warmte en elektriciteitsbalans

33

4.1 Inleiding 33

4.2 Warmtekrachtkoppeling glastuinbouwbedrijven 33

4.3 Inkoop warmte $\quad 35$

4.4 Reductie $\mathrm{CO}_{2}$-emissie $\quad 35$

$\begin{array}{lll}4.5 & \text { Elektriciteitsbalans } & 37\end{array}$ 
Bijlage 1 Definities, methode en bronnen

Bijlage 2 Kenmerken en energie-indicatoren glastuinbouw

Bijlage 3 Energiegebruik glastuinbouw (totale glastuinbouwareaal en niet gecorrigeerd voor temperatuur) a)

Bijlage 4 Gebruik en reductie $\mathrm{CO}_{2}$-emissie per duurzame energiebron en inkoop $\mathrm{CO}_{2}$

Bijlage 5 Gebruik en reductie $\mathrm{CO}_{2}$-emissie wkk en inkoop warmte 


\section{Woord vooraf}

In 2014 maakten de glastuinbouwsector en de rijksoverheid de Meerjarenafspraak Energietransitie Glastuinbouw 2014-2020. In deze Meerjarenafspraak staat de $\mathrm{CO}_{2}$-emissie centraal. Het doel voor 2020 is een maximale $\mathrm{CO}_{2}$-emissie van 6,2 Mton. Dit doel is onderdeel van de Nederlandse taakstelling voor het Europese doel om in 2020 20\% minder broeikasgassen uit te stoten in vergelijking met 1990. Door het akkoord van Parijs uit 2015 zal de uitstoot van broeikasgassen na 2020 verder omlaag moeten. In de Meerjarenafspraak is ook beschreven dat de glastuinbouw in 2050 een volledig duurzame en economisch rendabele energievoorziening wil hebben. Deze ambitie betekent dat de glastuinbouw in 2050 geen $\mathrm{CO}_{2}$-emissie meer kent.

In het programma Kas als Energiebron (KaE) werken de glastuinbouw en de overheid gezamenlijk aan het realiseren van de doelen en ambities in de Meerjarenafspraak. De ambities zijn dat vanaf 2020 in nieuw te bouwen kassen op economisch rendabele wijze netto klimaatneutraal geproduceerd kan worden en dat dit in bestaande de kassen kan met de helft van de fossiele brandstof ten opzichte van 2011. Op de langere termijn is de ambitie dat in 2050 de glastuinbouw een volledig duurzame en economisch rendabele energievoorziening heeft. Speerpunten van de publiek private samenwerking $\mathrm{KaE}$ op de kortere termijn zijn het versnellingsplan voor Het Nieuwe Telen, het versnellingsplan aardwarmte, energiewinst in de regio en het plan innovatieve doorbraken voor energiebesparing.

Om rationele keuzes te kunnen maken in beleid en belangenbehartiging is het belangrijk de werkelijke ontwikkelingen in beeld te hebben. De Energiemonitor van de Nederlandse glastuinbouw kwantificeert en analyseert de ontwikkeling van het energiegebruik en de energie-indicatoren. Uit de Energiemonitor blijkt dat de $\mathrm{CO}_{2}$-emissie van de glastuinbouw de laatste jaren structureel is gedaald en onder het doel voor 2020 uit de Meerjarenafspraak zit. De glastuinbouw doet het bij het terugdringen van de $\mathrm{CO}_{2}$-emsie beter dan de landelijke ontwikkeling. Twee belangrijke oorzaken van de reductie van de $\mathrm{CO}_{2}$-emissie zijn krimp van het areaal en minder verkoop elektriciteit en dat zal in de periode tot 2020 ook het geval zijn. Dit betreft geen inspanning door de glastuinbouw. De convenantspartijen hebben met kennis van deze ontwikkelingen besloten om het oorspronkelijke $\mathrm{CO}_{2-}$ doel voor de glastuinbouw technisch te corrigeren conform de afspraken in het convenant. Hieruit resulteert een $\mathrm{CO}_{2}$-doel voor 2020 na technische correctie van 4,6 Mton.

De Energiemonitor wordt ook als basis gebruikt voor ander onderzoek. Zo heeft Wageningen Economic Research in 2016 een prognose gemaakt van de $\mathrm{CO}_{2}$-emissie in 2020 waaruit blijkt dat de $\mathrm{CO}_{2}$-emissie van de glastuinbouw verder zal dalen. In 2017 is een nadere analyse gepubliceerd van de effecten van intensivering, extensivering en energiebesparing op de $\mathrm{CO}_{2}$-emissie waaruit blijkt dat de glastuinbouw een substantiële energiebesparing heeft gerealiseerd. In 2017 is een project gestart waarin een prognose voor 2030 wordt gemaakt.

Wageningen Economic Research maakt jaarlijks de Energiemonitor Glastuinbouw in opdracht van de Stichting Programmafonds Glastuinbouw/LTO Glaskracht Nederland en het ministerie van Economische Zaken (EZ) in het kader van KaE. De leden van de begeleidingscommissie zijn P. Broekharst (LTO Glaskracht Nederland), M. Root (Ministerie van Economische Zaken) en K. Poppe (Wageningen Economic Research). Vele partijen hebben voor dit project informatie aangeleverd. Aan het onderzoek werkten mee Nico van der Velden (projectleider), Pepijn Smit, Ruud van der Meer en Jeroen Hammerstein.

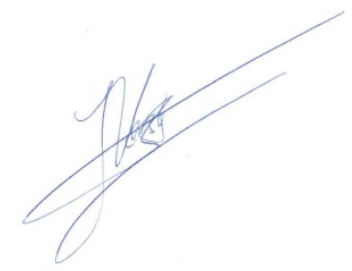

Prof.dr.ir. J.G.A.J. (Jack) van der Vorst Algemeen Directeur Social Sciences Group (SSG)

Wageningen University \& Research 


\section{Samenvatting}

\section{S.1 $\mathrm{CO}_{2}$-emissie glastuinbouw in 2016 verder gedaald}

De totale $\mathrm{CO}_{2}$-emissie van de glastuinbouw daalde in 2016 met 0,2 Mton naar 5,6 Mton en ligt daarmee 0,6 Mton onder het oorspronkelijke doel voor 2020 (6,2 Mton). In vergelijking met het doel voor 2020 na technische correctie (4,6 Mton) lag de $\mathrm{CO}_{2}$-emissie in 2016 hoger. Om dit doel te realiseren dient de emissie met nog 1,0 Mton te worden gereduceerd.

De totale $\mathrm{CO}_{2}$-emissie lag in 2016 1,2 Mton (18\%) onder het niveau van 1990. Voor Nederland als geheel lag de $\mathrm{CO}_{2}$-emissie $9 \%$ hoger dan in 1990. De glastuinbouw doet het dus beter dan de landelijke ontwikkeling (zie paragraaf 2.2).

In de periode 2010-2016 daalde de totale $\mathrm{CO}_{2}$-emissie met 2,5 Mton. Na temperatuurcorrectie was de daling 2,2 Mton. Deze daling kan voor 77\% worden verklaard door krimp van het areaal, minder verkoop elektriciteit, meer duurzame energie, minder inkoop warmte en meer inkoop elektriciteit. Het resterende aandeel van $23 \%$ wordt verklaard door het saldo van de factoren intensivering, extensivering en energiebesparing. Het effect van deze drie factoren was in de periode 2010-2016 groter dan in de periode 2010-2015. Doordat de intensivering zich in 2016 verder ontwikkeld heeft en de extensivering is verminderd, kan geconcludeerd worden dat het effect van energiebesparing op de $\mathrm{CO}_{2}$-emissie in 2016 verder is toegenomen (zie paragraaf 2.5) ondanks de verdere daling van de energiekosten (zie paragraaf 2.6).

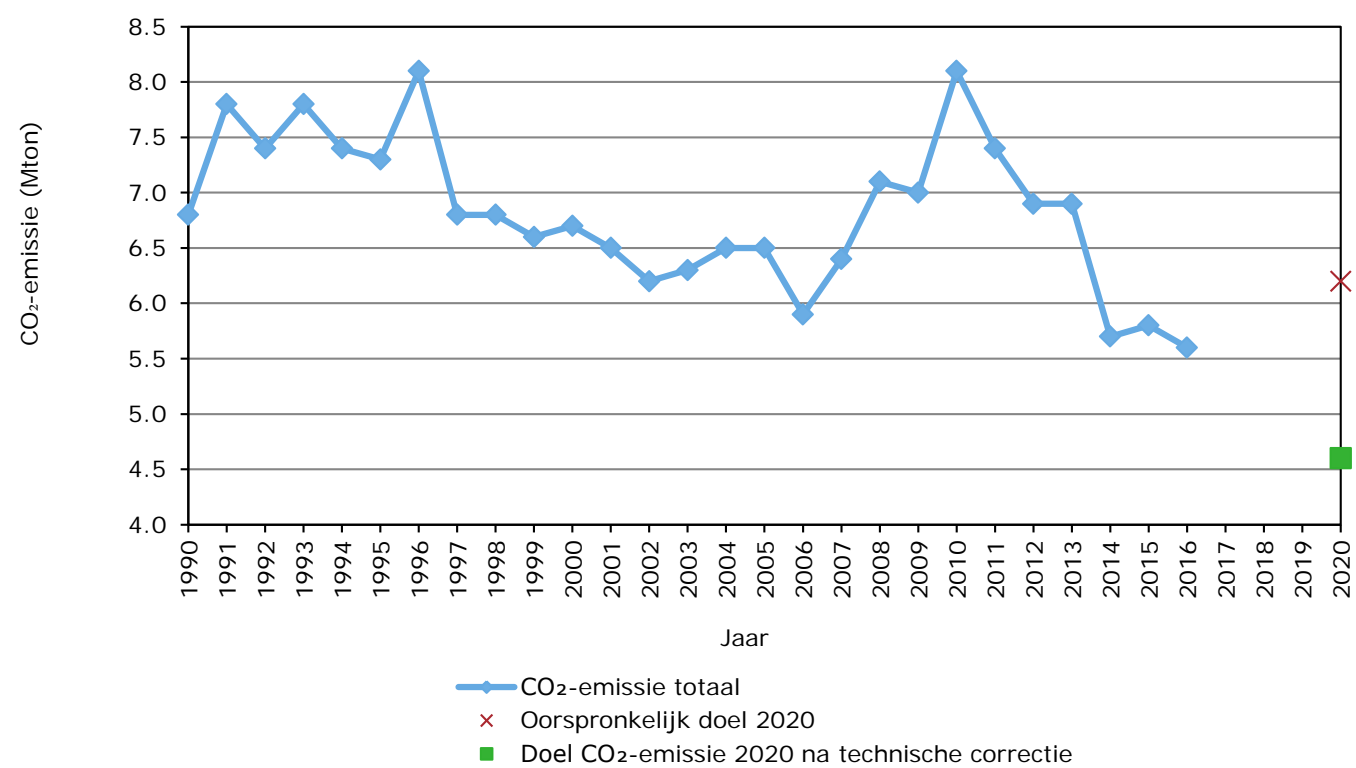

Figuur S.1 $\mathrm{CO}_{2}$-emissie totaal a)

a) Cijfers 2016 voorlopig. 


\section{S.2 Overige uitkomsten}

Energie-efficiëntie

De index van de energie-efficiëntie liet in 2016 een verbetering zien van 1 procentpunt en kwam uit op $41 \%$. De glastuinbouw gebruikte daarmee $59 \%$ minder primair brandstof per eenheid product dan in 1990. De verbetering in 2016 komt door een afname van het primair brandstofverbruik per $\mathrm{m}^{2}$ met $1 \%$ en een toename van de fysieke productie per $\mathrm{m}^{2}$ met $0,5 \%$ (zie paragraaf 2.3 ).

Duurzame energie

Het aandeel duurzame energie groeide in 2016 met 0,6 procentpunt naar 5,5\%. Het absolute gebruik steeg met 0,6 PJ naar 5,4 PJ. Door daling van het totaal energiegebruik in de glastuinbouw steeg het aandeel duurzaam meer dan van het absolute gebruik. Het groeitempo nam in 2016 ten opzichte van 2014 en 2015 wel af. Dit kwam enerzijds door technische problemen bij aardwarmteprojecten en anderzijds door minder nieuwe duurzame energieprojecten. Relatief lage energieprijzen speelden hierbij ook een rol. In 2016 voorzag aardwarmte in 50\% van de toegepaste duurzame energie, op afstand gevolgd door inkoop van duurzame elektriciteit (17\%), de inzet van zonne-energie (14\%), biobrandstoffen (13\%), inkoop duurzame warmte (5\%) en inkoop duurzaam gas (1\%). De groei zat in 2016 bij aardwarmte en inkoop duurzame elektriciteit. Het aandeel duurzaam in de glastuinbouw loopt achter op het aandeel voor Nederland als geheel, dat 6,0\% bedroeg, wel groeit duurzame in de glastuinbouw sneller (zie paragraaf 2.4).

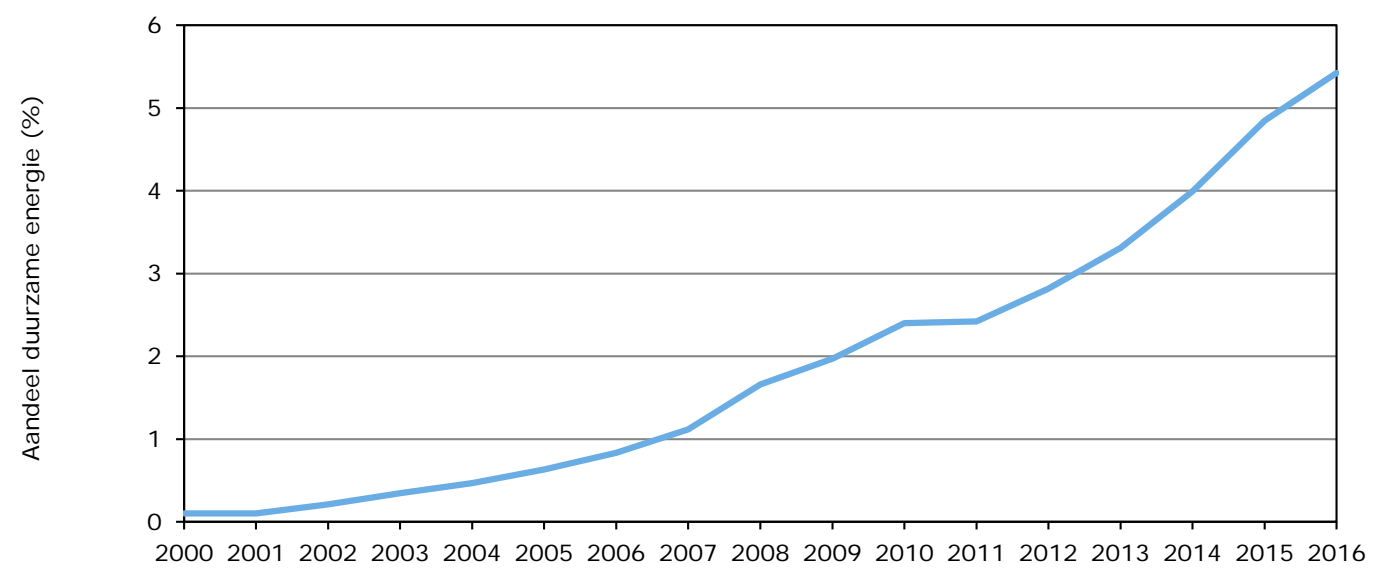

Jaar

Figuur S.2 Aandeel duurzame energie a)

a) Cijfers 2016 voorlopig.

Energiekosten en -gebruik

De netto-energiekosten per $\mathrm{m}^{2}$ kas daalden in de periode 2013-2016 sterk en lagen in 2016 zo'n 35\% onder het niveau van 2013. De daling kwam door lagere prijzen en een lager energiegebruik. De warmteconsumptie per $\mathrm{m}^{2}$ nam in de periode 2006-2014 af en werd voor een belangrijk deel gecompenseerd door groei van de elektriciteitsconsumptie. De verschuiving van warmte naar elektriciteit kwam vooral door intensivering in de vorm van groeilicht. Vanaf 2014 lijkt deze verschuiving te stabiliseren.

Warmtekrachtkoppeling, inkoop warmte en elektriciteitsbalans

Het totale vermogen van het warmtekrachtpark van de glastuinbouw was per eind 2016 circa 2.7002.800 $\mathrm{MW}_{\mathrm{e}}$ en laat sinds 2012 een daling zien. De daling komt door krimp van het areaal, verslechterde spark spread en toename van duurzame energie. De gemiddelde gebruiksduur van de wkk is in de periode 2011-2016 met bijna $20 \%$ gedaald. 
De elektriciteitsproductie door wkk daalde in de periode 2013-2016 met zo'n 23\% tot 9 miljard kWh en dekte daarmee in 2016 8\% van de nationale consumptie. De verkoop van elektriciteit nam in de periode 2010-2016 met bijna 40\% af tot 4,9 miljard kWh; in de jaren 2010-2014 was deze daling sterker dan in 2015 en 2016. De inkoop van elektriciteit beweegt zich in de periode 2010-2014 tussen de 2,2 en 2,5 miljard kWh per jaar. De jaren 2015 en 2016 lieten een toename zien tot 2,6 miljard kWh. In de periode 2010-2016 daalde de netto-verkoop van 6,2 naar 2,3 miljard kWh. Dit is en daling van ruim $60 \%$ in 6 jaar. De elektriciteitsconsumptie bedraagt in 2016 naar schatting ruim 7 miljard kWh. Dit komt overeen $6 \%$ van de nationale consumptie. De elektriciteitsconsumptie op sectorniveau nam in de periode 2005-2013 toe en lijkt in de jaren daarna te stabiliseren. Dit laatste hangt samen met de groei van het areaal belichting bij tomaat en krimp van het areaal sierteeltgewassen met belichting. Per $\mathrm{m}^{2}$ kas lijkt de elektriciteitsconsumptie iets toe te nemen.

De hoeveelheid ingekochte warmte nam in 2015 en 2016 na vele jaren van teruggang weer iets toe door uitbreiding van het areaal dat gebruik maakt van ingekochte warmte en een relatief koude winter. Inkoop warmte had in 2016 een aandeel in het totale energiegebruik van de glastuinbouw van bijna $4 \%$.

\section{S.3 Methode}

In opdracht van de Stichting Programmafonds Glastuinbouw/LTO Glaskracht Nederland en het ministerie van Economische Zaken kwantificeert Wageningen Economic Research jaarlijks de ontwikkeling van de energie-indicatoren $\mathrm{CO}_{2}$-emissie, energie-efficiëntie en aandeel duurzame energie in de glastuinbouw. Hiervoor worden de energiebalans en de fysieke productie in kaart gebracht. Om de kwantificering te duiden, worden achtergronden geanalyseerd. Voor de Energiemonitor Glastuinbouw is een methodiek ontwikkeld waarin sectordeskundigen een reeks van informatiebronnen combineren. Deze methode is vastgelegd in een protocol. 


\section{Summary}

\section{$\mathrm{S} 1$ Further reductions in $\mathrm{CO}_{2}$ emissions in the greenhouse horticulture sector in 2016}

The total $\mathrm{CO}_{2}$ emissions of the greenhouse horticulture sector decreased by 0.2 megatonnes to 5.6 megatonnes in 2016 and is therefore 0.6 megatonnes under the original goal of 6.2 megatonnes in 2020. Compared to the 2020 goal after the technical correction to 4.6 megatonnes, the $\mathrm{CO}_{2}$ emissions in 2016 were higher. In order to achieve that goal, emissions will need to decrease by a further 1.0 megatonnes.

The total $\mathrm{CO}_{2}$ emissions in 2016 was 1,2 megatonnes (18\%) less than in 1990. For the Netherlands in general, $\mathrm{CO}_{2}$ emissions were $9 \%$ higher than in 1990. This means that that greenhouse horticulture sector is ahead of national development (see paragraph 2.2).

A reduction of 2.5 megatonnes in $\mathrm{CO}_{2}$ emissions was measured between 2010 and 2016 . Following the correction for temperature, this decrease was set at 2.2 megatonnes. $77 \%$ of this decrease can be ascribed to acreage shrinkage, reduced sale of electricity, increase in sustainable energy, more electricity purchasing and reduced purchasing of heat. The remaining $23 \%$ can be attributed to the balance of the factors intensification, extensification and energy savings. The effects of these three factors were larger in the 2010-2016 period than in the 2010-2015 period. As intensification further developed in 2016 while extensification decreased, it can be concluded that the effect of energy savings on $\mathrm{CO}_{2}$ emissions in 2016 has increased (see paragraph 2.5) despite the further reduction in energy costs (see paragraph 2.6).

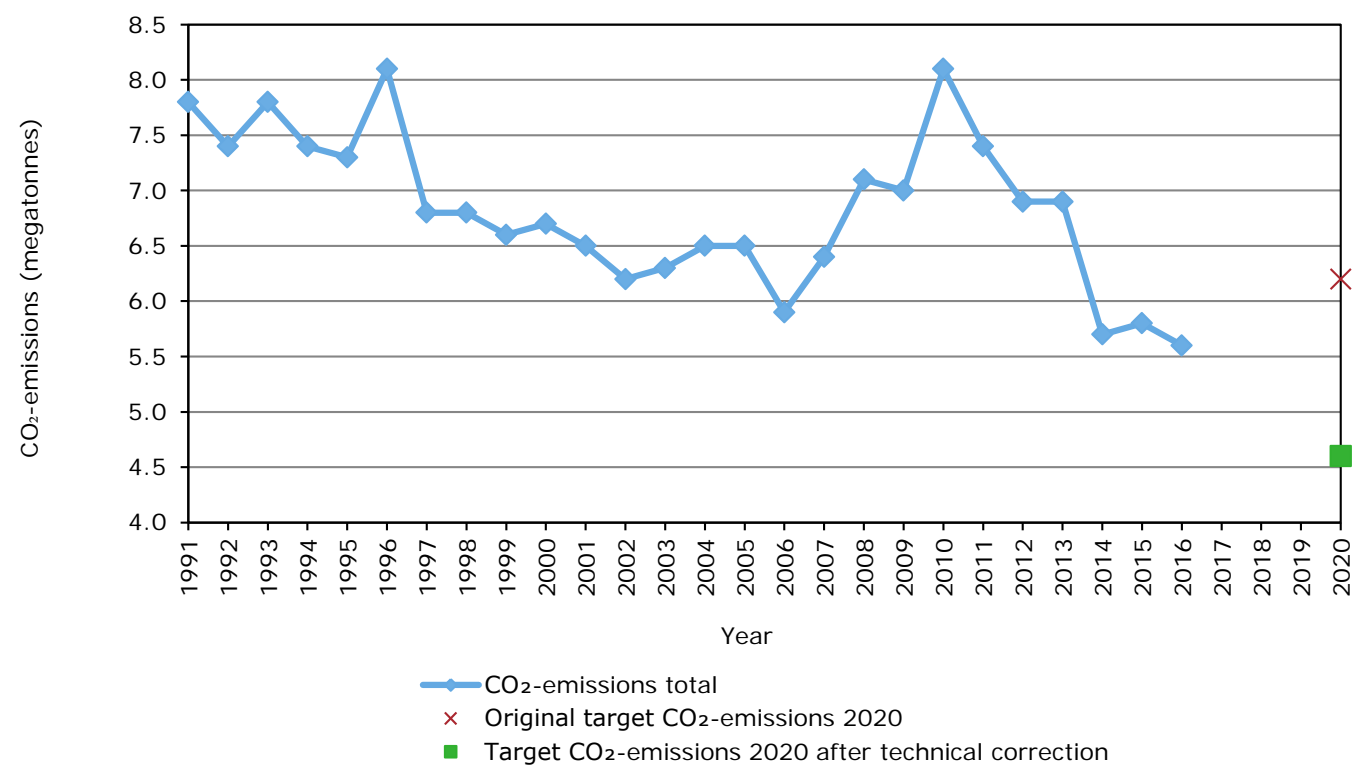

Figure S.1 Total $\mathrm{CO}_{2}$ emissions a)

a) Provisional numbers for 2016 


\section{S.2 Complementary findings}

Energy efficiency

In 2016, the energy efficiency index showed an improvement of one percentage point to $41 \%$. This means the greenhouse horticulture sector used 59\% less primary fuel per unit of product compared to 1990. The improvement in 2016 was due to a $1 \%$ decrease in primary fuel consumption per $\mathrm{m}^{2}$ and a $0.5 \%$ per $\mathrm{m}^{2}$ increase in physical production per $\mathrm{m}^{2}$ (see paragraph 2.3 ).

\section{Sustainable energy}

In 2016, the proportion of sustainable energy increased with 0.6 percentage points to $5.5 \%$. The absolute use increased with 0.6 PJ to 5.4 PJ. Because of the decrease in total energy usage in the greenhouse horticulture sector, the growth of the proportion of sustainable energy increased by more than that seen in absolute usage. In 2016, the rate of growth decreased when compared to 2014 and 2015. This was caused by technical problems with geothermal heat projects on the one hand and fewer new sustainable energy projects on the other. Relatively low energy prices also played a role. In 2016, geothermal energy represented $50 \%$ of the used sustainable energy, distantly followed by the purchasing of sustainable electricity at $17 \%$, the use of solar energy at $14 \%$, biofuels at $13 \%$, purchasing of sustainable heat at $5 \%$ and the purchasing of sustainable gas at $1 \%$. Increase was noted in 2016 in geothermal energy and the purchase of sustainable electricity. The share of sustainable resources in the greenhouse horticulture sector is less than the Netherlands as a whole, which is $6.0 \%$. However, the greenhouse horticulture sector records faster growth in this area (see paragraph 2.4).

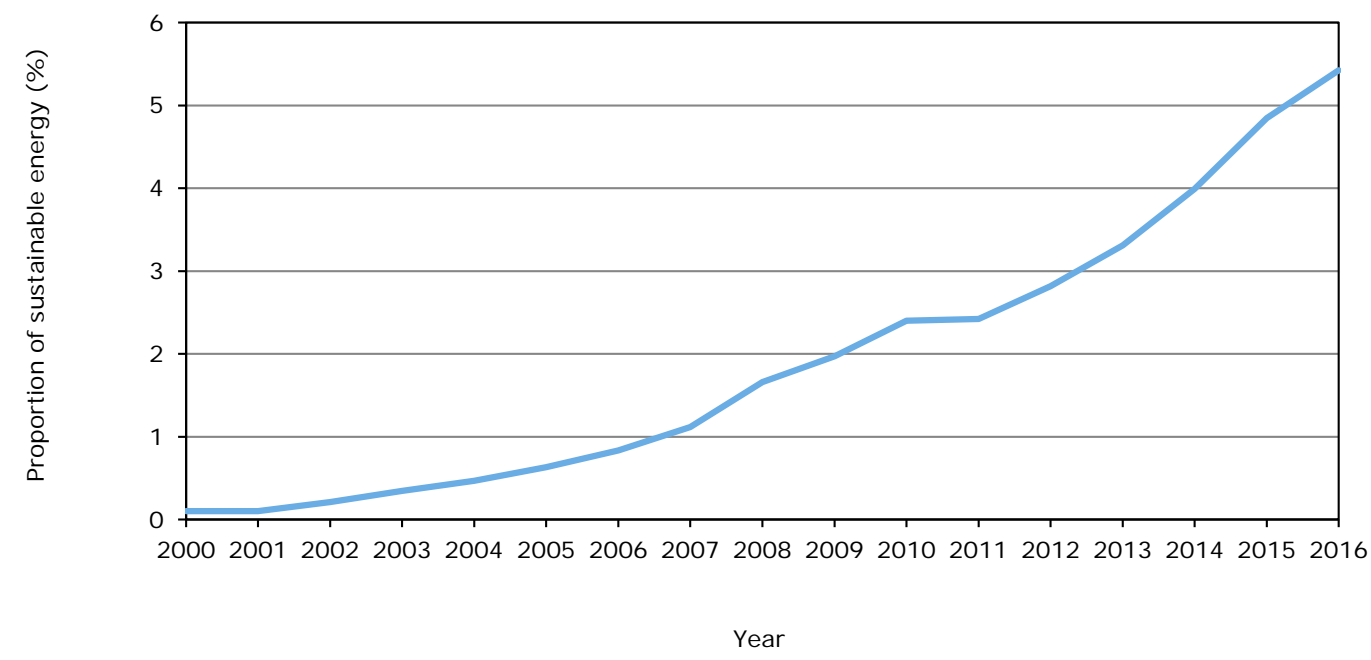

Figure S.2 Proportion of sustainable energy a)

a) Provisional numbers for 2016

Energy costs and usage

The net energy costs per $\mathrm{m}^{2}$ greenhouse dropped sharply in the 2013-2016 period and were 35\% lower in 2016 than those recorded in 2013. This drop can be ascribed to lower tariffs and lower energy use. Heat consumption per $\mathrm{m}^{2}$ decreased between 2006 and 2014 and is largely compensated by a growth in electricity consumption. This shift from heat to electricity was predominantly caused by the intensification of assimilation lighting. This shift appears to have stabilised since 2014.

Combined heat and power system, heat purchasing and electricity balance

The total capacity of the combustion heat and power (CHP) facilities in the greenhouse horticulture sector stood at approximately 2,700 - 2,800 MWe at the end of 2016 and has been declining since 2012. This decline is attributed to a decrease in the acreage, a reduction in spark spread and the 
increase in sustainable energy. The average duration of use of the CHP has dropped by nearly $20 \%$ between 2011 and 2016.

CHP electricity production dropped by $23 \%$ to 9 billion kWh between 2013 and 2016 and covered $8 \%$ of the national consumption. The purchasing of electricity decreased by nearly $40 \%$ to 4.9 billion kWh in the 2010-2016 period. This decrease was stronger between 2010-2014 than it was in 2015 and 2016. Purchasing remained between 2.2 billion and 2.5 billion kWh per year in the period 2010-2014. In 2015 and 2016 this increased to 2.6 billion kWh. Between 2010 and 2016 net sales dropped from 6.2 to 2.3 billion kWh. This marks a decrease of over $60 \%$ in six years. In 2016 , electricity consumption is estimated to amount to 7 billion $\mathrm{kWh}$. This corresponds with $6 \%$ of national consumption. Electricity consumption at sector level increased between 2005 and 2013 and appears to have stabilised in the following years. This corresponds to the growth of acreage with assimilation lighting for tomatoes and the shrinkage of the acreage with assimilation lighting for ornamentals. Electricity consumption per $\mathrm{m}^{2}$ of greenhouse appears to be increasing slightly.

The amount of purchased heat increased slightly in 2015 and 2016 following many years of decrease due to the extension of the acreage that used purchased heat and a relatively cold winter. In 2016, heat purchasing accounted for nearly $4 \%$ of the total energy use of the greenhouse horticulture sector.

\section{S.3 Method}

Wageningen Economic Research has been commissioned by LTO Glaskracht Nederland ${ }^{1}$ and the Dutch Ministry of Economic Affairs to quantify annually the developments of the indicators for $\mathrm{CO}_{2}$ emissions, energy efficiency and the share of sustainable energy in the greenhouse horticulture. This is worked out by mapping out the energy balance and physical production. To indicate the quantification, backgrounds are analysed. The Greenhouse Horticulture Energy Monitor is based on a method in which sector experts combine several different information sources. This method has been described in detail in a protocol.

\footnotetext{
${ }^{1}$ Branch organisation for Dutch greenhouse horticulture for energy innovation and transition.
} 


\section{$1 \quad$ Inleiding}

\subsection{Beleidsmatige context}

Meerjarenafspraak Energietransitie Glastuinbouw

Tussen de Nederlandse glastuinbouw en de Nederlandse overheid is in 2014 de Meerjarenafspraak Energietransitie Glastuinbouw 2014-2020 gemaakt. In deze Meerjarenafspraak staat, voortbouwend op het Convenant $\mathrm{CO}_{2}$-emissieruimte binnen het $\mathrm{CO}_{2}$-sectorsysteem glastuinbouw, de totale $\mathrm{CO}_{2}$-emissie centraal. Het doel in de Meerjarenafspraak is een maximale totale $\mathrm{CO}_{2}$-emissie van 6,2 Mton in 2020. Dit doel is onderdeel van de Nederlandse taakstelling voor het Europese doel om in $202020 \%$ minder $\mathrm{CO}_{2}$ uit te stoten in vergelijking met 1990.

Technische correctie

De $\mathrm{CO}_{2}$-emissie van de glastuinbouw in de periode 2010-2015 sterk gedaald (Van der Velden en Smit, 2015) en uit de prognose van de $\mathrm{CO}_{2}$-emissie in 2020 blijkt een verdere daling (Van der Velden en Smit, 2017). De achterliggende en toekomstige reductie van de $\mathrm{CO}_{2}$-emissie komt voor een belangrijk deel door krimp van het areaal en minder verkoop van elektriciteit vanuit wkk. Deze ontwikkelingen waren geen resultaat van inspanning door de glastuinbouw. De convenantspartijen hebben daarom besloten om de $\mathrm{CO}_{2}$-emissieruimte c.q. het $\mathrm{CO}_{2}$-doel voor de glastuinbouw in 2020 technisch te corrigeren (Brief, 2017) naar 4,6 Mton conform de afspraken in het convenant.

\section{Voorgaande convenanten}

In voorgaande convenanten waren ook doelen opgenomen over de energie-efficiëntie, het aandeel duurzame energie, de $\mathrm{CO}_{2}$-emissie van de teelt en de reductie van de $\mathrm{CO}_{2}$-emissie door warmtekrachtkoppeling (wkk). In de Meerjarenafspraak van 2014 zijn deze doelen weliswaar verlaten, maar blijven het pijlers voor $\mathrm{CO}_{2}$-emissiereductie en voor deze indicatoren blijft het daarom belangrijk om de ontwikkelingen in beeld te brengen.

\section{Programma Kas als Energiebron}

Om het doel in van de Meerjarenafspraak te bereiken, werken glastuinbouw en rijksoverheid samen in het programma Kas als Energiebron (KaE). De ambities van KaE zijn dat vanaf 2020 in nieuwe kassen op economisch rendabele wijze netto klimaatneutraal geproduceerd kan worden en dat dit in bestaande kassen met de helft van de fossiele brandstof ten opzichte van 2011 kan. Voor 2050 heeft $\mathrm{KaE}$ de ambitie dat de glastuinbouw een volledig duurzame en economisch rendabele energievoorziening zonder $\mathrm{CO}_{2}$-emissie heeft.

\section{$\mathrm{CO}_{2}$-emissie}

De $\mathrm{CO}_{2}$-emissie in de Meerjarenafspraak heeft betrekking op de absolute uitstoot van $\mathrm{CO}_{2}$. Deze wordt bepaald met de methode van het Intergovernmental Panel on Climate Change (IPCC-methode) en heeft het alleen betrekking op het fossiele brandstofverbruik van de glastuinbouw op locatie. In- en verkoop van energie (elektriciteit en warmte) tellen hierbij niet mee. In de energiemonitor wordt bij de $\mathrm{CO}_{2^{-}}$ emissie, voor een beter begrip en duiding, onderscheid gemaakt tussen totale $\mathrm{CO}_{2}$-emissie en $\mathrm{CO}_{2}$ emissie voor de teelt. Het verschil is de emissie die samenhangt met de verkoop van elektriciteit uit aardgasgestookte wkk. Het doel van de Meerjarenafspraak heeft betrekking op de totale $\mathrm{CO}_{2}$-emissie.

\section{Energie-efficiëntie}

De energie-efficiëntie is een relatieve indicator, gedefinieerd als het primair brandstofverbruik per geproduceerde eenheid (tuinbouw)product. Het primair brandstofverbruik is de fossiele brandstof die nodig is voor de productie van de energie-input, verminderd met de fossiele brandstof die elders wordt uitgespaard door energie-output van de glastuinbouw. Bij het primair brandstofverbruik worden naast de input van fossiele brandstof dus ook de overige energie-input en -output in beschouwing genomen. Het primair brandstofverbruik wordt vervolgens in relatie gebracht met de omvang van de fysieke tuinbouwproductie waarvoor de brandstof is ingezet. 
Aandeel duurzame energie

Het aandeel duurzame energie is net als de energie-efficiëntie een relatieve indicator. Het wordt uitgedrukt in procenten van het totale netto-energiegebruik van de glastuinbouw. Het totale nettoenergiegebruik en de hoeveelheid duurzame energie worden bepaald op basis van de energie-inhoud van de energie-input en -output.

Protocol

De definities van de indicatoren, de methodiek en de gebruikte bronnen voor de monitor zijn vastgelegd in het Protocol Energiemonitor Glastuinbouw (Van der Velden en Smit, 2017) en zijn in bijlage 1 op hoofdlijnen toegelicht. In het Protocol wordt onderscheid gemaakt tussen de conceptuele methodiek en de werkwijze. De werkwijze wijzigt in de loop der jaren, vooral door beschikbaarheid van databronnen en mutaties in omrekeningsfactoren. Daardoor wordt jaarlijks een update van het Protocol gepubliceerd met deze mutaties en verbeteringen in de werkwijze.

\section{$\mathrm{CO}_{2}$-emissieruimte}

In het Convenant $\mathrm{CO}_{2}$-emissieruimte binnen het $\mathrm{CO}_{2}$-sectorsysteem glastuinbouw is een totale $\mathrm{CO}_{2}$-emissieruimte (inclusief verkoop elektriciteit) van 6,2 Mton in 2020 afgesproken. De 6,2 Mton komt overeen met het doel in de Meerjarenafspraak. Boven deze emissieruimte dient er door de sector betaald te worden aan de overheid. Voor de uitvoering van dit convenant is het $\mathrm{CO}_{2}$ sectorsysteem voor de glastuinbouw ontwikkeld. Zoals eerder vermeld in dit hoofdstuk, is de $\mathrm{CO}_{2}$ emissieruimte voor 2020 in 2017 technisch gecorrigeerd naar 4,6 Mton.

\section{Energie Besparingssysteem Glastuinbouw}

Naast het $\mathrm{CO}_{2}$-sectosysteem heeft de glastuinbouwsector het Energie Besparingssysteem Glastuinbouw (EBG) ontwikkeld. Het EBG voorziet in een individuele prikkel voor glastuinbouwbedrijven om de $\mathrm{CO}_{2}$-emissie te reduceren.

\section{Energieakkoord}

In 2013 is het Energieakkoord voor duurzame groei gesloten. Hierin is voor de glastuinbouw vastgelegd dat in aanvulling op het huidige beleid wordt ingezet op een extra energiebesparing in 2020 van 11 PJ ten opzichte van 2011. Dit omvatte zo'n 10\% van het totale energiegebruik in de glastuinbouw in 2011. In de Energiemonitor van de Nederlandse glastuinbouw wordt deze energiebesparing niet gemonitord.

Ontwikkeling $\mathrm{CO}_{2}$-emissie

De $\mathrm{CO}_{2}$-emissie in de glastuinbouw wordt naast jaarlijkse verschillen in de buitentemperatuur beïnvloed door veranderingen van acht factoren. Deze factoren zijn: de omvang van de sector (areaal kassen), veranderingen in de energievoorziening (inkoop fossiele brandstof, warmte en elektriciteit; verkoop elektriciteit; gebruik (productie en inkoop) van duurzame energie), intensivering en extensivering van de teelt (toename en afname van de energievraag per $\mathrm{m}^{2}$ ) en energiebesparing (afname van de energievraag per $\mathrm{m}^{2}$ ).

\section{Areaal kassen}

Het areaal kassen is van invloed op de totale $\mathrm{CO}_{2}$-emissie van de sector. De ontwikkeling van het areaal is afhankelijk van de vraag naar de afzonderlijke Nederlandse glastuinbouwproducten en van de fysieke productie per $\mathrm{m}^{2}$ kas.

\section{Energievoorziening}

Door intensivering, extensivering en energiebesparing verandert de energievraag. Daarnaast is de wijze waarop in de energievraag wordt voorzien van invloed op de ontwikkeling van de $\mathrm{CO}_{2}$-missie van de glastuinbouw. Warmte uit aardgas via ketel is al lange tijd niet meer de belangrijkste energievoorziening. Door de tuinders wordt een mix ingezet van wkk, ketels, inkoop warmte en elektriciteit en duurzame energiebronnen. Ook wordt er elektriciteit en in geringe mate warmte verkocht.

Duurzame energiebronnen zijn hernieuwbaar en gaan niet samen met het verbruik van fossiele brandstof en primair brandstofverbruik. Voorbeelden van duurzame energiebronnen in de glastuinbouw zijn aardwarmte, zonne-energie en biobrandstof. Ook koopt de sector duurzame energie 
en warmte van derden in. Daarnaast is efficiëntere energieproductie mogelijk met technologie die meer nuttige energie (warmte en elektriciteit) haalt uit fossiele brandstof. Een voorbeeld hiervan is wkk van de tuinders en restwarmte. De duurzame en efficiëntere voorzieningen hebben zowel binnen als buiten de tuinbouw een positieve invloed op de $\mathrm{CO}_{2}$-emissie.

Intensivering en extensivering

De Nederlandse glastuinbouw kenmerkt zich door een hoge productie en dito kosten per $\mathrm{m}^{2}$ kas. Het gematigde klimaat met zachte winters en koele zomers is gunstig voor de teelt van glastuinbouwproducten. In de Nederlandse glastuinbouw is een continu proces van intensivering gaande. Intensivering is een economisch gedreven proces dat leidt tot een toename van de energiebehoefte. Voortdurende innovatie van kassen, teeltsystemen en andere technologische hulpmiddelen zijn vooral gericht op verdere optimalisatie van de teeltomstandigheden. Hiermee richt de sector zich op het jaarrond leveren van kwaliteitsproducten voor de topsegmenten van de internationale markt. Dit leidt tot meer gewassen met een grotere energiebehoefte maar ook tot toenemende productie in de winterperiode met groeilicht. Intensivering brengt hierdoor een gemiddeld grotere energievraag per $\mathrm{m}^{2}$ kas met zich mee.

Naast intensivering vinden er ontwikkelingen plaats waardoor er juist minder energie-intensieve gewassen worden geteeld en minder intensief wordt geteeld, bijvoorbeeld door verminderde vraag vanuit de markt naar energie-intensieve gewassen en/of stijging van de energiekosten. Door deze veranderingen in de sectorstructuur daalt het gemiddelde energiegebruik per $\mathrm{m}^{2}$ kas en is er extensivering.

\section{Energiebesparing}

Naast extensivering kan de energievraag per $\mathrm{m}^{2}$ kas ook verminderen door het gebruik van energiebesparende opties. Voorbeelden hiervan zijn nieuwe kassen, (extra) energieschermen, efficiëntere lampen, led-licht, gelijkstroom en energiezuinige teeltstrategieën zoals Het Nieuwe Telen (HNT). HNT is een innovatieve energiezuinige teeltstrategie voor regeling van het kasklimaat waarbij gebruik wordt gemaakt van natuur- en plantkundige kennis om de teelt optimaal te sturen qua temperatuur, vocht, $\mathrm{CO}_{2}$-niveau, licht en het gebruik van schermen. HNT is in ontwikkeling en staat sterk in de belangstelling.

Effecten $\mathrm{CO}_{2}$-emissie

Een onderzoek naar de effecten van intensivering, extensivering en energiebesparing op de $\mathrm{CO}_{2}$ emissie in de periode 2020-2015 door Wageningen Economic Research is in 2017 gepubliceerd (Van der Velden en Smit, 2017). Op de bevindingen wordt voortgebouwd in paragraaf 2.5.

\subsection{De Energiemonitor}

In de Energiemonitor van de Nederlandse Glastuinbouw wordt de ontwikkeling van de totale $\mathrm{CO}_{2}-$ emissie gekwantificeerd en geanalyseerd. Ook worden de achterliggende indicatoren $\mathrm{CO}_{2}$-emissie teelt, energie-efficiëntie en het aandeel duurzame energie gekwantificeerd en geanalyseerd. Als basis hiervoor wordt de energiebalans van de glastuinbouw opgesteld. De energiebalans omvat de energieinput en de energie-output van de sector. Daarnaast wordt de elektriciteitsbalans (inkoop, verkoop, productie en consumptie) globaal in kaart gebracht. Om de energie-efficiëntie te kunnen bepalen, wordt tenslotte ook de ontwikkeling van de fysieke productie van de glastuinbouw gekwantificeerd.

Deze rapportage bevat de definitieve resultaten tot en met 2015 en - op basis van de medio 2017 beschikbare informatie - de voorlopige resultaten van 2016. Door het gebruik van aanvullende en nieuwe databronnen zijn enkele eerder gepubliceerde resultaten over voorgaande jaren aangepast.

De ontwikkeling van de $\mathrm{CO}_{2}$-emissie, de achterliggende indicatoren en de factoren van invloed op de ontwikkeling komen aan bod in hoofdstuk 2. Hoofdstuk 3 gaat in op het gebruik van duurzame energie. Warmtekrachtkoppeling, warmte-inkoop en de globale elektriciteitsbalans van de glastuinbouw staan centraal in hoofdstuk 4 . Ten slotte volgen in hoofdstuk 5 de conclusies. 


\section{Energie-indicatoren}

\section{$2.1 \quad$ Inleiding}

In de volgende paragraaf wordt de $\mathrm{CO}_{2}$-emissie behandeld. Vervolgens komen de energie-efficiëntie en het aandeel duurzame energie aan bod. In de laatste twee paragrafen komt de analyse van de oorzaken van de ontwikkeling van de totale $\mathrm{CO}_{2}$-emissie en de ontwikkeling van de energiekosten en het energiegebruik aan bod.

\section{$2.2 \quad \mathrm{CO}_{2}$-emissie}

Totaal en teelt

$\mathrm{Bij}$ de $\mathrm{CO}_{2}$-emissie van de glastuinbouw worden de totale $\mathrm{CO}_{2}$-emissie en de $\mathrm{CO}_{2}$-emissie voor de teelt onderscheiden. Het verschil is de emissie die samenhangt met de verkoop van elektriciteit uit aardgasgestookte wkk.

In 2016 daalde de totale $\mathrm{CO}_{2}$-emissie met 0,2 Mton naar 5,6 Mton (figuur 2.1). Dit volgde na een sterke daling van 2,4 Mton in de periode 2010-2014 en een lichte toename van 0,1 Mton in 2015. De totale $\mathrm{CO}_{2}$-emissie in 2016 ligt daarmee 0,6 Mton (9\%) onder het oorspronkelijke doel van 6,2 Mton voor 2020 in de Meerjarenafspraak. In vergelijking met het $\mathrm{CO}_{2}$-doel voor 2020 na technische correctie (4,6 Mton) lag de werkelijke $\mathrm{CO}_{2}$-emissie in 2016 hoger en dient de emissie met nog 1,0 Mton te worden gereduceerd. De totale $\mathrm{CO}_{2}$-emissie lag in 2016 1,2 Mton (18\%) lager in vergelijking met 1990 (6,8 Mton).

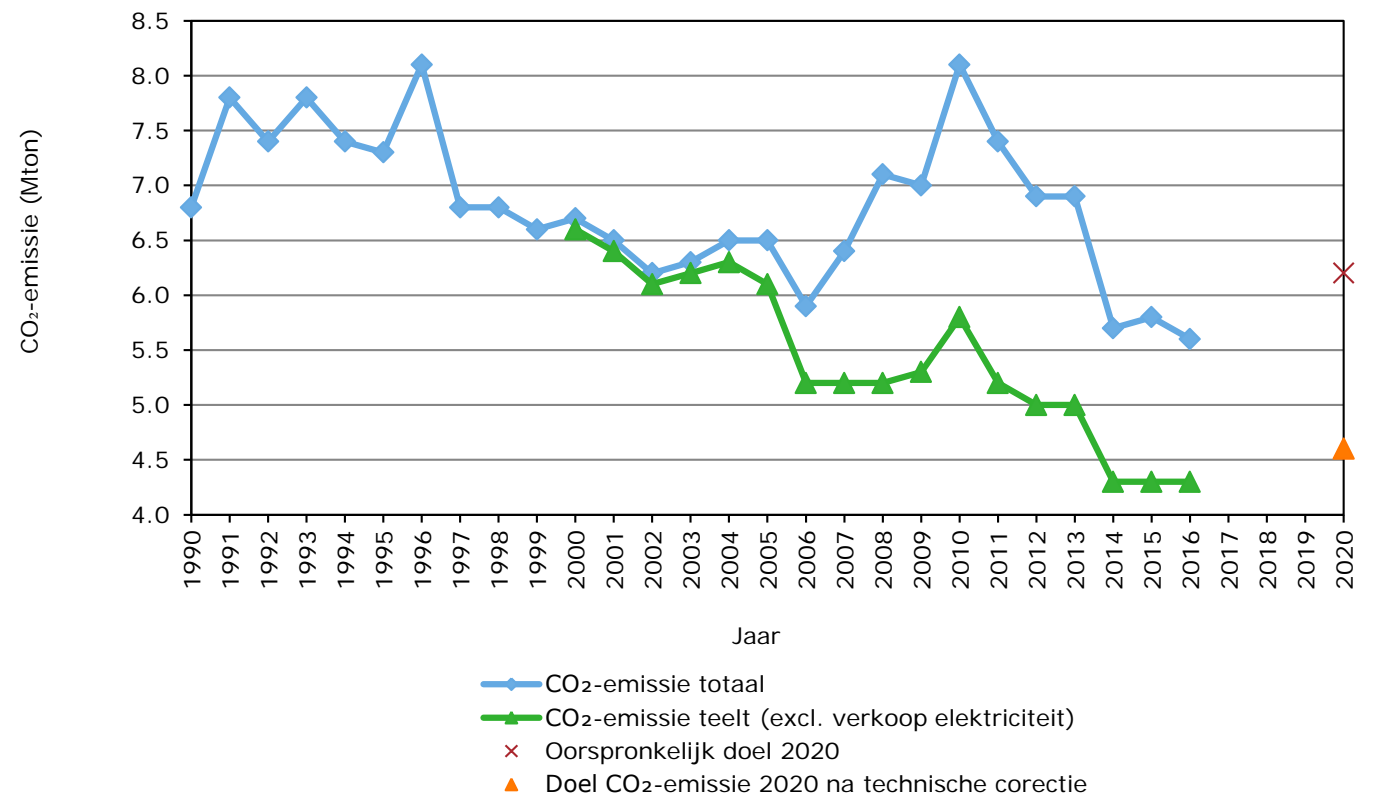

Figuur 2.1 $\mathrm{CO}_{2}$-emissie vanuit de glastuinbouw per jaar a)

a) Cijfers 2016 voorlopig.

De $\mathrm{CO}_{2}$-emissie voor de teelt bleef in de jaren na 2014 met 4,3 Mton op een gelijk niveau (figuur 2.1) en lag in 2016 2,5 Mton (37\%) onder de emissie van 1990. Het verschil tussen de totale $\mathrm{CO}_{2}$-emissie 
en de $\mathrm{CO}_{2}$-emissie voor de teelt is sinds 2010 kleiner geworden en bedroeg in 2016 1,3 Mton. Dit kleinere verschil kwam door vermindering van de verkoop van elektriciteit vanuit wkk

(paragraaf 4.2.2).

Temperatuurcorrectie

De $\mathrm{CO}_{2}$-emissie wordt conform de definitie niet gecorrigeerd voor buitentemperatuur. De jaren 2014, 2015 en 2016 waren relatief warm maar 2016 was minder warm dan 2014 en 2015 . Als de $\mathrm{CO}_{2}$-emissie wel gecorrigeerd zou worden voor de buitentemperatuur dan zou de totale $\mathrm{CO}_{2}$-emissie in deze jaren hoger komen te liggen. De $\mathrm{CO}_{2}$-emissie in 2016 wordt dan 5,7 Mton en het verschil met de $\mathrm{CO}_{2}$-emissieruimte na technische correctie wordt dan 1,1 Mton.

$\mathrm{Na}$ temperatuurcorrectie zou de $\mathrm{CO}_{2}$-emissie in de periode 2014-2016 met 0,3 Mton zijn gedaald. Dit is meer dan de daling voor temperatuurcorrectie. Dit betekent dat na de sterke daling van de $\mathrm{CO}_{2}-$ emissie in de periode 2010-2014 ook in de jaren daarna reductie heeft plaatsgevonden.

$\mathrm{CO}_{2}$-emissie Nederland

Voor Nederland als geheel kwam de $\mathrm{CO}_{2}$-emissie in 2016 uit op 187,0 Mton (CBS Statline, bijlage 2). Dit is $9 \%$ meer dan in 1990. In de glastuinbouw ligt de totale $\mathrm{CO}_{2}$-emissie in $201618 \%$ en de $\mathrm{CO}_{2}$ emissie voor de teelt 37\% onder het niveau van 1990. De glastuinbouw doet bij het terugdringen van de $\mathrm{CO}_{2}$-emissie dus beter dan de landelijke ontwikkeling waarbij de sector een substantiële hoeveelheid elektriciteit met wkk op aardgas is gaan produceren en verkopen. De emissie voor de elektriciteitsproductie maakt geen deel uit van de emissie voor de teelt. De emissie voor de teelt is dan ook sterker gedaald.

Warmtekrachtkoppeling

De glastuinbouw produceerde in 2016 ruim 9 miljard kWh elektriciteit met aardgas-wkk (hoofdstuk 4). Dit is $23 \%$ minder dan in 2011, het jaar met de hoogste elektriciteitsproductie. Met de productie in 2016 werd op basis van het primair brandstofverbruik op nationaal niveau 1,8 $\mathrm{Mton} \mathrm{CO}_{2}$-emissie vermeden. Deze vermeden $\mathrm{CO}_{2}$-emissie kwam voort uit een extra aardgasverbruik in de glastuinbouw door wkk van 2,6 miljard $\mathrm{m}^{3}$, een vermeden brandstofverbruik in elektriciteitscentrales van 2,4 miljard $\mathrm{m}^{3}$ aardgasequivalenten en een aardgasbesparing door de warmtebenutting in de glastuinbouw van 1,2 miljard $\mathrm{m}^{3}$.

\subsection{Energie-efficiëntie}

Na de verslechtering met 1 procentpunt in 2015 liet de energie-efficiëntie in 2016 weer een verbetering zien met 1 procentpunt. In 2016 bedroeg de energie-efficiëntie 41\% ten opzichte van 1990 (figuur 2.2 en bijlage 2). De glastuinbouw gebruikte in 2016 dus 59\% minder primair brandstof per eenheid product dan in 1990. De verbetering van de energie-efficiëntie in 2016 kwam door een daling van het primair brandstofverbruik per $\mathrm{m}^{2}$ met ruim $1 \%$ en een toename van de fysieke productie per $\mathrm{m}^{2}$ met $0,5 \%$.

Over een langere periode bezien is de energie-efficiëntie in de jaren 2005-2008 sterk verbeterd ( 23 procentpunt). In de jaren 2008-2016 is de verbetering met 3 procentpunt beduidend minder geweest.

Primair brandstof

Het primair brandstofverbruik per $\mathrm{m}^{2}$ (figuur 2.3 en bijlage 2) daalde in de periode 1990-2008. De daling was het sterkst in de jaren 2005-2008. Dit kwam vooral door de sterke groei van het gebruik van wkk en het nuttige gebruik van de vrijkomende warmte en $\mathrm{CO}_{2}$ bij deze vorm van elektriciteitsproductie (hoofdstuk 4). In de periode 2008-2016 was het primair brandstofverbruik per $\mathrm{m}^{2}$ met 3\% toegenomen. Dit kwam vooral door vermindering van de elektriciteitsverkoop vanuit de wkk, door de toename van het elektriciteitsconsumptie voor groeilicht (paragraaf 2.6) en door energiebesparing (paragraaf 2.5). 


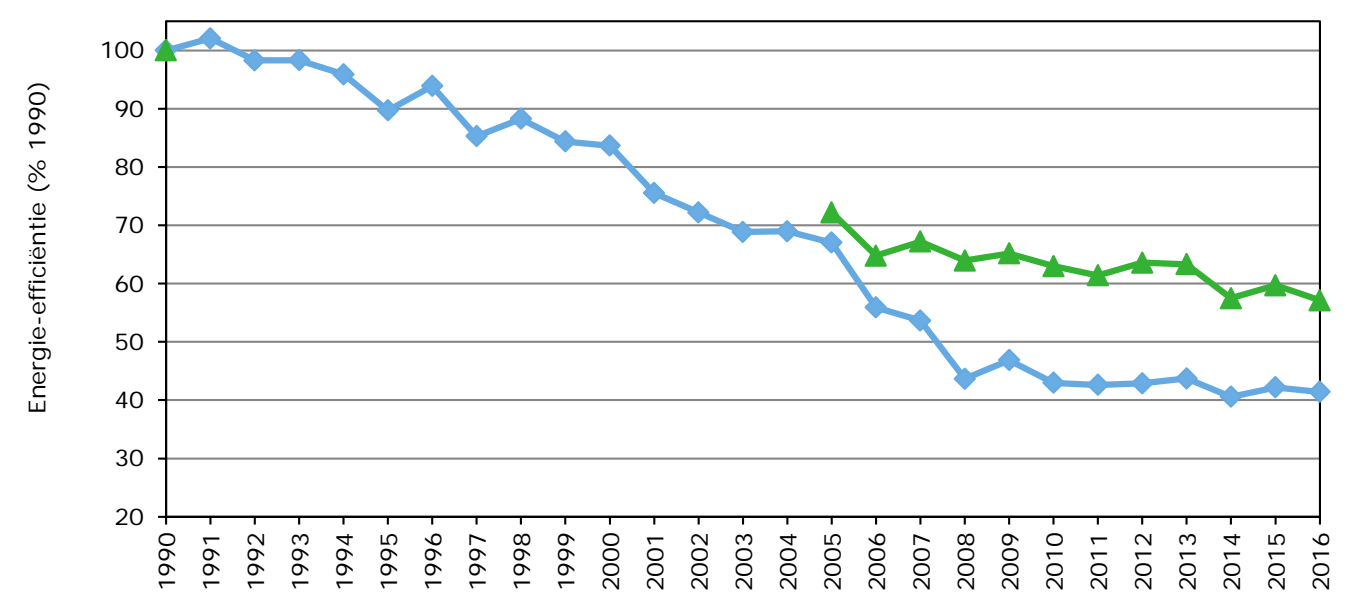

Jaar

$\multimap$ Werkelijke ontwikkeling _ _ _ Fictieve ontwikkeling zonder wk-tuinder

Figuur 2.2 Energie-efficiëntie in de productieglastuinbouw per jaar met en zonder wkk a) a) Cijfers 2016 voorlopig.

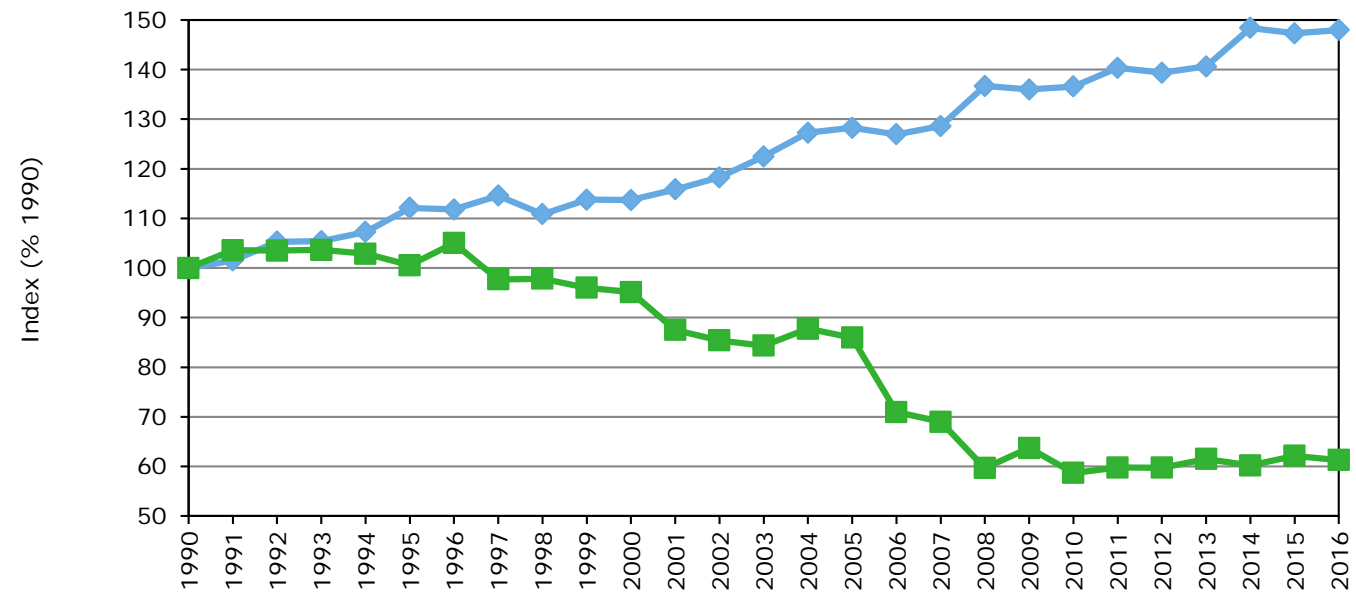

Jaar

$\longrightarrow$ Index fysieke productie per $\mathrm{m}^{2} \quad$ Index primair brandstof per $\mathrm{m}^{2}$

Figuur 2.3 Fysieke productie en primair brandstofverbruik in de productieglastuinbouw per $\mathrm{m}^{2}$ kas a) a) Cijfers 2016 voorlopig.

Fysieke productie

De fysieke productie per $\mathrm{m}^{2}$ vertoont vanaf 1990 een stijgende trend; ook hier zijn er verschillen tussen de jaren (figuur 2.3 en bijlage 2). Over de gehele periode 1990-2016 steeg de fysieke productie per $\mathrm{m}^{2}$ met $48 \%$. Dat is gemiddeld 1,5\% per jaar. In de periode 2008-2016 was dit slechts $1,0 \%$ per jaar en vlakte de ontwikkeling dus wat af. De sterkste toename zat daarbij in 2014 maar daarna bleef de fysieke productie vrijwel ongewijzigd. In 2016 nam ondanks minder licht de fysieke productie iets toe. 


\section{Effect warmtekrachtkoppeling}

Het gebruik van wkk heeft een positief effect op de energie-efficiëntie, omdat zowel de elektriciteit als de vrijkomende warmte nuttig worden gebruikt. In de periode 2008-2013 lag dit positieve effect op ongeveer 20 procentpunten in vergelijking met een situatie zonder wkk (figuur 2.2). In 2016 was dit effect teruggelopen tot 15 procentpunten. De vermindering hangt samen met de verminderde elektriciteitsproductie door wkk voor de verkoop door een ongunstige spark spread (het verschil tussen de aardgasprijs (inkoop) en de elektriciteitsprijs (verkoop)). Uit figuur 2.2 blijkt ook dat de energie-efficiëntie zonder wk geleidelijk verder verbeterd, maar minder sterk dan met wk. Naast het energetische aspect komt er door het gebruik van wkk per eenheid warmte meer $\mathrm{CO}_{2}$ beschikbaar en dit heeft een positieve invloed op de fysieke productie. De verwachting is dat in de nabije toekomst de elektriciteitsverkoop vanuit wkk verder zal dalen, waardoor de ontwikkeling van de energie-efficiëntie onder druk blijft staan.

\subsection{Aandeel duurzame energie}

Het aandeel duurzame energie verbeterde in 2016 wederom. Het groeide van 4,9 naar 5,5\%, een toename van 0,6 procentpunt (figuur 2.4). Het absolute gebruik van duurzame energie nam in 2016 toe van 4,8 naar 5,4 PJ. Dit is een toename met $11 \%$. Vanaf 2010 is het absolute gebruik van duurzame energie ruim verdubbeld. In 2016 was de toename van het aandeel groter dan die van de absolute hoeveelheid duurzame energie. Dit kwam doordat het totaal energiegebruik in 2016 iets daalde (bijlage 2). Het aandeel duurzame energie en het absolute gebruik groeiden in 2016 weliswaar, maar wel minder in 2014 en 2015.

Voor Nederland als geheel bedroeg het aandeel duurzame energie in 2016 6,0\% (CBS, Statline, bijlage 2). Bij duurzame energie loopt de glastuinbouw dus 0,5 procentpunt achter op het landelijke aandeel. Het gebruik van duurzame energie groeide de laatste jaren in de glastuinbouw wel sterker. In 2010 bedroeg de achterstand nog 2 procentpunten.

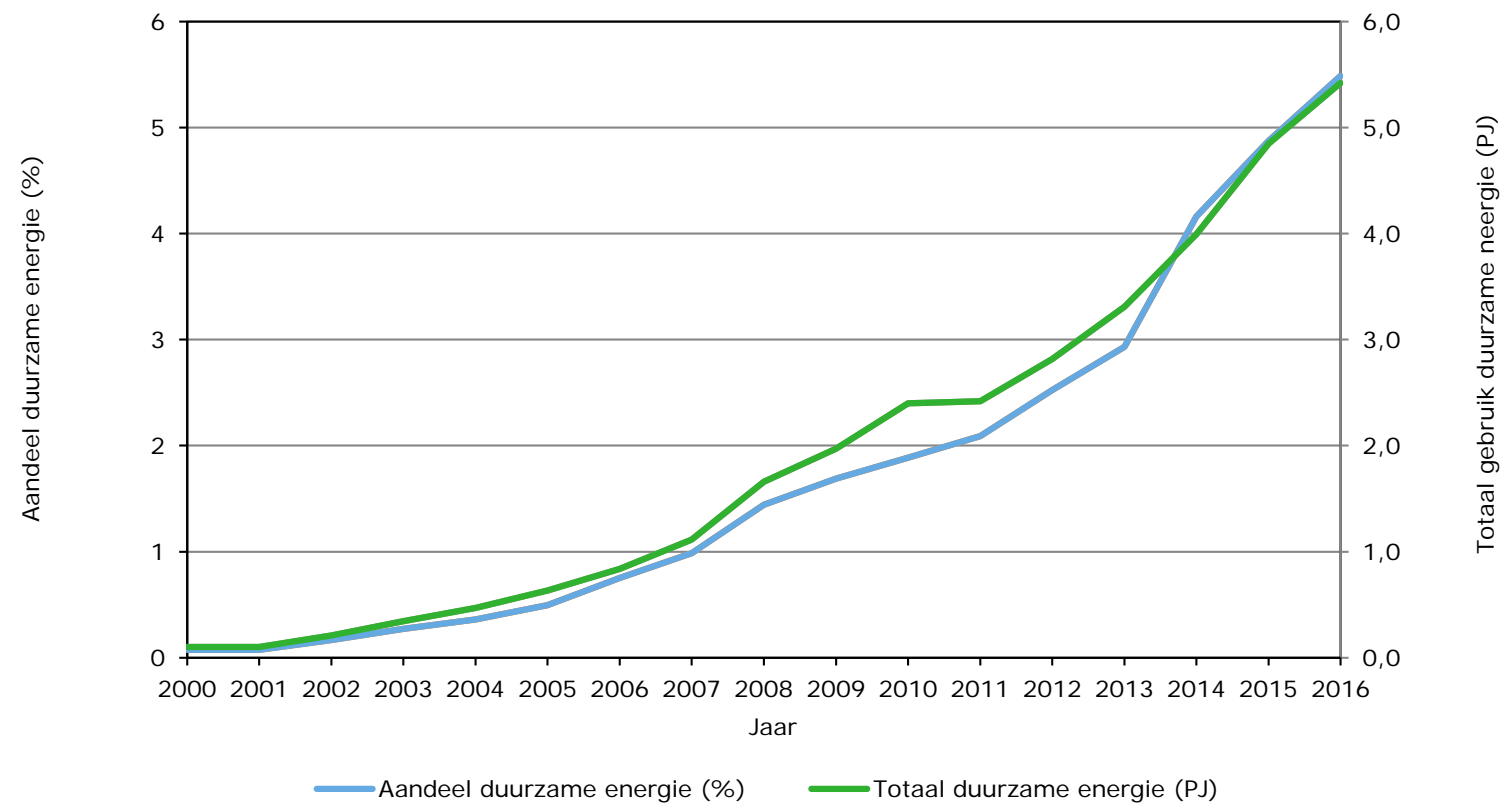

Figuur 2.4 Aandeel duurzame energie in de glastuinbouw per jaar a)

a) Cijfers 2016 voorlopig.

Door de glastuinbouw toegepaste duurzame energie werd voor 77\% door de sector zelf geproduceerd en voor $23 \%$ ingekocht. Van de toegepaste warmte werd $96 \%$ zelf geproduceerd. Van de toegepaste 
elektriciteit werd $98 \%$ ingekocht. De hoeveelheid duurzame energie die door de glastuinbouw wordt verkocht aan afnemers buiten de sector is beperkt (hoofdstuk 3).

Het gebruik van duurzame energie had in het jaar 2016 een positief effect op de $\mathrm{CO}_{2}$-emissie op sectorniveau van 0,25 Mton. Op de energie-efficiëntie was het effect 2 procentpunten (paragraaf 3.4).

\subsection{Analyse ontwikkeling $\mathrm{CO}_{2}$-emissie}

Inleiding

In de periode 2010-2016 daalde de totale $\mathrm{CO}_{2}$-emissie van de glastuinbouw met 2,48 Mton (31\%). Deze daling was een trendbreuk met de voorafgaande periode. In deze paragraaf worden de achtergronden van de ontwikkelingen in de periode 2010-2016 geanalyseerd.

Naast de invloed van de buitentemperatuur wordt de ontwikkeling van de totale $\mathrm{CO}_{2}$-emissie bepaald door onderstaande factoren die achtereenvolgens worden behandeld:

1. Areaal glastuinbouw

2. Verkoop elektriciteit

3. Gebruik duurzame energie

4. Gebruik warmte van derden

5. Inkoop elektriciteit

6. Intensivering en extensivering

7. Energiebesparing

Buitentemperatuur

Het jaar 2016 was relatief warm en 2010 relatief koud. Als de $\mathrm{CO}_{2}$-emissie voor de buitentemperatuur wordt gecorrigeerd, dan bedraagt de daling in de periode 2010-2016 2,17 Mton in plaats van 2,48 Mton. Deze daling van 2,17 Mton is het vertrekpunt voor de analyse van de effecten van de overige invloedsfactoren (tabel 2.1).

Analyse

De analyse van de effecten van de invloedsfactoren gaat na temperatuurcorrectie verder met het effect van het areaal en de veranderingen van de energie-input en -output van de glastuinbouw die betrekking hebben op de doelvariabele $\mathrm{CO}_{2}$-emissie c.q. aardgasverbruik. Van deze 5 factoren is kwantitatieve informatie beschikbaar. Daarna komen de intensivering, extensivering en energiebesparing, ofwel het energiegebruik per $\mathrm{m}^{2}$ aan bod. Over deze ontwikkelingen binnen de glastuinbouw was weinig kwantitatieve informatie beschikbaar. Het gezamenlijk effect werd daarom als saldo gekwantificeerd. Het effect op de $\mathrm{CO}_{2}$-emissie van deze drie factoren in een separaat onderzoek gekwantificeerd over de periode 2010-2015 (Van der Velden en Smit, 2017).

\section{Areaal glastuinbouw}

Het areaal glastuinbouw daalde in de periode 2010-2016 van 10.307 naar 9.278 ha. Deze krimp van $10 \%$ leidde tot een daling van de $\mathrm{CO}_{2}$-emissie van 0,52 Mton. Dit effect is bepaald op basis van de jaarlijkse daling van het areaal en van de gemiddelde $\mathrm{CO}_{2}$-emissie per $\mathrm{m}^{2}$ kas voor de teelt (exclusief verkoop elektriciteit) van het voorafgaande jaar.

2. Verkoop elektriciteit

Met wkk produceren tuinders elektriciteit en warmte. Een deel van de geproduceerde elektriciteit wordt door de glastuinbouw zelf gebruikt en een deel wordt verkocht. De eigen consumptie is toegenomen. Dit kwam door de intensivering en wordt in beschouwing genomen bij punt 6 . De verkoop van elektriciteit daalde in de periode 2010-2016 van 8,4 naar 4,9 miljard kWh. Dit komt overeen met een reductie van de $\mathrm{CO}_{2}$-emissie van 0,96 Mton. Bij de bepaling van deze reductie is rekening gehouden met een lager aardgasverbruik in wkk en een hoger verbruik in de ketels. 
Tabel 2.1 Effect van de invloedsfactoren op de totale $\mathrm{CO}_{2}$-emissie van de glastuinbouw voor de periode 2010-2016 (Mton)

\begin{tabular}{|c|c|c|c|c|c|c|}
\hline \multirow[t]{2}{*}{ Invloedsfactoren } & \multirow[t]{2}{*}{ Eenheid } & \multirow[t]{2}{*}{2010} & \multirow[t]{2}{*}{2016} & \multirow[t]{2}{*}{$\begin{array}{r}\text { Verschil } \\
2010-2016\end{array}$} & \multicolumn{2}{|c|}{$\begin{array}{c}\text { Effect } \mathrm{CO}_{2} \text {-emissie } \\
2010-2016\end{array}$} \\
\hline & & & & & Mton & $\%$ \\
\hline Verkoop elektriciteit & miljard kWh & 8,4 & 4,9 & $-3,5$ & $-0,96$ & 44 \\
\hline Duurzame energie & PJ & 2,4 & 5,4 & $+3,0$ & $-0,17$ & 8 \\
\hline Inkoop elektriciteit (fossiel) & miljard kWh & 2,0 & 2,4 & $+0,4$ & $-0,10$ & 5 \\
\hline Subtotaal & & & & & $-1,67$ & 77 \\
\hline $\begin{array}{l}\text { Energiegebruik per } \mathrm{m}^{2} \text { kas } \\
\text { (intensivering, extensivering en } \\
\text { energiebesparing) }\end{array}$ & & & & & $-0,50$ & 23 \\
\hline
\end{tabular}

\section{Gebruik duurzame energie}

Het gebruik van duurzame energie (productie en inkoop) steeg in de periode 2010-2016 van 2,4 naar 5,4 PJ. Duurzame warmte vervangt warmte uit aardgasgestookte ketels en wkk waardoor minder aardgas wordt verbruikt. Voor duurzame elektriciteit wordt evenals bij inkoop van niet duurzame elektriciteit (punt 5) verondersteld dat dit niet behoeft te worden geproduceerd met wkk en er dus minder aardgas wordt gebruikt. De toename van het gebruik van duurzame energie resulteert in een verlaging van de $\mathrm{CO}_{2}$-emissie met 0,17 Mton.

4. Gebruik warmte van derden

Het gebruik van warmte van derden betreft de inkoop van restwarmte van elektriciteitscentrales en industrieën en de inkoop van warmte van wk-installaties van energiebedrijven. De inkoop van warmte (exclusief inkoop van duurzame warmte) nam in de periode 2010-2016 af van 5,3 naar 3,7 PJ. Hierdoor was meer aardgas nodig om in de warmtevraag te voorzien en nam de $\mathrm{CO}_{2}$-emissie met 0,09 Mton toe.

5. Inkoop elektriciteit

De inkoop van elektriciteit (exclusief inkoop van duurzame elektriciteit) nam toe van 2,0 naar

2,4 miljard kWh. Hierdoor hoefde er minder elektriciteit te worden geproduceerd met de wkk en nam het aardgasverbruik af. Het effect op de $\mathrm{CO}_{2}$-emissie is een daling met 0,10 Mton. De toename van de inkoop kan voortkomen uit een grotere consumptie, dit betreft intensivering en behoort bij punt 6 .

Subtotaal

Het totaaleffect van de vijf voornoemde invloedsfactoren op de totale $\mathrm{CO}_{2}$-emissie in de periode 20102016 bedraagt 1,67 Mton (tabel 2.1). Dit verklaart 77\% van de reductie van 2,17 Mton. Het saldo van 0,50 Mton $(2,17-1,67)$ is het gezamenlijk effect van intensivering, extensivering en energiebesparing, ofwel het energiegebruik per $\mathrm{m}^{2}$. Dit totaal effect is groter dan in de periode $2010-2015(0,41$ Mton).

6. Intensivering en extensivering

Intensivering en extensivering vinden naast elkaar plaats. Door intensivering neemt de energievraag en de $\mathrm{CO}_{2}$-emissie toe en door extensivering nemen deze af.

Intensivering uit zich in groei van het areaal gewassen met een hogere energiebehoefte, meer belichting, meer $\mathrm{CO}_{2}$-dosering, enzovoort. Hierdoor nemen de gemiddelde energievraag en de gemiddelde $\mathrm{CO}_{2}$-emissie per $\mathrm{m}^{2}$ kas in de sector toe.

In de periode 2010-2016 is het areaal kassen met ruim 1.000 ha afgenomen. Deze krimp zat voor een groot deel bij de energie-intensieve gewassen paprika, komkommer, roos en groene potplanten. Naast intensivering is er dus ook extensivering. Extensivering resulteert in een daling van het gemiddeld energiegebruik en $\mathrm{CO}_{2}$-emissie per $\mathrm{m}^{2}$ kas in de sector. 


\section{Energiebesparing}

De energievraag kan worden verminderd door het gebruik van energiezuinige teeltstrategieën en andere energiebesparende opties (paragraaf 1.2). Voorbeelden van energiezuinige teeltstrategieën zijn extra schermen en een langere gebruiksduur van de schermen, selectiever verwarmen en selectiever ventileren. Dit zijn allen elementen van Het Nieuwe Telen (HNT). Voorbeelden van andere opties zijn nieuwe kassen, efficiëntere lampen, isolatie, led-licht en gelijkstroom.

HNT is een innovatieve energiezuinige regelstrategie van het kasklimaat. Het maakt gebruik van natuur- en plantkundige kennis om de teelt optimaal te sturen in onder meer temperatuur, vocht, $\mathrm{CO}_{2}$-niveau, licht en schermen. Bij de tuinders staat HNT sterk in de belangstelling, mede omdat dit een positieve invloed op de omvang en de kwaliteit van de productie kan hebben (Buurma et al., 2015). HNT is vooral kennistoepassing en gaat niet gepaard met grote investeringen.

Saldo intensivering, extensivering en energiebesparing Het saldo van de drie factoren intensivering, extensivering en energiebesparing, ofwel de verandering energiegebruik per $\mathrm{m}^{2}$ kas (tabel 2.1), komt overeen met de daling van de $\mathrm{CO}_{2}$-emissie in de periode 2010-2016 met 0,50 Mton. Dit betekent dat het effect van extensivering en energiebesparing in deze periode groter was dan het effect van intensivering.

\section{Periode 2010-2015}

Het saldo van de drie factoren intensivering, extensivering en energiebesparing bedroeg in de periode 2010-2015 0,41 Mton. In 2016 is dit saldo dus toegenomen. In een separaat onderzoek zijn de effecten van intensivering, extensivering en energiebesparing op de $\mathrm{CO}_{2}$-emissie van glastuinbouw in de periode 2020-2015 gekwantificeerd (Van der Velden en Smit, 2017). Hieruit bleek dat door intensivering de $\mathrm{CO}_{2}$-emissie van de glastuinbouw in de periode 2010-2015 toenam met 0,28 tot 0,40 Mton. Door extensivering daalde de $\mathrm{CO}_{2}$-emissie met 0,13 Mton. Door energiebesparing (vraagreductie) daalde de jaarlijkse $\mathrm{CO}_{2}$-emissie met 0,5 tot $0,7 \mathrm{Mton}$. Dit is circa $30 \%$ van de totale reductie van de $\mathrm{CO}_{2}$-emissie in de glastuinbouw na temperatuurcorrectie van 2,0 Mton in de periode 2010-2015.

Ontwikkeling 2016

Over 2016 is een uitsplitsing van het saldo intensivering, extensivering en energiebesparing niet beschikbaar. Kwalitatief kan er wel het volgende over worden gezegd. De intensivering betrof vooral de teelt van meer energie-intensieve gewassen en belichting. Beiden hebben zich in 2016 verder ontwikkeld waardoor het effect van intensivering op de $\mathrm{CO}_{2}$-emssie is toegenomen. De extensivering is verminderd, omdat de krimp van het areaal met intensive gewassen is verminderd. Uit de voorgaande twee ontwikkelingen in combinatie met het grotere totaal saldo voor intensivering, extensivering en energiebesparing kan geconcludeerd worden dat het effect van energiebesparing op de $\mathrm{CO}_{2}$-emissie in 2016 verder is toegenomen, ondanks de verdere daling van de netto energiekosten.

\subsection{Energiekosten en energievraag}

\section{Energiekosten}

De energiekosten van de glastuinbouw worden in sterke mate bepaald door de inzet van wkk. Enerzijds wordt er extra aardgas ingekocht, anderzijds zijn vermeden kosten voor de inkoop van elektriciteit en opbrengsten voor de elektriciteit die wordt verkocht. In de periode 2007-2010 namen door de sterke groei van het wkk-park in de glastuinbouw - zowel de kosten voor de inkoop als de opbrengsten voor de vermeden inkoop en door de verkoop toe (figuur 2.5). Door de gunstige spark spread namen de netto-energiekosten per saldo af. Tegenover de daling van de netto-energiekosten staan wel hogere kapitaalkosten (afschrijving en rente) en onderhoudskosten van de wkk.

In de periode 2010-2013 stegen de netto-energiekosten met 35\% door hogere aardgasprijzen en teruglopende opbrengsten uit de verkoop van elektriciteit. Na 2013 daalden de netto-energiekosten. Dit werd veroorzaakt door dalende inkoopprijzen voor aardgas en elektriciteit. Bovendien werd er energiebesparing gerealiseerd en waren dit relatief warme jaren, waardoor de energievraag minder groot was. Ook werd er minder elektriciteit verkocht (paragraaf 4.4). Dit leidde ook tot een kortere 
gebruiksduur van wkk (paragraaf 4.4). Dit alles kwam tot uiting in dalende kosten voor energie-inkoop en dalende opbrengsten uit energieverkoop. Per saldo waren de netto energiekosten in 2016 lager dan in 2010 .

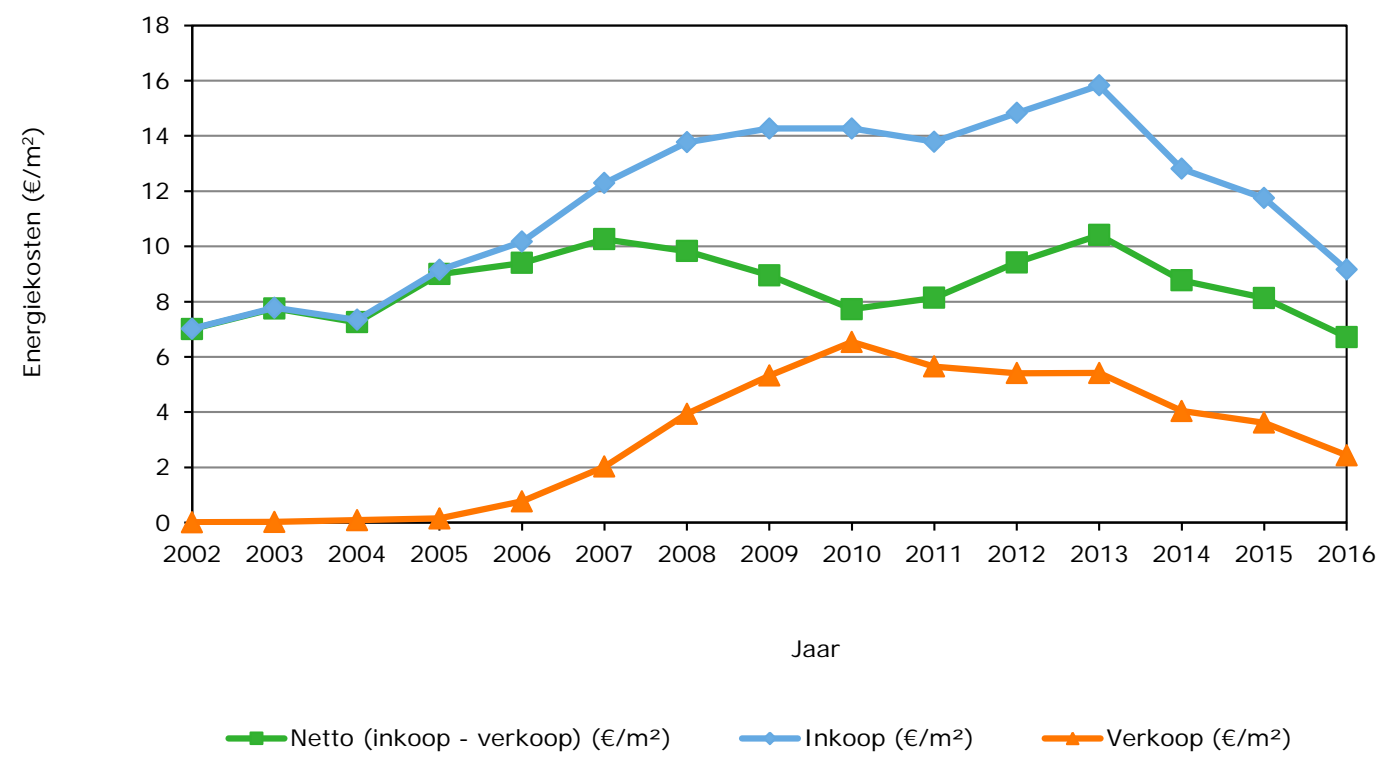

Figuur 2.5 Gemiddelde energiekosten glastuinbouw $\left(€ / \mathrm{m}^{2}\right)$ a)

a) Cijfers 2016 voorlopig.

Bron: Bedrijveninformatienet van Wageningen Economic Research.

\section{Energiegebruik}

Het totale energiegebruik van de glastuinbouw daalde in de periode 2010-2016 met 22\% van 127,1 naar 98,8 PJ (bijlage 1). Deze ontwikkeling ging samen met toenemende energievraag door intensivering, vermindering van de energievraag door extensivering en energiebesparing, de omvang van de sector (ha) en verschillen in buitentemperatuur tussen de jaren (paragraaf 2.5).

De energievraag wordt in beginsel niet beïnvloed door de energievoorziening of de herkomst van de energie (fossiel of duurzaam). Door uit te gaan van het voor buitentemperatuur gecorrigeerde energiegebruik per $\mathrm{m}^{2}$ hebben veranderingen in areaal en schommelingen in de buitentemperatuur geen invloed op de berekeningen en resteert de invloed van intensivering, extensivering en energiebesparing.

Energiegebruik per $\mathrm{m}^{2}$

Uit figuur 2.6 blijkt dat het gemiddelde energiegebruik per $\mathrm{m}^{2}$ gecorrigeerd voor de buitentemperatuur over de gehele periode 2000-2016 met 24\% daalde. De daling kwam in de periode 2000-2006 uit op $21 \%$ en in de periode $2010-2016$ op $9 \%$. In de tussenliggende periode $2006-2010$ nam het energieverbruik per $\mathrm{m}^{2}$ met $6 \%$ toe.

Warmte en elektriciteit

Het energiegebruik per $\mathrm{m}^{2}$ gecorrigeerd voor de buitentemperatuur is in figuur 2.5 vanaf 2006 opgesplitst in warmte en elektriciteit. Over de gehele periode 2006-2016 nam de warmteconsumptie met $21 \%$ af. De daling in de warmteconsumptie is voor een belangrijk deel gecompenseerd door groei van de elektriciteitsconsumptie $(+84 \%)$. De groei van de elektriciteitsconsumptie komt vooral door intensivering in de vorm van groeilicht. Daarnaast doen het gebruik van efficiëntere en duurzame energiebronnen, mechanisatie, automatisering en verdere optimalisatie van het kasklimaat de elektriciteitsconsumptie toenemen (Van der Velden en Smit, 2013). In 2016 bestond circa 70\% van het totale energiegebruik uit warmte en circa 30\% uit elektriciteit. In 2006 was dat $84 \%$ en $16 \%$. Ondanks verdere intensivering $\left(\mathrm{W}_{\mathrm{e}} / \mathrm{m}^{2}\right)$ van de belichting lijkt vanaf 2013 elektriciteitsconsumptie per $\mathrm{m}^{2}$ minder toe te nemen (paragraaf 4.4). Dit kwam door veranderingen in de sectorstructuur; het areaal met belichting bij tomaat nam toe en het areaal sierteelt met belichting nam af. 


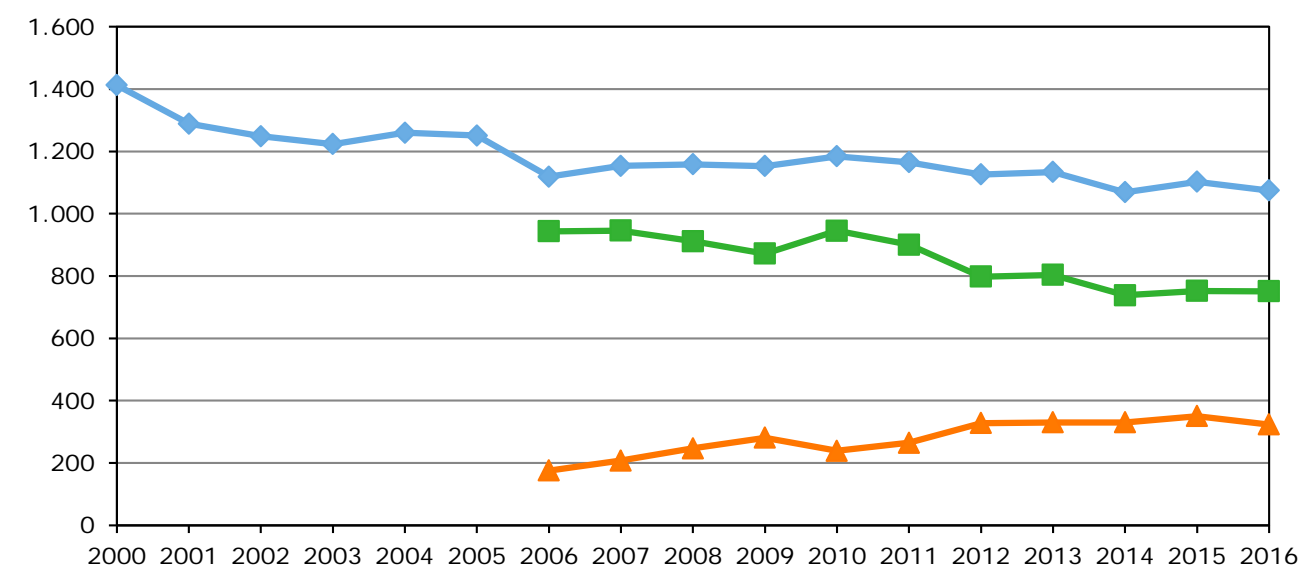

Jaar

$$
\longrightarrow \text { Energie totaal }\left(\mathrm{MJ} / \mathrm{m}^{2}\right) \quad \text { Warmte }\left(\mathrm{MJ} / \mathrm{m}^{2}\right) \quad \text { Elektriciteit }\left(\mathrm{MJ} / \mathrm{m}^{2}\right)
$$

Figuur 2.6 Energiegebruik per $\mathrm{m}^{2}$ gecorrigeerd voor de buitentemperatuur a) a) Cijfers 2016 voorlopig. 


\section{Duurzame energie}

\section{$3.1 \quad$ Inleiding}

Door de glastuinbouw wordt duurzame energie geproduceerd, ingekocht, verkocht en toegepast. Bij het aandeel duurzaam (paragraaf 2.4) telt alleen het daadwerkelijke gebruik mee. Dit is de inkoop plus de productie minus de verkoop aan afnemers buiten de sector.

In de volgende paragrafen komen achtereenvolgens de toepassing van duurzame energie, de ontwikkeling, de bedrijfsstructuur, de bijdrage aan de $\mathrm{CO}_{2}$-emissiereductie en de inkoop van externe $\mathrm{CO}_{2}$ aan de orde. Externe $\mathrm{CO}_{2}$ is geen duurzame energie, maar is vaak nodig om het gebruik van duurzame warmte in de glastuinbouw mogelijk te maken.

\subsection{Vormen van duurzame energie}

\subsubsection{Toepassing}

De Nederlandse glastuinbouw paste in 2016 zes vormen van duurzame energie toe (figuren 3.1, 3.2 en tabel 3.1). Aardwarmte was de voornaamste bron. Daarna volgden inkoop duurzame elektriciteit, zonne-energie, biobrandstoffen, inkoop duurzame warmte en inkoop duurzaam gas.

Het totale gebruik van duurzame energie groeide in 2016. Deze groei was het saldo van ingebruikname nieuwe projecten, aanpassing van bestaande projecten en projectbeëindiging. De groei zat ook in 2016 vooral bij aardwarmte en inkoop duurzame elektriciteit. Totaal werd er door de glastuinbouw 5,4 PJ duurzame energie gebruikt in 2016. Hiervan was $82 \%$ warmte en $18 \%$ elektriciteit (tabel 3.1).

Tabel $3.1 \quad$ Toepassing van duurzame energievormen in de Nederlandse glastuinbouw in 2016 v)

\begin{tabular}{|c|c|c|c|c|c|c|c|}
\hline Duurzame energievorm & Bedrijven a) & Areaal a) & Gemiddeld b) & Warmte & Elektriciteit & Totaal & Aandeel \\
\hline Aardwarmte & 43 & 503 & 11,7 & 2,72 & 0 & 2,72 & 50 \\
\hline Biobrandstof & 36 & 149 & 4,1 & 0,68 & 3 & 0,69 & 13 \\
\hline - warmte & 32 & 130 & 4,1 & 0,48 & - & 0,48 & \\
\hline - elektriciteit & 6 & 149 & 24,8 & - & 2 & 0,01 & \\
\hline - warmte & 61 & 205 & 3,4 & 0,77 & - & 0,77 & \\
\hline Inkoop duurzame elektriciteit d) & - c) & - c) & - c) & - & 260 & 0,94 & 17 \\
\hline Inkoop duurzame gas d) & - c) & $-c)$ & $-c)$ & 0,03 & 0 & 0,03 & 1 \\
\hline - decentraal & 7 & 33 & 4,8 & 0,25 & - & 0,25 & \\
\hline Totaal & 151 & 978 & 6,5 & 4,47 & 265 & 5,42 & 100 \\
\hline
\end{tabular}
a) Peildatum eind 2016.
b) Bedrijven en het bijbehorend areaal met meerdere vormen van duurzame energie eenmaal meegenomen bij de sommatie.
c) Cijfers niet bekend.
d) Duurzame energie van buiten de sector.
v) Cijfers voorlopig. 


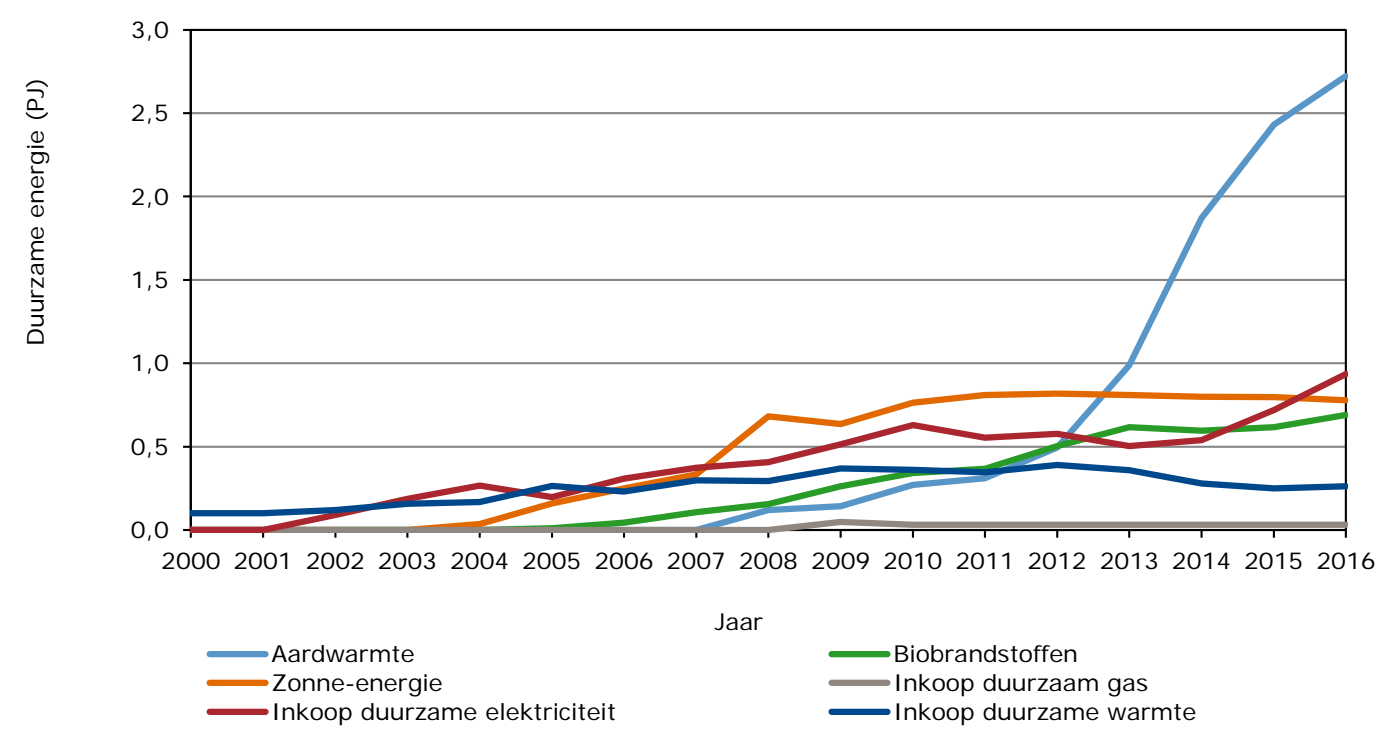

Figuur 3.1 Gebruik duurzame energie in de glastuinbouw per bron per jaar (PJ) v) v) Cijfers 2016 voorlopig.

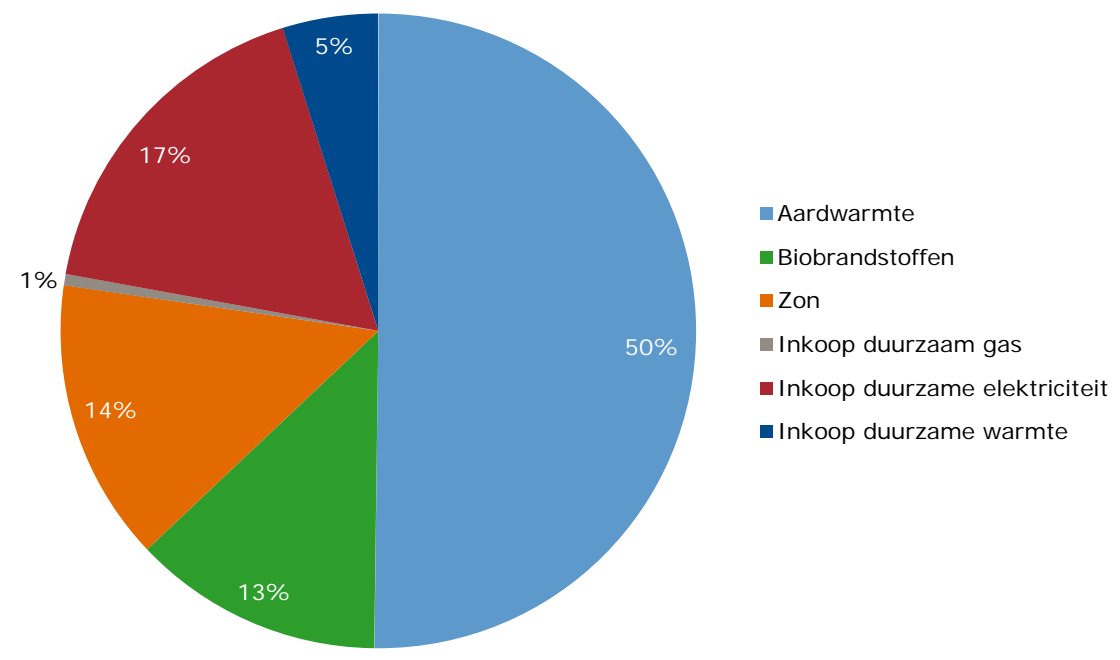

Figuur 3.2 Verdeling gebruik van duurzame energie in de glastuinbouw in 2016 per bron (\%) v) v) Cijfers voorlopig.

\subsubsection{Ontwikkeling per vorm}

\section{Aardwarmte}

In 2016 steeg het aantal glastuinbouwbedrijven dat aardwarmte toepast naar 43. Van de 43 bedrijven met aardwarmte waren 31 exploitant en 12 afnemer. Het areaal met aardwarmte groeide van 459 naar 503 ha. Dit betekent dat in 2016 op ruim 5\% van het totaal areaal glastuinbouw in Nederland aardwarmte werd toegepast. Op 89\% van het areaal met aardwarmte werden groenten geteeld. Het aandeel in het areaal waar aardwarmte werd toegepast dat van andere glastuinbouwbedrijven werd gekocht was $7 \%$ van de 503 ha.

Opvallend is dat recentere projecten minder een maximale invulling van de warmtevraag van de glastuinbouwbedrijven nastreven en meer een maximale benutting van de aardwarmtebron realiseren. Hierdoor groeit het areaal, het aantal bedrijven en het totale gebruik van aardwarmte, maar daalt het gemiddelde gebruik per $\mathrm{m}^{2}$. 
In 2016 waren niet alle projecten het volledige jaar of met het ontwerpvermogen in bedrijf. Dit kwam doordat projecten in de loop van het jaar werden opgestart of door storingen of andere

onderbrekingen. Naar schatting had circa een kwart meer aardwarmte kunnen worden toegepast als in 2016 alle aardwarmteprojecten wel met de beoogde beschikbaarheid hadden gedraaid.

Zonne-energie

De hoeveelheid herwonnen zonnewarmte daalde in 2016 licht. Het werd toegepast door 61 bedrijven met een gezamenlijk glasareaal van 205 ha. Herwinning zonnewarmte ontwikkelt zich al jaren alleen nog bij bedrijven waarbij koude nodig is voor koeling van de teelt. Wel blijft het de duurzame energievorm met de meeste projecten. De zonnewarmte werd vooral toegepast bij plantenbedrijven (115 ha), op afstand gevolgd door bloemen (43 ha) en groente ( $36 \mathrm{ha}$ ). Bij bloemen waren alle bedrijven met herwinning van zonnewarmte uit grondkoeling te vinden en wel bij de gewassen alstroemeria, amaryllis en freesia (samen $40 \mathrm{ha}$ ). Bij planten ging het vooral om phalaenopsis (104 ha). Op meer dan de helft van het totale areaal van deze gewassen wordt koeling gecombineerd met herwinning van zonnewarmte.

In 2016 groeide het aantal bedrijven met winning van elektriciteit via fotovoltaïsche cellen ${ }^{2}$. Deze zonne-elektriciteit werd deels toegepast op de bedrijven en deels verkocht. De toepassing groeit sinds 2014 sterk, mede doordat bedrijven gebruikmaken van stimuleringsregelingen. De bijdrage van zonelektrisch aan de totale hoeveelheid duurzame energie blijft met 0,2\% vooralsnog zeer beperkt.

\section{Biobrandstof}

Het aantal bedrijven waar in 2016 biobrandstof werd toegepast, steeg naar 36. Het areaal nam toe tot 149 ha. Het aantal bedrijven dat biobrandstof gebruikt in een wkk is met 4 bedrijven (samen 19 ha) al jaren stabiel. De inzet van biobrandstof voor de productie van alleen warmte vond plaats bij 32 bedrijven, met een gezamenlijk areaal van 130 ha. Van het areaal met biobrandstof in ketels was 63 ha te vinden bij de groenten, 58 ha bij de planten en 25 ha bij de bloemen. Van de 19 ha met biowkk zat 15 ha bij groenten en 4 ha bij bloemen.

Resthout is al jaren de voornaamste biobrandstof voor de glastuinbouw; van de 36 projecten gebruikten er in 201633 resthout. Drie bedrijven haalden hun biobrandstof uit vergisting (allen biowkk). In 2016 exploiteerden 33 bedrijven een installatie op biobrandstof en namen 3 bedrijven warmte af van glastuinbouwbedrijven die bio-energie produceren.

De combinatie van een stijgende biobrandstofprijs en een relatief lage aardgasprijs leidt vooral bij bestaande projecten steeds vaker tot stevige afweging tussen deze twee brandstofsoorten. In 2016 hebben een aantal, vooral kleinere, installaties hierdoor maar een heel beperkte hoeveelheid duurzame warmte geproduceerd en is het voortbestaan van bio-energieprojecten geen zekerheid.

Inkoop

Door de glastuinbouw wordt duurzame elektriciteit, duurzame warmte en duurzaam gas ingekocht. De duurzaamheid van ingekochte duurzame elektriciteit en gas uit openbare netten wordt met een Garantie van Oorsprong (GVO) gewaarborgd. De glastuinbouwbedrijven kopen duurzame elektriciteit in vanuit een eigen duurzaamheidsmotief of vanuit hun wens deel te nemen aan de regelingen waarbij een mate van duurzaamheid een vereiste is, zoals Groenlabel Kas.

De inkoop van duurzame elektriciteit steeg in 2016 met bijna een kwart naar 260 miljoen kWh. Dit kwam voort uit de noodzaak om het extra elektriciteitsgebruik door de groeiende vraag voor belichting te verduurzamen en aan de vereisten van regelingen te voldoen.

Inkoop van duurzame warmte vindt plaats vanuit centrale en decentrale projecten. Bij centrale inkoop betreft het een deel van de restwarmte dat duurzaam werd opgewekt (bijstook van biobrandstof in elektriciteitscentrales). Bij decentrale projecten wordt op kleinere schaal lokaal duurzame warmte uit biobrandstoffen geleverd aan glastuinbouwbedrijven door exploitanten buiten de sector. De inkoop

\footnotetext{
2 Fotovoltaïsche energie (zonne-elektriciteit) wordt gewonnen met grotere en kleinere installaties. In de Energiemonitor
} worden alleen installaties groter $50 \mathrm{~kW}$ piekvermogen opgenomen. De werkelijke hoeveelheid ligt dus iets hoger. 
van duurzame warmte omvatte in 2016 0,26 PJ. Dit is een stijging van 5\% ten opzichte van 2015 en komt vooral voor rekening van decentrale inkoop.

De aankoopmotieven voor de inkoop van duurzaam gas zijn globaal gelijk aan die voor de inkoop van duurzame elektriciteit. Duurzaam gas betreft biogas dat is geproduceerd en geconverteerd naar een standaardkwaliteit waardoor dit gas via het aardgasnet wordt geleverd aan de eindverbruiker. Het gebruik van duurzaam gas bleef ook in 2016 zeer beperkt van omvang.

Ontwikkelingen

Hoewel de absolute hoeveelheid gebruikte duurzame energie in 2016 steeg, daalde het groeitempo ten opzichte van de voorafgaande twee jaar (figuur 2.4). Een van de oorzaken van deze lagere groei is dat er in 2016 minder nieuwe aardwarmte projecten bijkwamen in vergelijking met 2014 en 2015. Bovendien hadden bestaande aardwarmteprojecten te kampen met productieonderbrekingen en storingen. Naast deze technische problemen ondervonden alle vormen van duurzame warmte in 2016 stevige concurrentie van de relatief lage aardgasprijs en van wkk. Dit laatste hangt samen met de toename van de intensiteit $\left(\mathrm{W} / \mathrm{m}^{2}\right)$ van groeilicht, waardoor de elektriciteitsvraag groter werd en de warmtevraag afnam (paragraaf 2.6).

Nieuwe aardwarmteprojecten vragen grote investeringen en kennen lange, complexe realisatietrajecten. Hiernaast is de beschikbaarheid en openstelling van stimulerings- en garantieregelingen periodiek van aard. Hierdoor kwamen er in 2016 minder nieuwe aardwarmteprojecten bij in vergelijking met 2014 en 2015.

Bij de optie zonnewarmte lijkt er al jaren een verzadigingsniveau bereikt te zijn. Dit hangt samen met het beperkte teeltareaal waarbij koeling nodig is voor de teelt en de complexiteit en het kostenniveau van koude/warmte-opslagsystemen. Bij zon-elektrische energie is er wel flinke groei, de totale bijdrage van deze optie was in 2016 echter nog beperkt van omvang. Nieuwe biobrandstofprojecten zijn schaars door de eerder genoemde relatief lage aardgasprijzen in combinatie met onzekerheid van het prijsniveau van biobrandstof op termijn.

Duurzame energievoorzieningen brengen relatief hoge investeringen met zich mee. Daarnaast hebben glastuinbouwbedrijven beperkte investeringsruimte en ook andere investeringsopties. Met de algemene verbetering van bedrijfsresultaten en vooruitzichten staan onder andere ook vervangingsinvesteringen en nieuwbouw weer volop in de belangstelling en dienen ondernemers keuzes te maken.

Kortom, duurzame energie groeide in 2016 door, maar het groeitempo van duurzame energie nam af, omdat het realiseren van nieuwe duurzame energievoorzieningen complex en risicovol is, het op ontwerpcondities in bedrijf houden van bestaande installaties de nodige inspanning vergt en de concurrentie met het niet-duurzame alternatief aardgas stevig is.

\subsubsection{Productie, inkoop, verkoop en consumptie}

De glastuinbouwsector produceert zelf duurzame energie en daarnaast wordt duurzame energie van buiten de sector ingekocht (figuur 3.3). Een beperkt deel van de zelf geproduceerde energie wordt verkocht buiten de sector (figuur 3.4). Van de toegepaste duurzame energie werd in $201677 \%$ zelf geproduceerd en werd $23 \%$ van buiten de sector ingekocht. Het aandeel van de eigen productie daalde hiermee iets ten opzichte van 2015. Dit kwam vooral door groei van de inkoop van duurzame elektriciteit. Naast inkoop van buiten de sector werd in 2016 5\% van de toegepaste duurzame energie ingekocht bij andere glastuinbouwbedrijven. Duurzame warmte wordt al jaren vooral door de sector zelf geproduceerd (in 2016 93\%), duurzame elektriciteit wordt vooral buiten de sector ingekocht (in 2016 98\%). 


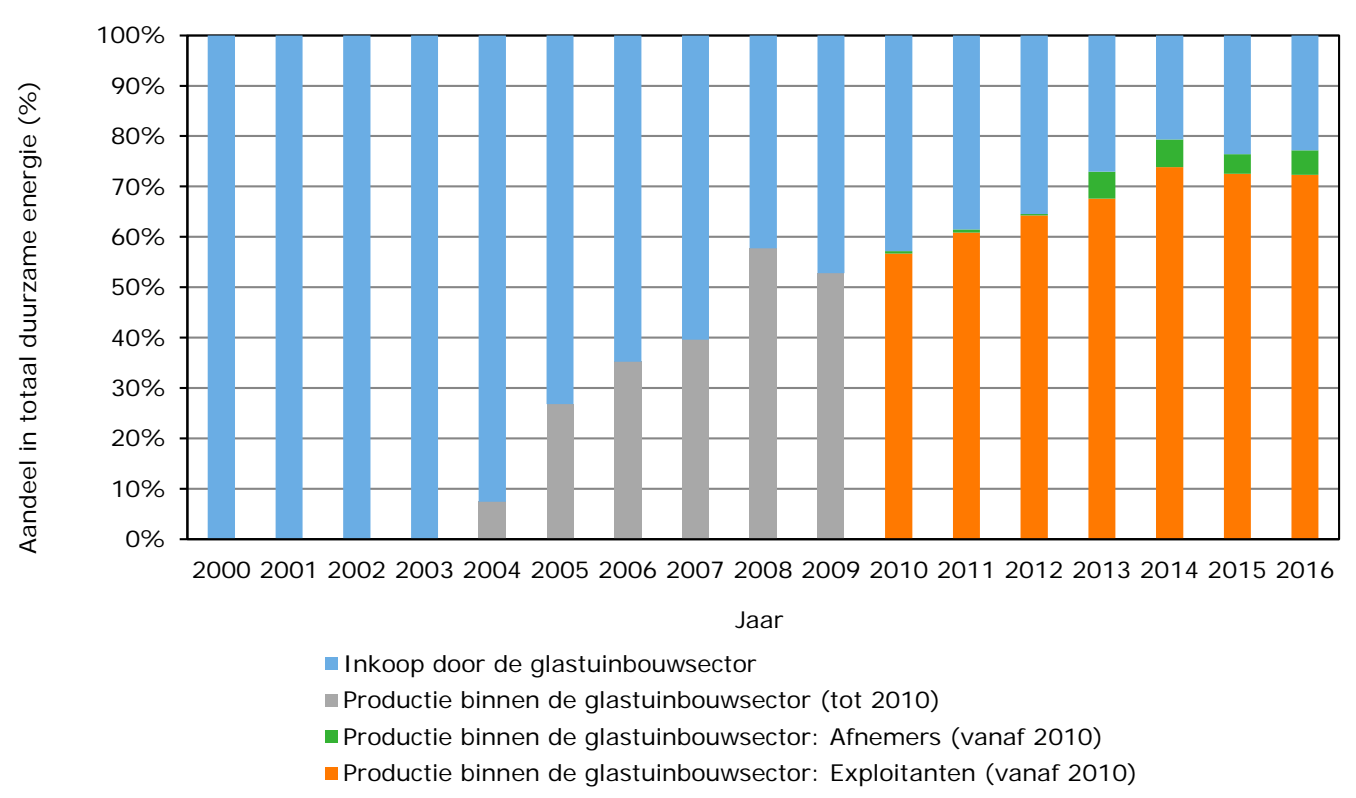

Figuur 3.3 Verdeling van de toepassing van duurzame energie naar herkomst per jaar (\%) a), v) a) Vanaf 2010 wordt de toepassing van door de sector zelf geproduceerde duurzame energie gesplitst naar exploitanten en hun afnemers.

v) Cijfers 2016 voorlopig.

De balans voor duurzame energie (figuur 3.4) laat zien dat het gebruik van duurzame energie voor meer dan driekwart gedekt wordt door eigen productie. Van de zelf geproduceerde, duurzame energie (4,3 PJ) werd voor een beperkt deel (9\%) verkocht, $6 \%$ binnen de sector en $3 \%$ daarbuiten. Binnen de sector verkochte duurzame energie was vooral aardwarmte. De inkoop van collega tuinders steeg in 2016 met 29\% door het herstel van storingen bij bestaande aardwarmteprojecten die warmte verkopen. De verkoop aan afnemers buiten de sector steeg met $6 \%$. De inkoop van duurzame energie van buiten de sector nam in 2016 met $23 \%$ toe.

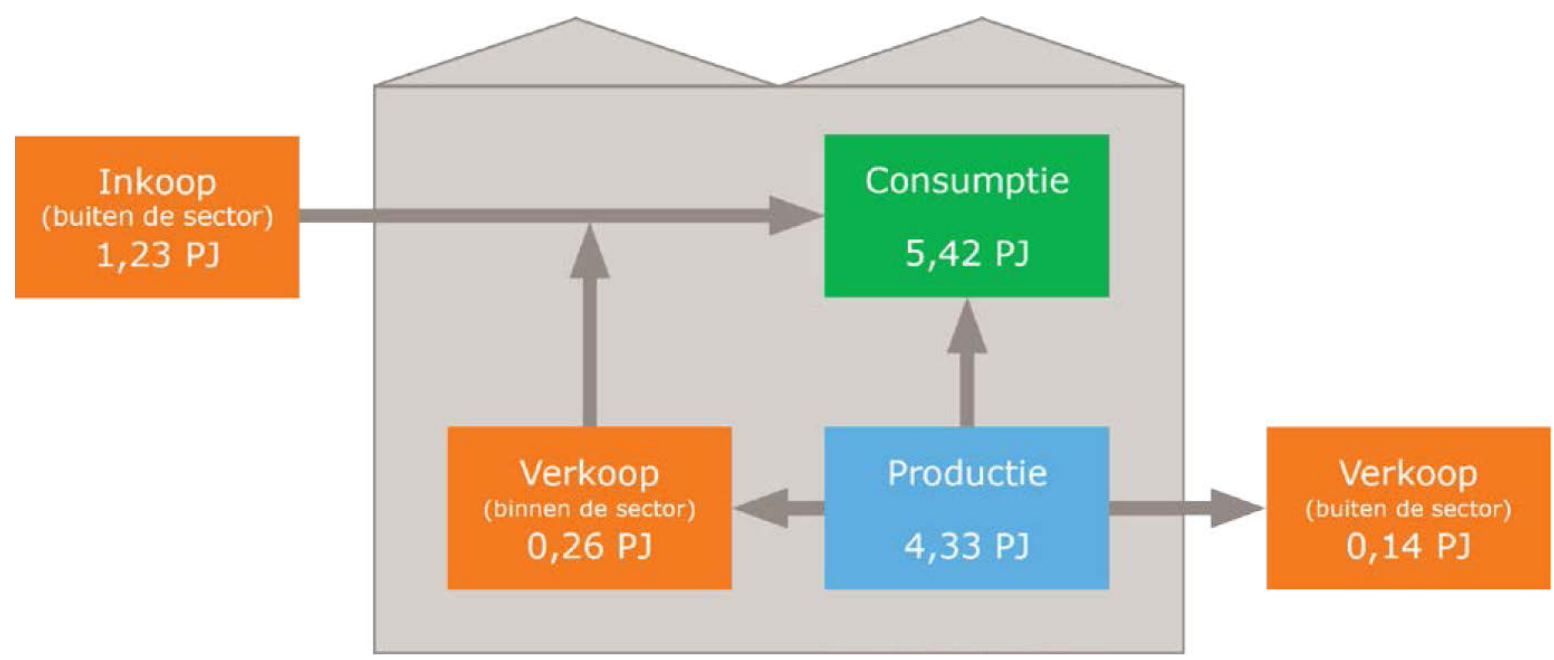

Figuur 3.4 Balans voor duurzame energie van de Nederlandse glastuinbouw in 2016 v) v) Cijfers voorlopig. 


\subsubsection{Bedrijfsstructuur}

\section{Bedrijven en areaal}

Het aantal bedrijven met gebruik van duurzame energie (exclusief inkoop uit openbare netten) groeide in 2016 met $9 \%$ naar 151 (figuur 3.6). Deze groei was het saldo van de start van nieuwe projecten, continuering van bestaande projecten en projecten die werden beëindigd. Het areaal met duurzame energie groeide in 2016 met 16\% naar 978 ha. Dit was bijna 11\% van totale areaal glastuinbouw in Nederland en nog zonder het areaal met inkoop uit openbare netten. In 2016 kwam er meer areaal met duurzame energie bij dan in 2015.

De gemiddelde omvang van de glastuinbouwbedrijven met duurzame energie nam in 2016 toe tot 6,5 ha en is fors groter dan de gemiddelde bedrijfsomvang in de sector (figuur 3.5). Dit komt omdat nieuwe projecten vooral bij grote en zeer grote bedrijven werden gerealiseerd.

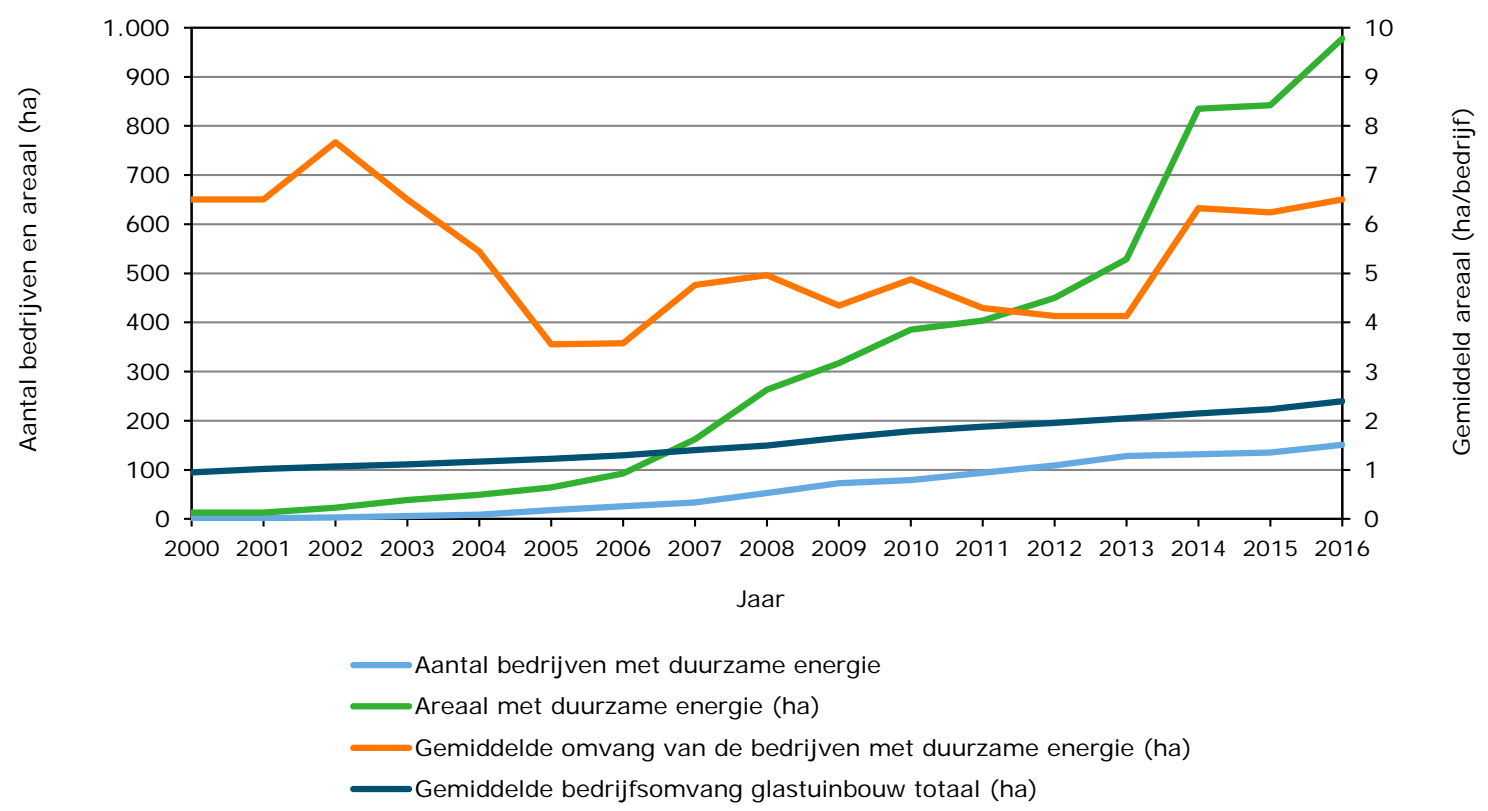

Figuur 3.5 Ontwikkeling van het aantal bedrijven, het areaal en de gemiddelde bedrijfsomvang met duurzame energie en de gemiddelde omvang van alle bedrijven met glastuinbouw a), v)

a) Exclusief inkoop uit openbare netten.

v) Cijfers 2016 voorlopig.

\section{Subsectoren}

In elk van de vier subsectoren in de glastuinbouw wordt duurzame energie toegepast (figuur 3.6). De meeste duurzame energie werd toegepast op het groenteareaal, en het minst bij uitgangsmateriaal. Deze twee subsectoren zijn qua areaal in Nederland ook de grootste en de kleinste. Bloemen en planten zitten hier tussen in. Ook in 2016 werd op het areaal bloemen het minste duurzame energie toegepast. Bij bloementeelt wordt gemiddeld minder warmte en meer groeilicht toegepast, waardoor het complexer is om duurzame energie in te passen. Bij groentebedrijven wordt meer $\mathrm{CO}_{2}$-gedoseerd met wkk en dit concurreert met duurzame warmte. Plantenbedrijven hanteren een relatief hoge kastemperatuur, belichten minder intensief en doseren minder $\mathrm{CO}_{2}$. Hierdoor ondervindt duurzame energie op plantenbedrijven minder concurrentie van ketels en wkk. De verdeling van areaal met duurzame energie over de subsectoren vertoont de laatste jaren weinig verandering. 


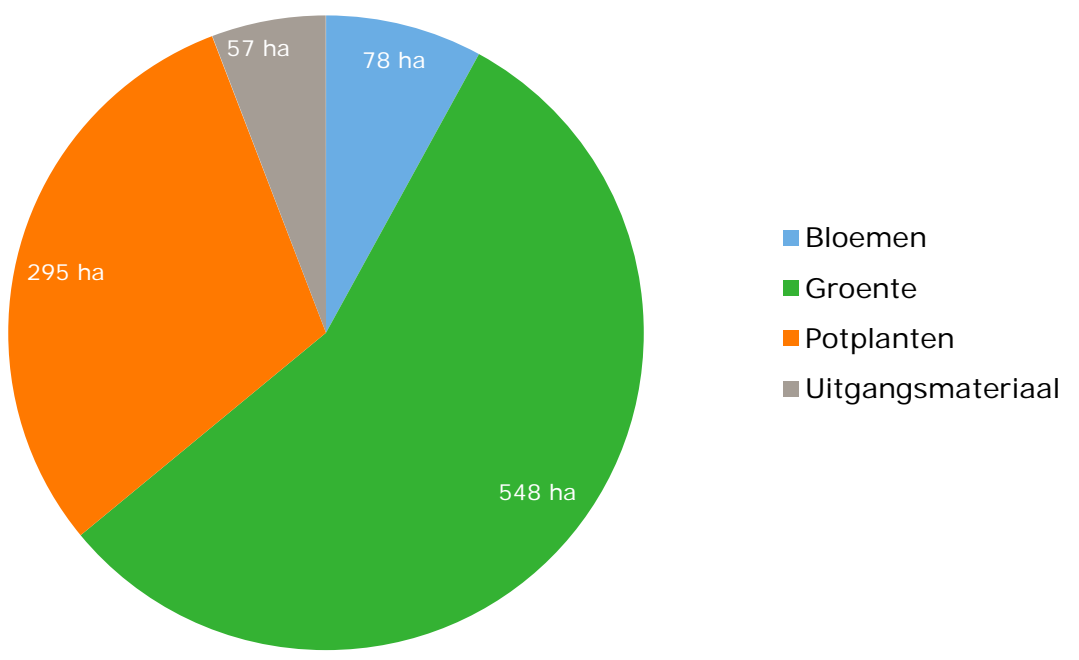

Figuur 3.6 Verdeling van het areaal met duurzame energietoepassing per subsector in 2016 (ha) a) v) a) Exclusief inkoop uit openbare netten.

v) Cijfer voorlopig.

Bedrijfsomvang en bedrijven per duurzame bron Als gekeken wordt naar de toepassing van duurzame energie die wordt geproduceerd door glastuinbouwbedrijven dan valt op dat dit vooral plaatsvond op grotere bedrijven (figuur 3.7). Circa $80 \%$ van de duurzame energie wordt toegepast op grote (4-8 ha) en zeer grote ( $>8$ ha) bedrijven. Het gezamenlijke areaal met toepassing van duurzame energie bij kleine (1-2 ha) en zeer kleine ( $<1$ ha) bedrijven daalde in 2016 naar 5\% van het totaal areaal met duurzame energie. Het voorgaande hangt samen met de relatief hoge investeringen die gepaard gaan met duurzame energie.

Van de 151 bedrijven die in 2016 duurzame energie toepasten, behoorden er 28 tot de groep van zeer grote bedrijven. Deze 28 bedrijven namen meer dan de helft van de toegepaste duurzame energie voor hun rekening (vooral aardwarmte). De toepassing door kleine en zeer kleine bedrijven betrof hoofdzakelijk biobrandstof en herwinning van zonnewarmte. Herwinning van zonnewarmte en inkoop duurzame warmte kwam met name voor bij gemiddelde en grote bedrijven.

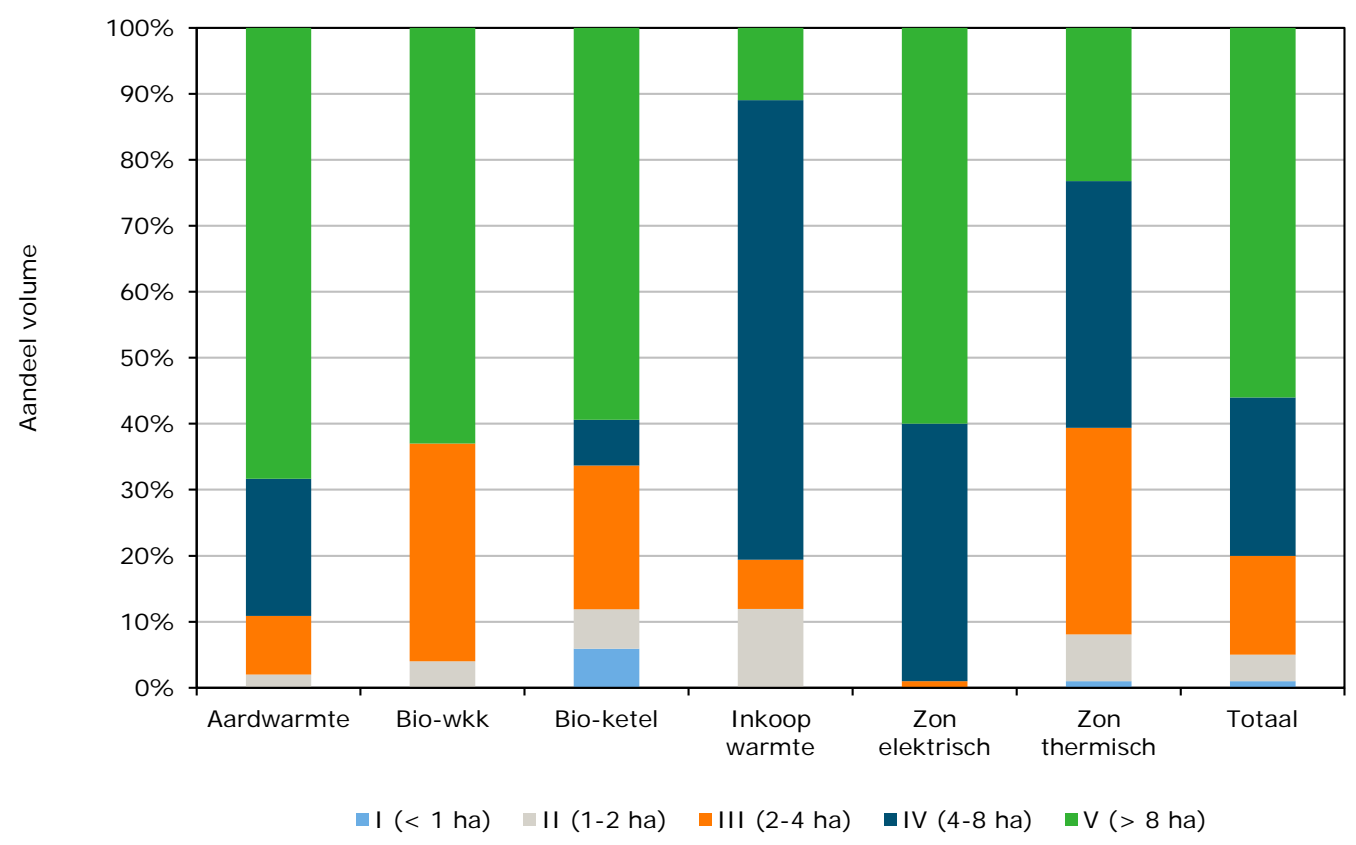

Figuur 3.7 Verdeling volume duurzame energie over bedrijfsgrootteklassen per vorm in 2016 (\%) v) v) Cijfer voorlopig. 


\subsection{Inkoop $\mathrm{CO}_{2}$}

In 2016 werd zo'n 0,55 Mton $\mathrm{CO}_{2}$ extern ingekocht en dat is iets meer dan in de voorafgaande twee jaar. In de periode 2009-2013 is de jaarlijkse inkoop afgenomen maar vanaf 2013 is er een toename. Verwacht wordt dat de eerdere afname samenhing met de economische crisis. De toename vanaf 2013 duidt er op dat bedrijven $\mathrm{CO}_{2}$ blijven inkopen voor productie-optimalisatie en energieverduurzaming. De gemiddelde toepassing van externe $\mathrm{CO}_{2}$ nam op het totale areaal glastuinbouw, in 10 jaar met ruim $2 \mathrm{~kg}$ toe tot bijna $6 \mathrm{~kg}$ per $\mathrm{m}^{2}$ in 2016. Op het areaal waar deze $\mathrm{CO}_{2}$ werd ingekocht bedroeg dit in 2016 circa $30 \mathrm{~kg}$ per $\mathrm{m}^{2}$.

De inkoop van $\mathrm{CO}_{2}$ van buiten de sector is op zich geen duurzame energie. Wel is deze inkoop van $\mathrm{CO}_{2}$ nodig om de inzet van duurzame energie te kunnen toepassen en verder te laten groeien. Bij duurzame energieproductie komt immers geen $\mathrm{CO}_{2}$ vrij. Ook kan de inzet van externe $\mathrm{CO}_{2}$ de zomerstook verminderen. Met zomerstook wordt de $\mathrm{CO}_{2}$ productie uit aardgas zonder warmtebenutting bedoeld en het vermijden hiervan is energiebesparing (paragraaf 2.5).

Externe $\mathrm{CO}_{2}$ komt beschikbaar als bijproduct van industriële processen. Onderscheid wordt gemaakt tussen $\mathrm{CO}_{2}$ uit rookgassen en zuivere $\mathrm{CO}_{2}$ en tussen centrale en decentrale levering (figuur 3.10). Het gebruik van externe $\mathrm{CO}_{2}$ in de glastuinbouw betreft vooral centrale levering van zuivere $\mathrm{CO}_{2}$. De hoeveelheid rookgas $\mathrm{CO}_{2}$ is zeer beperkt. Decentraal zuiver $\mathrm{CO}_{2}$ aangeleverd per as neemt een tussenpositie in en groeide in 2016. Sinds 2012 zijn er geen projecten meer met centrale levering van rookgas $\mathrm{CO}_{2}$. Voor de verdere ontwikkeling van het gebruik van duurzame energie is groei van externe $\mathrm{CO}_{2}$-voorziening van groot belang.

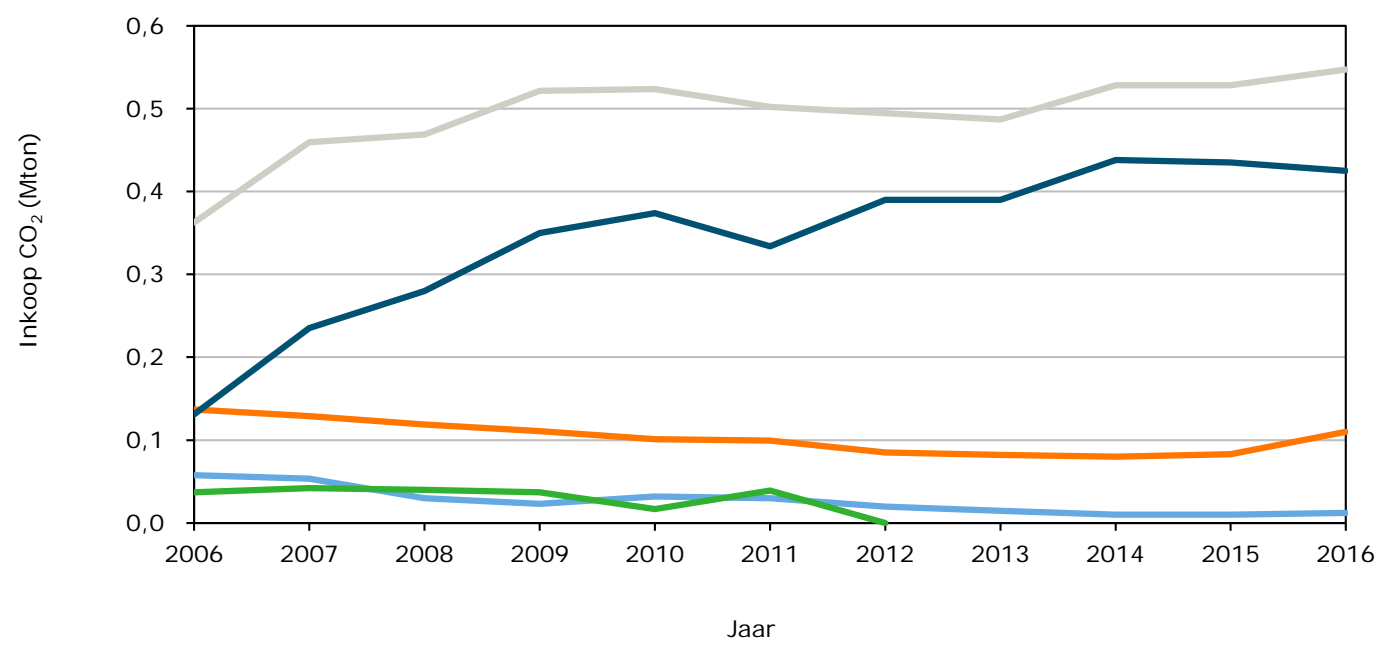

Decentraal rookgas Centraal rookgas $\longrightarrow$ Decentraal zuiver Centraal zuiver $=$ Totaal

Figuur 3.8 Ontwikkeling van de inkoop van externe $\mathrm{CO}_{2}$ door de Nederlandse glastuinbouw v) v) Cijfers 2016 voorlopig.

\subsection{Reductie $\mathrm{CO}_{2}$-emissie}

Productie, inkoop en verkoop van duurzame energie door de glastuinbouw reduceert zowel binnen als buiten de glastuinbouw de $\mathrm{CO}_{2}$-emissie. Verandering van de $\mathrm{CO}_{2}$-emissie kan zowel op sectorniveau (op basis van de IPCC-methode) als op nationaal niveau (op basis van het primair brandstofverbruik) worden uitgedrukt (tabel 3.2 en bijlage 4). De daling van de $\mathrm{CO}_{2}$-emissie door duurzame energie op sectorniveau bedroeg in 2016 0,25 Mton en de nationale reductie 0,34 Mton. Het effect op 
sectorniveau is lager dan de reductie op nationaal niveau. Dit komt doordat bij de IPCC-methode de energieverkoop, de extra elektriciteitsconsumptie door duurzame energiebronnen en de inkoop van duurzame elektriciteit niet meetellen (hoofdstuk 2).

Tabel 3.2 Reductie $\mathrm{CO}_{2}$-emissie per duurzame energiebron in $2016 \mathrm{v}$ )

\begin{tabular}{|c|c|c|c|c|}
\hline \multirow[t]{2}{*}{ Duurzame energiebron } & \multicolumn{2}{|c|}{ Sectoraal/ I PPC } & \multicolumn{2}{|c|}{ Nationaal/ primair brandstof } \\
\hline & Mton & $\%$ & Mton & $\%$ \\
\hline Aardwarmte & 0,15 & 61 & 0,13 & 40 \\
\hline Zonne-energie (elektriciteit) & 0,00 & 0 & $<0,01$ & $<1$ \\
\hline Zonne-energie (warmte) & 0,04 & 17 & 0,02 & 5 \\
\hline Biobrandstof (warmtekracht) & 0,01 & 5 & 0,03 & 7 \\
\hline Biobrandstof (warmte) & 0,03 & 11 & 0,03 & 7 \\
\hline Inkoop duurzaam gas & $<0,01$ & $<1$ & $<0,01$ & $<1$ \\
\hline Inkoop duurzame elektriciteit & 0,00 & 0 & 0,12 & 36 \\
\hline Inkoop duurzame warmte (centraal) & $<0,01$ & $<1$ & $<0,01$ & $<1$ \\
\hline Inkoop duurzame warmte (decentraal) & 0,01 & 6 & 0,01 & 4 \\
\hline Totaal & 0,24 & 100 & 0,34 & 100 \\
\hline
\end{tabular}

v) Cijfers 2016 voorlopig.

In de periode 2005-2016 steeg de bijdrage van duurzame energie aan de daling van het primair brandstofverbruik (en dus van de nationale $\mathrm{CO}_{2}$-emissie) van 25 naar 190 miljoen $\mathrm{m}^{3}$ a.e.

(figuur 3.11). De besparing door de eigen productie nam ieder jaar toe. De grootste toename zat in de periode na 2013. Vanaf 2009 was de besparing door inkoop min of meer stabiel maar vanaf 2014 groeit dit weer door de toename van de inkoop van duurzame elektriciteit. Sinds 2013 is de besparing in de sector door eigen productie groter dan de besparing door inkoop. Duurzame energie had in 2016 een positief effect op de energie-efficiëntie van 2 procentpunten.

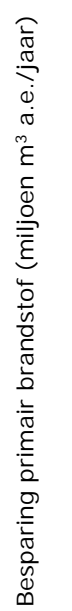
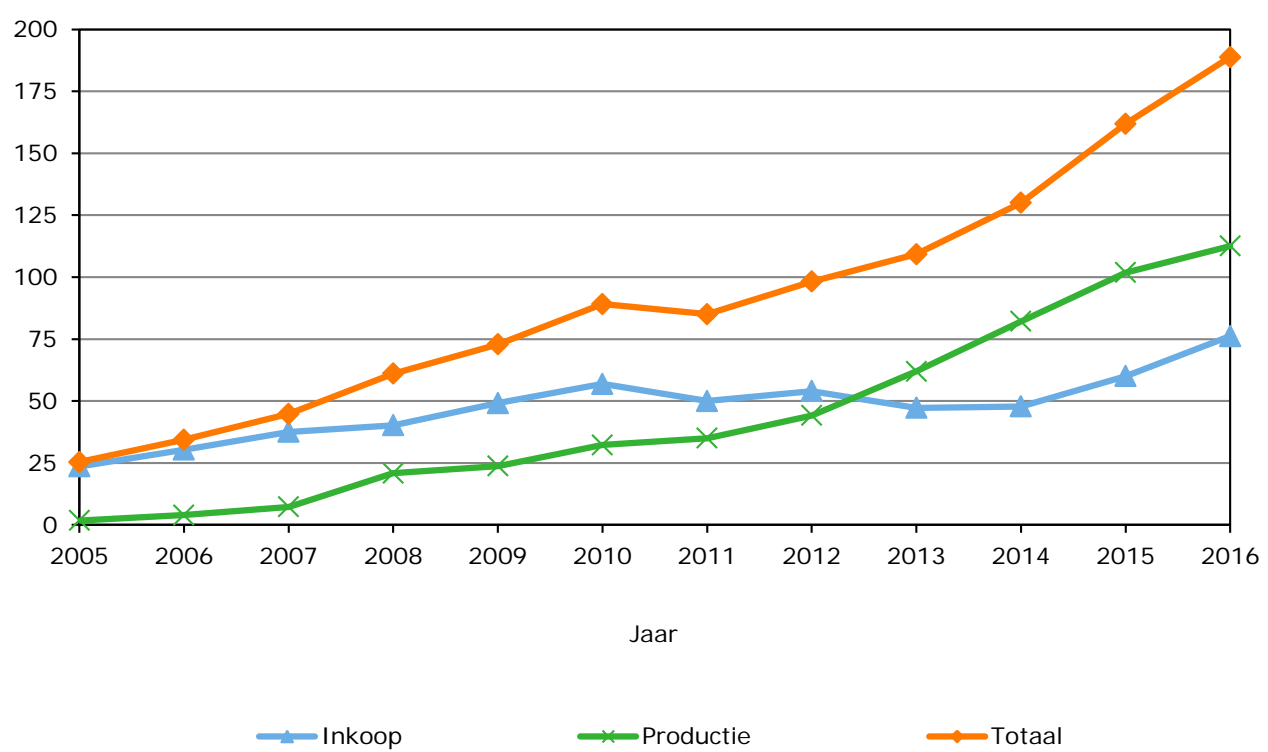

Figuur 3.9 Besparing primair brandstof (miljoen $\mathrm{m}^{3}$ a.e.) door duurzame energie v) v) Cijfers 2016 voorlopig. 


\section{$4 \quad$ Warmtekrachtkoppeling, inkoop warmte en elektriciteitsbalans}

\subsection{Inleiding}

De glastuinbouw maakt op grote schaal gebruik van warmtekrachtkoppeling (wkk). Bij deze gecombineerde productie van warmte en elektriciteit wordt, anders dan bij de meeste elektriciteitscentrales, de warmte die vrijkomt bij de productie van elektriciteit nuttig gebruikt (Smit en Van der Velden, 2008). Bij elektriciteitsproductie door elektriciteitscentrales (zonder warmtelevering) wordt minder dan de helft van de brandstof omgezet in elektriciteit. Wkk draagt daardoor bij aan verlaging van het nationale brandstofverbruik en verlaging van de nationale $\mathrm{CO}_{2}-$ emissie.

Het gebruik van wkk in de glastuinbouw betreft vooral wk-installaties (aardgasmotoren) die de glastuinbouwbedrijven zelf exploiteren (paragraaf 4.2). In deze rapportage wordt met wkk bedoeld de wk-installaties van de glastuinders. Daarnaast wordt gebruik gemaakt van restwarmte van elektriciteitscentrales en wordt op zeer beperkte schaal gebruik gemaakt van wk-installaties van energiebedrijven. Ook wordt warmte afgenomen van de industrie. Bij deze laatste drie vormen koopt de glastuinbouw warmte en eventueel $\mathrm{CO}_{2}$ in (paragraaf 4.3). Door wkk en inkoop warmte wordt $\mathrm{CO}_{2-}$ emissie gereduceerd (paragraaf 4.3). De exploitatie van wkk door glastuinbouwbedrijven is van invloed op de elektriciteitsbalans (paragraaf 4.5) en op de energiekosten van de glastuinbouw. De energiekosten zijn behandeld in paragraaf 2.6 .

Op beperkte schaal gebruikt de glastuinbouw ook wkk die draaien op biobrandstof en wordt duurzame warmte ingekocht van wkk van derden die draaien op biobrandstof. Dit is duurzame energie en is behandeld in hoofdstuk 3.

\subsection{Warmtekrachtkoppeling glastuinbouwbedrijven}

Vermogen en areaal

Het totale elektrische vermogen van de wkk van tuinders is sinds 2012 gedaald. In 2011 was er nog zo'n $2.900 \mathrm{MW}_{\mathrm{e}}$ in gebruik. In 2016 is dat totaal vermogen gedaald naar tussen de 2.700 en 2.800 $\mathrm{MW}_{\mathrm{e}}$ (figuur 4.1). De daling is vooral veroorzaakt door krimp van het areaal glastuinbouw, verslechterde spark spread en door de groei van het gebruik van duurzame energie. Eind 2016 had circa twee derde van het totaal glastuinbouwareaal een wkk in gebruik. Voor de toekomst wordt een verdere vermindering van het totale wkk-vermogen verwacht.

Naast het gebruik van elektriciteit en warmte worden de gereinigde rookgassen van de wkk op grote schaal toegepast voor $\mathrm{CO}_{2}$-dosering bij de gewassen. Door het gebruik van wkk komt er meer $\mathrm{CO}_{2}$ beschikbaar, doordat er naast warmte ook aardgas wordt verbrand voor elektriciteitsproductie. Deze extra rookgas $\mathrm{CO}_{2}$ is gunstig voor de ontwikkeling van de fysieke productie (paragraaf 2.2).

Gebruik elektriciteit

De door de glastuinbouwbedrijven met wkk geproduceerde elektriciteit wordt voor ruim de helft verkocht op de elektriciteitsmarkt en het resterende deel wordt gebruikt door de glastuinbouw. Het eigen gebruik hangt hoofdzakelijk samen met het gebruik van groeilicht.

Verkoop van elektriciteit vindt plaats op vrijwel alle bedrijven met een wkk. Door bedrijven met groeilicht wordt minder verkocht en meer zelf gebruikt dan door bedrijven zonder groeilicht. 
De verkoop van elektriciteit vindt vooral overdag tijdens werkdagen plaats. In deze uren is de elektriciteitsprijs hoger. Bovendien past dit bij de behoefte aan $\mathrm{CO}_{2}$ die de meeste gewassen juist overdag hebben en waarin de gereinigde rookgassen van de wkk dan kunnen voorzien.

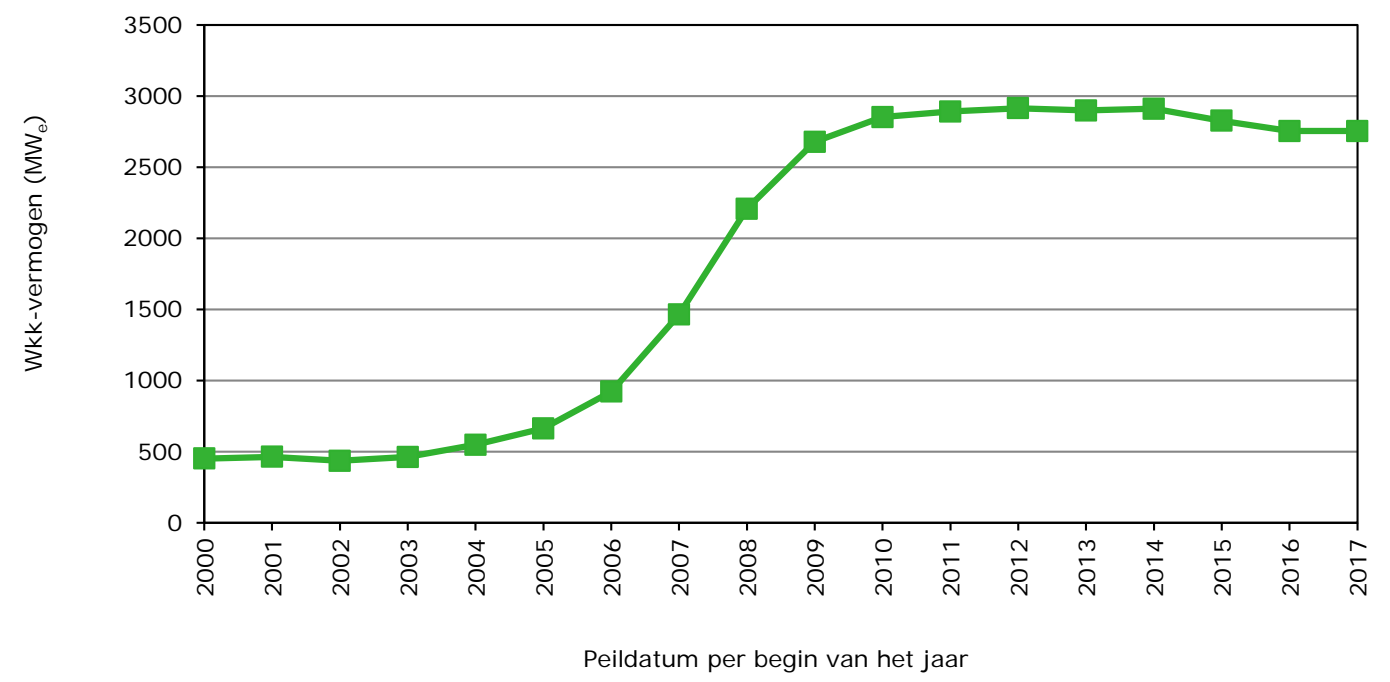

Figuur 4.1 Wkk-vermogen glastuinbouw a)

a) peildatum begin van het jaar; cijfers 2016 en 2017 voorlopig.

Bron: Energy Matters (plaatsing) en Wageningen Economic Research (totaal en sanering).

Gebruiksduur installaties

De gebruiksduur (equivalente vollasturen per jaar) van de wkk is in de periode 2011-2016 gedaald (figuur 4.2). De sterkste daling vond plaats in 2014. In 2016 lag de gebruiksduur zo'n 20\% lager dan in 2011. De ontwikkeling van de gebruiksduur hing samen met de verslechterde spark spread (paragraaf 2.6), waardoor er minder elektriciteit werd verkocht en door de extra elektriciteitsconsumptie door de glastuinbouw voor vooral belichting. Door deze elektriciteitsvraag, zal het gebruik van wkk op korte en middellange termijn belangrijk blijven.

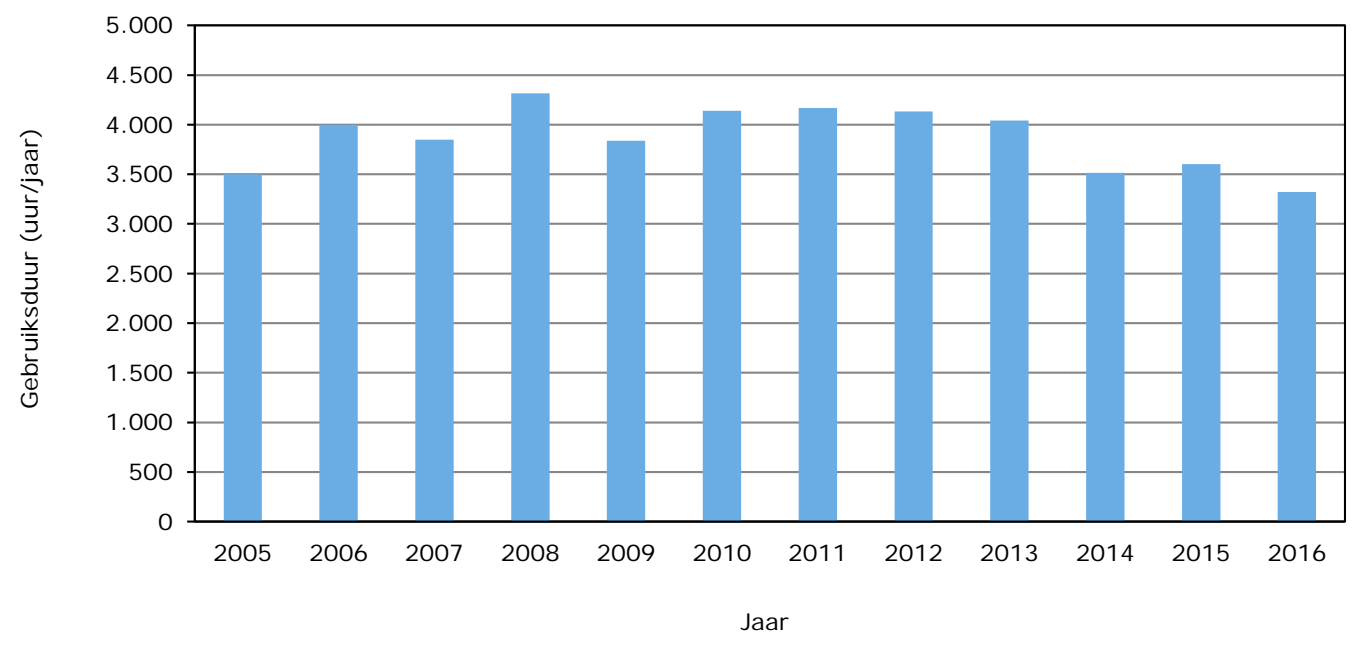

Figuur 4.2 Globale gemiddelde gebruiksduur wkk tuinders a)

a) Cijfers 2016 voorlopig. 
Het wkk vermogen en de gebruiksduur bepalen de elektriciteitsproductie. Dit wordt behandeld bij de elektriciteitsbalans (paragraaf 4.5).

\subsection{Inkoop warmte}

De glastuinbouw koopt warmte in van elektriciteitscentrales, industrie en vanuit wk-installaties van energiebedrijven. In 2016 werd totaal 3,7 PJ warmte ingekocht (figuur 4.3). Dit is bijna 4\% van het totale energiegebruik van de glastuinbouw. Hiervan was $97 \%$ afkomstig van elektriciteitscentrales en industrie en de resterende $3 \%$ van wk-installaties van energiebedrijven.

De totale inkoop van warmte neemt af sinds het einde van de vorige eeuw, maar de inkoop van restwarmte van centrales en industrie liet na 2014 een lichte toename zien. Dit kwam door uitbreiding van het areaal kassen bij bestaande warmteprojecten en door de lagere buitentemperatuur. De inkoop van warmte van wk-installaties van energiebedrijven nam verder af, omdat installaties uit gebruik werden genomen of aan tuinders zijn overgedragen. Begin 2016 was het vermogen met minder dan $20 \mathrm{MW}_{\mathrm{e}}$ nog maar zeer beperkt van omvang, terwijl er rond de eeuwwisseling nog ruim $500 \mathrm{MW}_{\mathrm{e}}$ door energiebedrijven in gebruik was.

Een deel van de ingekochte restwarmte werd met biobrandstof door de centrales geproduceerd. Dit telt mee als inkoop van duurzame energie (hoofdstuk 3).

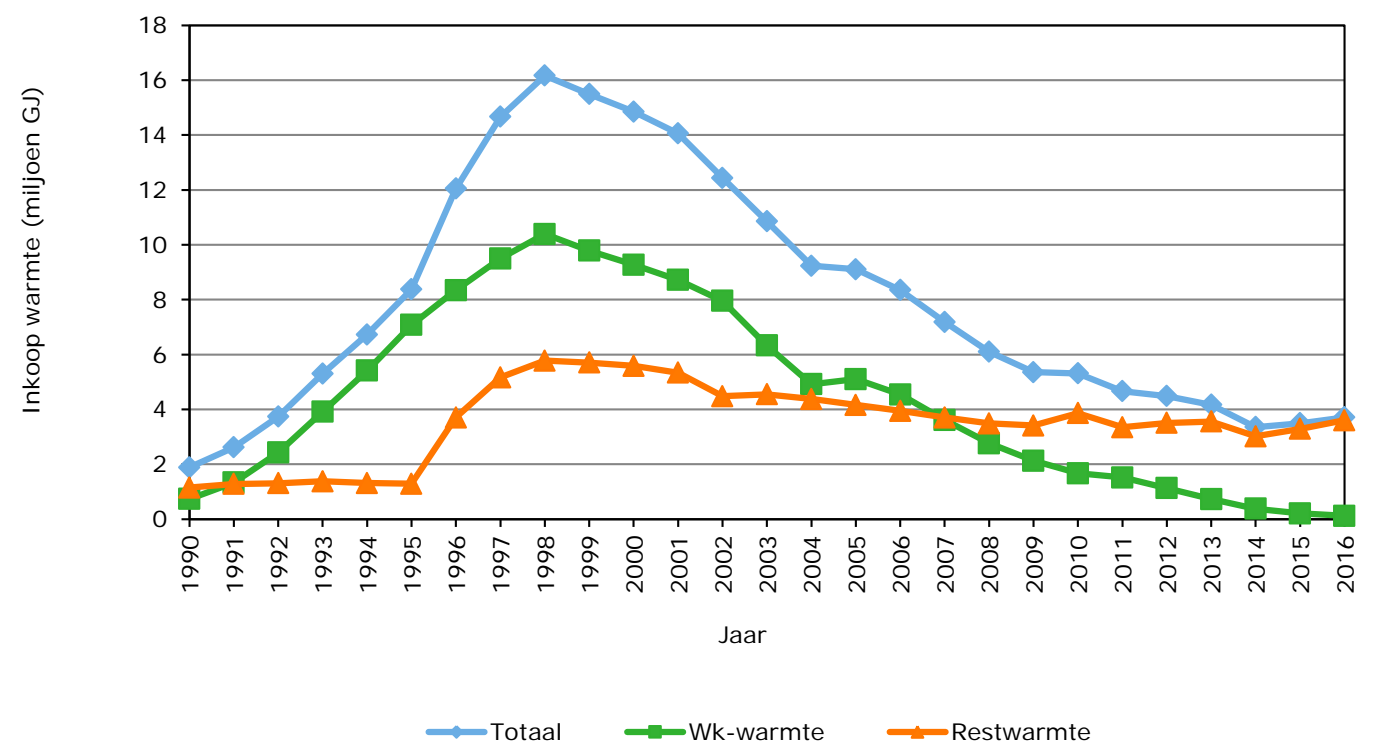

Figuur 4.3 Inkoop van warmte door de glastuinbouw a)

a) Cijfers 2016 voorlopig.

\subsection{Reductie $\mathrm{CO}_{2}$-emissie}

\section{Achtergronden}

De reductie van de $\mathrm{CO}_{2}$-emissie door wkk kan op twee manieren worden bepaald. De ene insteek is de $\mathrm{CO}_{2}$-emissie c.q. het fossiele brandstofverbruik op sectorniveau. De andere insteek is de $\mathrm{CO}_{2}$-emissie nationaal c.q. het primair brandstofgebruik. De effecten van de inzet van wkk door de tuinbouw zijn ook van invloed op de $\mathrm{CO}_{2}$-emissie buiten de glastuinbouw. Er wordt aardgas ingekocht en elektriciteit verkocht (wkk tuinders). Hierdoor neemt de $\mathrm{CO}_{2}$-emissie in de glastuinbouwsector toe (IPCCmethode), terwijl dit nationaal (bij elektriciteitscentrales) afneemt. Dit laatste effect is groter dan de 
toename van de emissie in de glastuinbouw, waardoor per saldo op nationaal niveau $\mathrm{CO}_{2}$-emissie wordt vermeden. Bij inkoop van warmte wordt er minder aardgas verbruikt in de glastuinbouw maar kan er buiten de glastuinbouw extra aardgas nodig zijn. Door het voorgaande is het beter het effect van wkk en van inkoop warmte nationaal te bezien en te kwantificeren op basis van het primair brandstofverbruik.

\section{Warmtekrachtkoppeling tuinders}

De wkk van de tuinders besparen een substantiële hoeveelheid primair brandstof. In de jaren 20082013 bedroeg de besparing gemiddeld bijna 1,3 miljard $\mathrm{m}^{3}$ a.e. per jaar (figuur 4.4). Dit komt overeen met bijna een derde van het totale aardgasverbruik van de glastuinbouw en resulteerde in genoemde jaren in een positief effect op de energie-efficiëntie van zo'n 20 procentpunten. Door afname van het totaal wkk-vermogen van de tuinders en de verminderde gebruiksduur is de besparing aan primair brandstof na 2013 teruggelopen tot zo'n 1,0 miljard $\mathrm{m}^{3}$ a.e. in 2016. Deze besparing komt overeen met een nationale reductie van de $\mathrm{CO}_{2}$-emissie van 1,8 Mton (tabel 4.1). In de jaren 20082013 lag de nationale reductie op het niveau van 2,3 Mton.

Inkoop warmte

De reductie van het primair brandstofverbruik door de inkoop van warmte daalde in de periode 20052014 van bijna 200 naar 74 miljoen $\mathrm{m}^{3}$ a.e. (figuur 4.4), om na 2014 weer iets te stijgen naar 84 miljoen $\mathrm{m}^{3}$ a.e. in 2016. De inkoop van warmte droeg in 20161 procentpunt bij aan de verbetering van de energie-efficiëntie. De $\mathrm{CO}_{2}$-emissie in de glastuinbouw (fossiel brandstofverbruik) lag door inkoop van warmte in 2016 0,20 Mton lager en nationaal (primair brandstof) met 0,15 Mton lager.

Tabel 4.1 Reductie $\mathrm{CO}_{2}$-emissie door wkk en inkoop warmte in 2016 a)

\begin{tabular}{lrr} 
Wkk bron & CO $_{2}$-reductie nationaal \\
Wkk-tuinders & Miton \\
\hline Inkoop warmte & 1,79 & 92 \\
\hline Totaal & 0,15 & $\mathbf{1 , 9 4}$ \\
\hline
\end{tabular}

a) Cijfers voorlopig

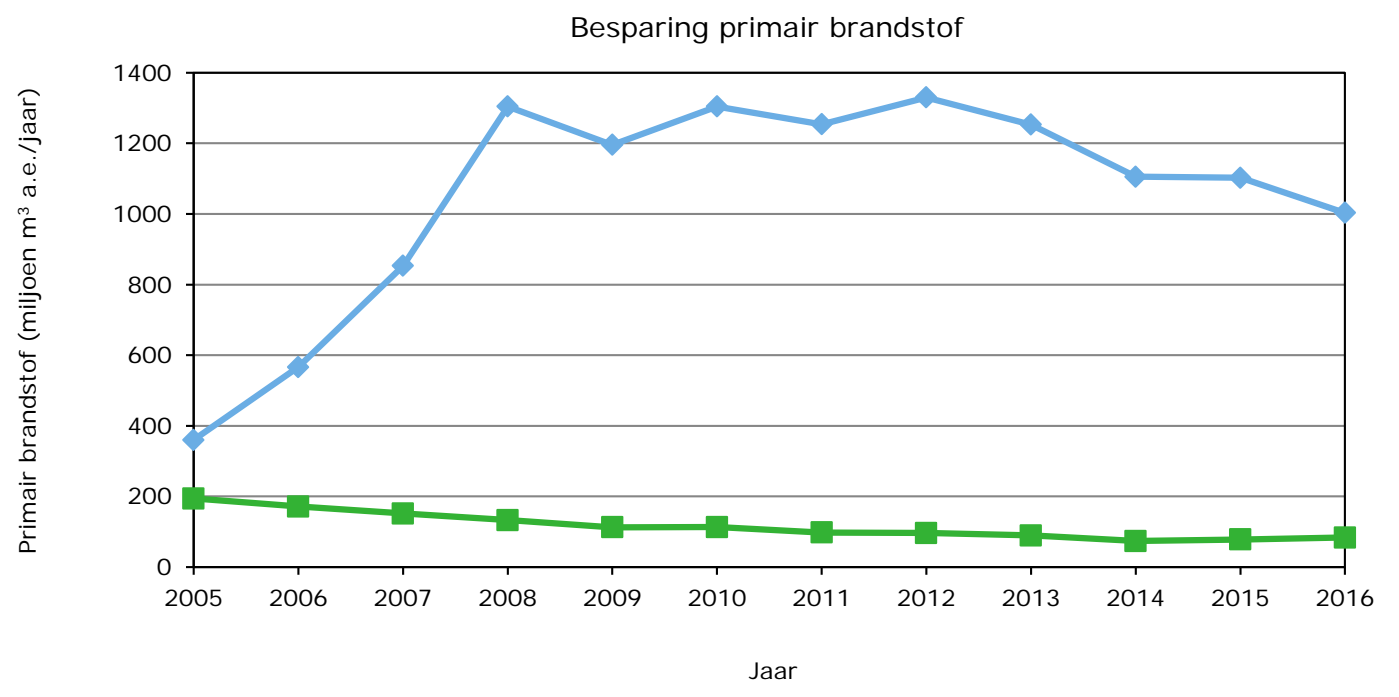

$\leadsto$ Wkk-aardgas $\quad=$ Inkoop warmte

Figuur 4.4 Reductie primair brandstofverbruik door het gebruik van wkk door tuinders en door inkoop van warmte a)

a) Cijfers 2016 voorlopig. 


\subsection{Elektriciteitsbalans}

De elektriciteitsbalans bestaat uit de elementen productie, verkoop, inkoop en consumptie. In deze paragraaf worden deze elementen achtereenvolgens behandeld. Het totaal overzicht van de ontwikkelingen van deze elementen is opgenomen in figuur 4.5. De elektriciteitsbalans van 2016 is weergegeven in figuur 4.6.

De consumptie is berekend door de productie te verminderen met de verkoop en de inkoop er bij op te tellen. Hierdoor werken eventuele statistische fouten in de laatste drie elementen door in de consumptie. De consumptie moet daardoor als een globale indicatie worden gezien. Ook dienen daardoor de ontwikkelingen over een periode van meerdere jaren te worden bezien.

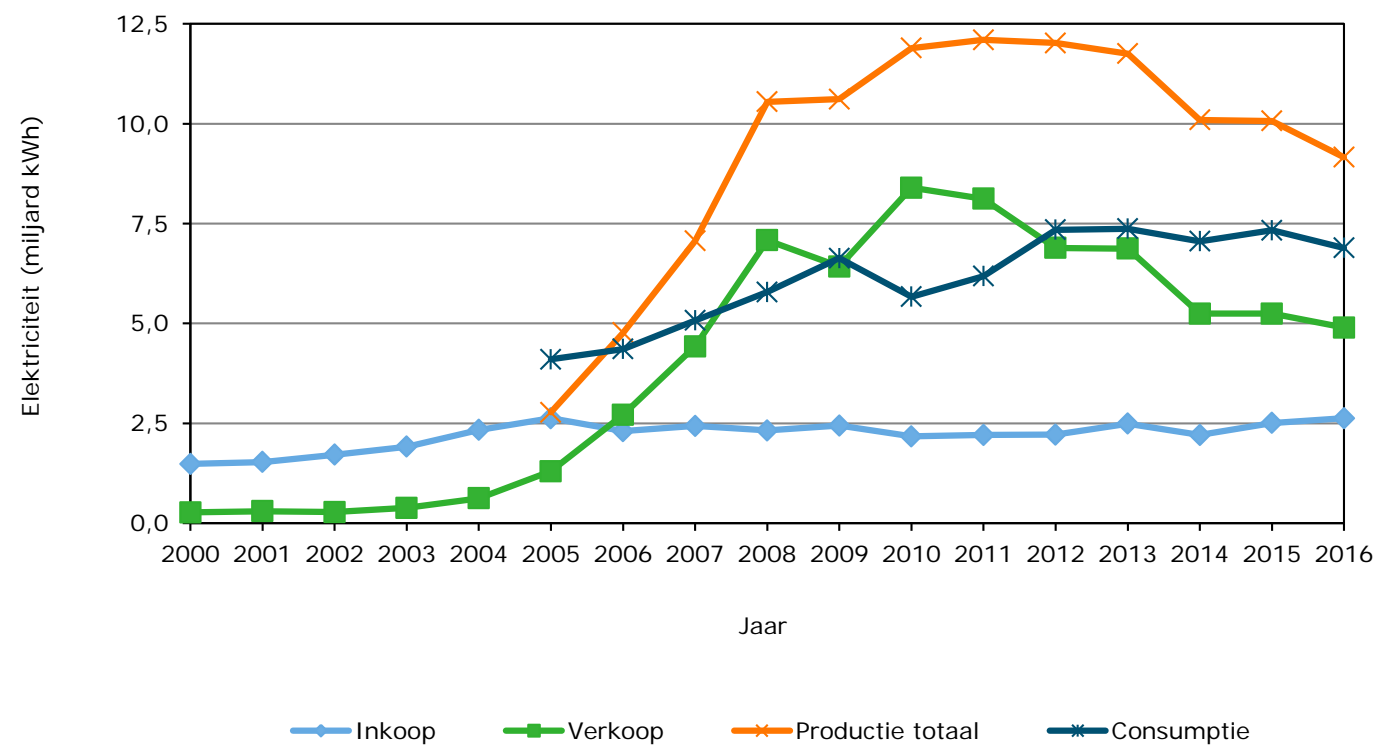

Figuur 4.5 Inkoop, verkoop, productie en consumptie van elektriciteit door de glastuinbouw a) a) De productie en de consumptie tot 2005 zijn niet bekend; cijfers 2016 voorlopig.

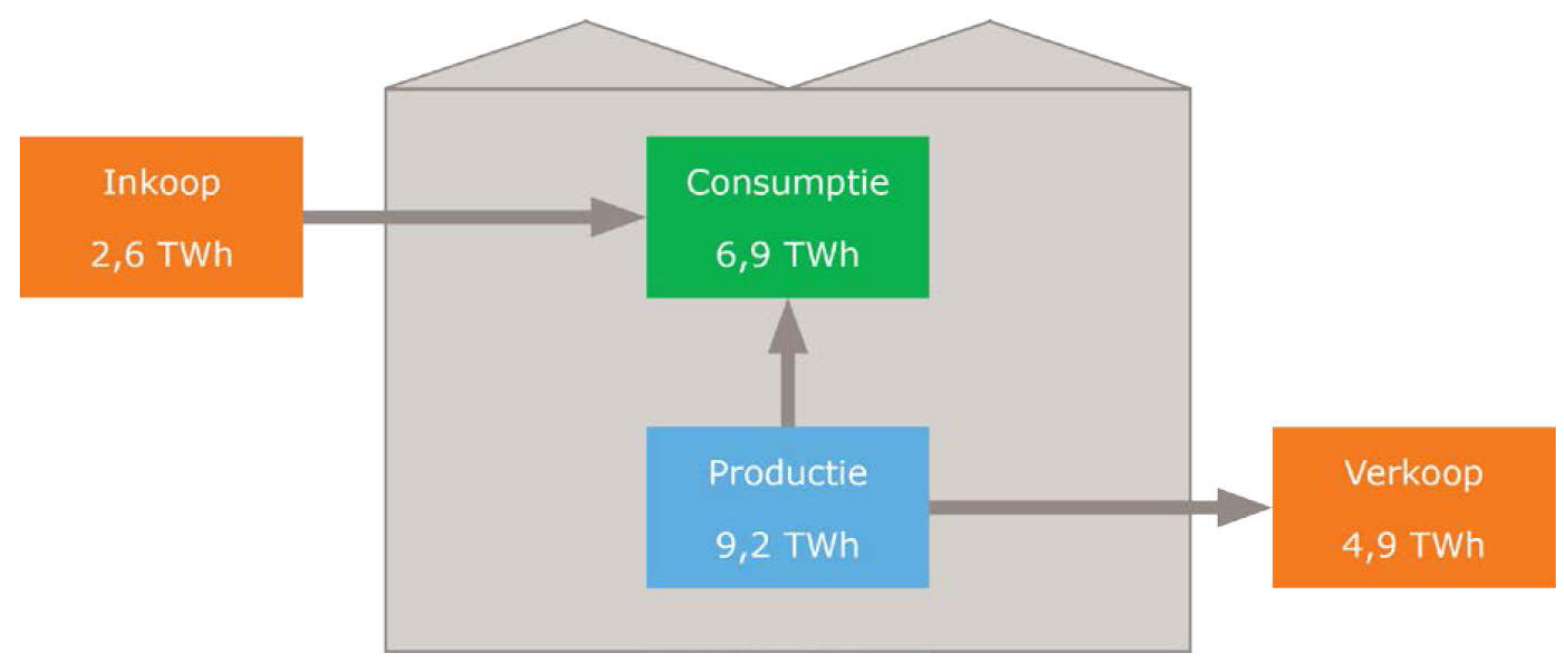

Figuur 4.6 Globale elektriciteitsbalans van de glastuinbouw in 2016 a)

a) Cijfers voorlopig. 
Productie

De elektriciteitsproductie door de glastuinbouw lag in de jaren 2008-2013 op gemiddeld bijna

12 miljard kWh. Hierna daalde dit naar ruim 9 miljard kWh in 2016. De daling kwam door de vermindering van het totale wkk-vermogen en door een kortere gebruiksduur. Behalve met aardgaswkk produceerde de glastuinbouw een geringe hoeveelheid duurzame elektriciteit met bio-wkk en met zonnecellen (hoofdstuk 3). De elektriciteitsproductie door de glastuinbouw voorzag in $20168 \%$ van de totale Nederlandse elektriciteitsconsumptie. Per $\mathrm{m}^{2}$ kas kwam de productie in 2016 uit op gemiddeld circa $100 \mathrm{kWh}$.

\section{Verkoop}

De verkoop is in de periode 2010-2014 gedaald van 8,4 tot 4,9 miljard kWh. De laatst 2 jaar is de verkoop niet veel verder gedaald maar lag in 2016 desalniettemin ruim $40 \%$ lager dan het topjaar 2010. De ontwikkeling over de hele periode vanaf 2010 hing samen met een daling van het totaal vermogen van het wkk-park in de glastuinbouw, de verslechterde spark spread, de verminderde warmtevraag per $\mathrm{m}^{2}$ van de glastuinbouw en de toename van de elektriciteitsconsumptie door de glastuinbouw.

Inkoop

De inkoop van elektriciteit bewoog zich in de periode 2010-2014 tussen de 2,2 en 2,5 miljard kWh per jaar. Na 2014 nam de inkoop toe tot ruim 2,6 miljard kWh in 2016. Deze ontwikkeling hangt samen met de intensivering van groeilicht $\left(\mathrm{W} / \mathrm{m}^{2}\right)$. Door de maximale warmtebenutting uit de wkk werd de extra elektriciteitsvraag gedeeltelijk ingekocht. Ook de daling van de elektriciteitsprijs (paragraaf 2.6) is van invloed.

Netto leverancier

Sinds 2006 wordt er meer elektriciteit verkocht dan er wordt ingekocht en is de glastuinbouw netto leverancier van elektriciteit. Deze netto-verkoop is in de periode 2010-2016 wel gedaald van 6,2 naar 2,3 miljard kWh. Dit is een daling van ruim $60 \%$ in 6 jaar.

\section{Consumptie}

De elektriciteitsconsumptie (productie plus inkoop en vermindert met de verkoop) van de sector bedroeg in 2016 naar schatting 6,9 miljard kWh. Dit is 6\% van de nationale consumptie. Over de gehele periode 2005-2016 nam de elektriciteitsconsumptie van de glastuinbouw toe, met een dip in 2010 en 2011 (figuur 4.5). De toename in de recentere periode 2010-2013 is minder sterk dan in de eerdere periode 2005-2009. Dit hangt samen met de krimp van het areaal vanaf 2010. De consumptiestijging komt vooral voort uit de toename van groeilicht (intensiteit) en in mindere mate uit verdere optimalisering van het kasklimaat, mechanisatie, automatisering en alternatieve energievoorzieningen (wkk en duurzame energie) (Van der Velden en Smit, 2013). Na 2012 lijkt de totale consumptie op sectorniveau te stabiliseren. Dit hangt samen met de krimp van het totaal areaal, de verdere groei van het areaal belichting bij de tomaat en verdere krimp van het areaal sierteeltgewassen met belichting. Per $\mathrm{m}^{2}$ kas lijkt de elektriciteitsconsumptie wel iets toe te nemen.

In de elektriciteitsconsumptie werd in 2016 voor ruim $60 \%$ voorzien door eigen productie met wkk. Het resterende deel werd ingekocht. In de periode 2005-2014 is de glastuinbouw in sterkere mate in de eigen elektriciteitsconsumptie gaan voorzien met wkk. Vanaf 2014 toont dit aandeel een daling. 


\section{$5 \quad$ Conclusies}

$\mathrm{CO}_{2}$-emissie

- De totale $\mathrm{CO}_{2}$-emissie nam in 2016 af met 0,2 Mton naar 5,6 Mton en ligt daarmee 0,6 Mton onder het oorspronkelijke doel voor 2020 (6,2 Mton) in de Meerjarenafspraak.

- In vergelijking met het $\mathrm{CO}_{2}$-doel voor 2020 na technische correctie (4,6 Mton) lag de $\mathrm{CO}_{2}$-emissie in 2016 1,0 Mton hoger.

- De $\mathrm{CO}_{2}$-emissie voor de teelt (exclusief verkoop elektriciteit) bleef in 2016 gelijk op een niveau van 4,3 Mton.

- De totale $\mathrm{CO}_{2}$-emissie lag in 2016 1,2 Mton (-18\%) onder het niveau van 1990. De glastuinbouw doet het dus beter dan de landelijke ontwikkeling van de $\mathrm{CO}_{2}$-emissie $(+9 \%)$.

- In de periode 2010-2016 daalde de totale $\mathrm{CO}_{2}$-emissie met 2,5 Mton. Gecorrigeerd voor de buitentemperatuur komt de daling uit op 2,2 Mton. Na temperatuur correctie is de $\mathrm{CO}_{2}$-emissie in de recentere periode 2014-2016 met 0,3 Mton gedaald.

- De $\mathrm{CO}_{2}$-emissie daalde door krimp van het areaal, minder verkoop elektriciteit, meer duurzame energie, meer inkoop elektriciteit, minder inkoop warmte en het saldo van de drie factoren intensivering, extensivering en energiebesparing.

- De daling in de periode 2010-2016 wordt voor 77\% verklaard door de eerste vijf factoren. Het resterende aandeel van $23 \%$ wordt verklaard door het saldo van de laatste drie factoren.

- Het saldo van de factoren intensivering, extensivering en energiebesparing was in de periode 20102016 groter dan in de periode 2010-2015. De intensivering heeft zich in 2016 doorontwikkeld terwijl de extensivering is verminderd. Dit betekent dat het effect van energiebesparing op de $\mathrm{CO}_{2}$-emissie in 2016 verder is toegenomen, ondanks de verdere toename van de netto-energiekosten.

Energie-efficiëntie

- In 2016 verbeterde de energie-efficiëntie met 1 procentpunt en bedroeg $41 \%$ ten opzichte van 1990.

- Deze verbetering kwam door lichte daling van het primair brandstofverbruik per $\mathrm{m}^{2}$ en een lichte toename van de fysieke productie per $\mathrm{m}^{2}$ met $0,5 \%$.

- In de periode 2008-2016 is de energie-efficiënte minder sterk verbeterd dan de periode voor 2008. Dit kwam doordat na 2008 het primair brandstofverbruik per $\mathrm{m}^{2}$ licht is toegenomen en door een beperkte groei van de fysieke productie per $\mathrm{m}^{2}$.

\section{Duurzame energie}

- Het aandeel duurzame energie groeide in 2016 met 0,6 procentpunt naar 5,5\% en het absolute gebruik groeide met 0,6 PJ (12\%) naar 5,4 PJ.

- Door een daling van het totale energiegebruik steeg het aandeel harder dan het absolute gebruik.

- Het aandeel duurzame energie in de glastuinbouw loopt 0,5 procentpunt achter op het landelijk aandeel dat 6,0\% bedraagt. De groei van duurzame energie in de glastuinbouw is wel sterker.

- In 2016 voorzag aardwarmte in 50\% van de toegepaste duurzame energie in de glastuinbouw, op afstand gevolgd door inkoop van duurzame elektriciteit (17\%), de inzet van zonne-energie (14\%) en biobrandstoffen ( $13 \%)$. De inkoop van duurzame warmte (5\%) en duurzaam gas ( $1 \%)$ bleef beperkt.

- De groei zat vooral bij aardwarmte in inkoop duurzame elektriciteit.

- Het groeitempo nam in 2016 af. Dit kwam door technische problemen bij aardwarmteprojecten en minder nieuwe duurzame energieprojecten. Ook speelden de relatief lage energieprijzen een rol. De inzet van de duurzame energievormen anders dan aardwarmte en inkoop duurzame elektriciteit groeit al jaren nauwelijks door.

- Van de toegepaste duurzame energie werd in 2016 77\% door de sector zelf geproduceerd en werd $23 \%$ buiten de sector ingekocht. Van de duurzame energie die door de sector is toegepast, werd $6 \%$ gekocht bij andere glastuinbouwbedrijven die duurzame energie produceren.

- Het gebruik van duurzame energie bestond voor $82 \%$ uit warmte en $18 \%$ uit elektriciteit. Duurzame warmte werd voor $93 \%$ zelf geproduceerd en duurzame elektriciteit voor $98 \%$ ingekocht. 
- In 2016 pasten 151 bedrijven op 978 hectare duurzame energie (exclusief inkoop via openbaar netten) toe. Dit is ruim een tiende van het totaal areaal glastuinbouw.

- Meer dan $80 \%$ van de duurzame energie wordt toegepast door grotere bedrijven met een glasareaal van meer dan 4 ha. De gemiddelde bedrijfsomvang bij duurzame energie is 6,5 hectare.

- Het gebruik van externe $\mathrm{CO}_{2}$ nam vanaf 2013 licht toe en bedroeg in 2016 0,55 Mton.

Energiekosten en energiegebruik

- De netto-energiekosten zijn in de periode 2013-2016 sterk gedaald en lagen in 2016 zo'n 35\% onder het niveau van 2013. De daling kwam vooral door lagere prijzen en door een lager energiegebruik. Zowel de kosten voor de inkoop als de opbrengsten voor de verkoop daalden. De kosten voor inkoop daalden echter sterker.

- De warmteconsumptie per $\mathrm{m}^{2}$ is in de periode 2006-2014 afgenomen en de elektriciteitsconsumptie nam toe. Deze verschuiving kwam vooral door intensivering in de vorm van groeilicht. Vanaf 2014 trad dit intensiveringseffect ook op maar lijkt door veranderingen in de sectorstructuur te stabiliseren.

Warmtekrachtkoppeling, inkoop warmte en elektriciteitsbalans

- Het totale vermogen van het wkk-park in de glastuinbouw was per eind 2016 zo'n 2.700-2.800 MWe en laat sinds 2012 een daling zien.

- De afname van het totale vermogen hangt vooral samen met de krimp van het areaal, de verslechterde spark spread en de toename van duurzame energie.

- De gemiddelde gebruiksduur van wkk is in de periode 2011-2016 met bijna 20\% gedaald.

- De elektriciteitsproductie door wkk is in de periode 2013-2016 met zo'n 23\% gedaald tot een niveau van ruim 9 miljard kWh in 2016 en dekte $8 \%$ van de nationale consumptie.

- De verkoop van elektriciteit nam in de periode 2010-2016 met bijna 40\% af en bedroeg in 2016 4,9 miljard kWh; in de jaren 2015 en 2016 bleek verdere afname beperkt van omvang.

- De inkoop van elektriciteit beweegt zich in de periode 2010-2014 tussen de 2,2 en 2,5 miljard kWh per jaar. De jaren 2015 en 2016 lieten een toename van de inkoop zien tot 2,6 miljard kWh in 2016.

- De netto-verkoop van elektriciteit is in de periode 2010-2016 gedaald van 6,2 tot 2,3 miljard kWh. Dit is en daling van ruim $60 \%$ in 6 jaar.

- De elektriciteitsconsumptie bedraagt in 2016 naar schatting ruim 7 miljard kWh. Dit komt overeen $6 \%$ van de nationale consumptie.

- De elektriciteitsconsumptie op sectorniveau nam in de periode 2005-2013 toe en lijkt in de jaren daarna te stabiliseren. De toename hing samen met de groei van het areaal belichting bij de groente (tomaat) en krimp van het areaal sierteeltgewassen met belichting. Per $\mathrm{m}^{2}$ lijkt de elektriciteitsconsumptie de laatste jaren wel iets toe te nemen.

- In 2016 werd op circa twee derde van het sectorareaal door tuinders een wkk toegepast. Hiermee werd op nationaal niveau 1,8 Mton $\mathrm{CO}_{2}$-emissie vermeden. Dit is 0,5 Mton minder dan 2008, het jaar met hoogste emissiereductie door wkk van de tuinders.

- De hoeveelheid ingekochte warmte bestond vooral uit restwarmte van elektriciteitscentrales en industrieën en nam in 2015 en 2016 na vele jaren van teruggang weer iets toe. De warmte-inkoop had in 2016 een aandeel in het totale energiegebruik van de glastuinbouw van bijna $4 \%$.

Protocol

- De conceptuele methodiek behoeft geen aanpassing.

- In de werkwijze zijn kwaliteitsverbeteringen mogelijk. Dit betreft met name verbeteringen bij het glastuinbouw areaal in de Landbouwtelling en de beschikbaarheid van informatie van stimuleringsmaatregelen vanuit de overheid.

- Bij de Landbouwtelling is in de glastuinbouw sprake van een non-respons die moeilijk is bij te schatten.

- De stimuleringsmaatregelen, met name de regeling Stimulering Duurzame Energieproductie, is op steeds meer bedrijven van toepassing maar deze data zijn vooralsnog niet toegankelijk voor het onderzoek. 


\section{Literatuur en websites}

Brief van de Staatssecretaris van Economische Zaken de heer Martijn van Dam aan de voorzitter van de Tweede Kamer betreffende Evaluatie $\mathrm{CO}_{2}$-suring in de glastuinbouw, dd. 6 juli 2017.

Convenant $\mathrm{CO}_{2}$ emissieruimte binnen het $\mathrm{CO}_{2}$ sectorsysteem glastuinbouw voor de periode 20132020. 2011.

Energieakkoord voor duurzame groei, SER, 2013.

Hernieuwbare energie in Nederland t/m 2016, CBS, Den Haag, Statline versie 30 juni 2017.

Meerjarenafspraak Energietransitie Glastuinbouw 2014-2020, Den Haag, 2014.

Velden, N. van der en P. Smit, Groei elektriciteitsconsumptie glastuinbouw; Hoe verder?. Rapport 2013-022. LEI Wageningen UR, 2013.

Velden, N. van der en P. Smit, Energiemonitor van de Nederlandse Glastuinbouw 2015. Rapport 2016-099. LEI Wageningen UR, 2016.

Velden, N. van der en P. Smit, Prognose $\mathrm{CO}_{2}$-emissie glastuinbouw 2020. Rapport 2016-067. Wageningen Economic Research, 2017.

Velden, N. van der en P. Smit, Effect intensivering, extensivering en energiebesparing op $\mathrm{CO}_{2}$-emissie Nederlandse glastuinbouw. Rapport 2017-060. Wageningen Economic Research, 2017.

Velden, N. van der, Protocol Energiemonitor Glastuinbouw; Versie tot en met 2016. Nota 2017-094b. Wageningen Economic Research, 2017.

www.emissieautoriteit. nl

www. kasalsenergiebron.nl

www.statline.nl 


\section{Bijlage 1 Definities, methode en bronnen}

\section{B1.1 Definities}

\section{Protocol}

De definities, methodiek en bronnen zijn vastgelegd in het Protocol Energiemonitor Glastuinbouw (Van der Velden en Smit, 2017) en worden in deze bijlage op hoofdlijnen toegelicht.

\section{Definities van indicatoren}

De energie-efficiëntie is het primair brandstofverbruik per eenheid product van de productieglastuinbouw, uitgedrukt in procenten van het niveau in het basisjaar.

De $\mathrm{CO}_{2}$-emissie wordt uitgedrukt in Mton per jaar en wordt bepaald volgens de IPCC-methode en heeft betrekking op de gehele glastuinbouwsector. Onderscheid wordt gemaakt naar de totale $\mathrm{CO}_{2}$-emissie van de sector en de $\mathrm{CO}_{2}$-emissie voor de teelt (exclusief verkoop elektriciteit).

Het aandeel duurzame energie is het quotiënt van de werkelijk gebruikte hoeveelheid duurzame energie en het totale netto-energiegebruik (inkoop minus verkoop) in de gehele glastuinbouw, uitgedrukt in procenten.

De definities van de indicatoren verschillen ten aanzien van het areaal glas en het begrip energie.

\section{Areaal}

De glastuinbouw omvat het areaal productieglastuinbouw en het areaal uitgangsmateriaal (figuur B.1). De productieglastuinbouw bestaat uit de subsectoren groente, bloemen en potplanten. Het uitgangsmateriaal betreft de teelt van zaden en stek en de opkweek van jonge planten. Uitgangsmateriaal wordt gezien als toelevering (binnen en buiten de glastuinbouw) en niet als primair productie. Daarom blijft het areaal met uitgangsmateriaal buiten beschouwing bij de energieefficiëntie. De $\mathrm{CO}_{2}$-emissie heeft betrekking op de gehele glastuinbouw, inclusief het areaal uitgangsmateriaal.

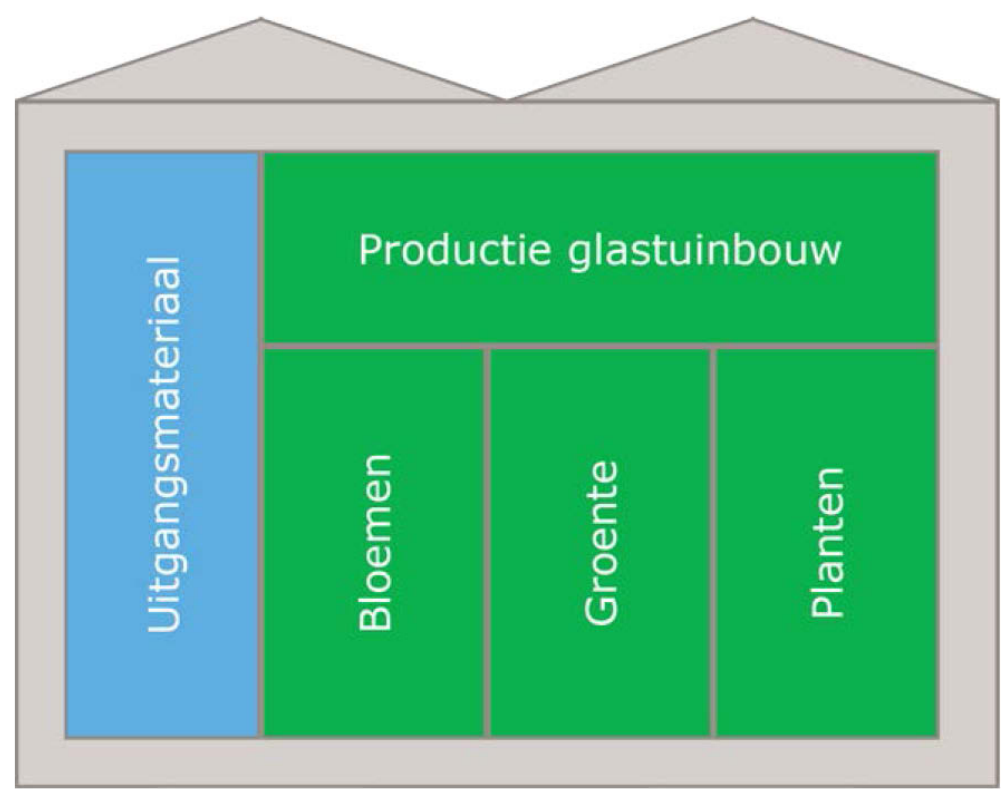

Figuur B.1 Schematische weergave areaal glastuinbouw en productieglastuinbouw 


\section{Energie}

Het energiegebruik in de glastuinbouw omvat meerdere soorten (figuur B.2). Aardgas, olie, warmte en elektriciteit wordt ingekocht en elektriciteit en warmte verkocht. Duurzame energie wordt ingekocht, geproduceerd en verkocht. Dit alles is op verschillende wijzen te sommeren.

Sommatie op basis van energie-inhoud resulteert in het kengetal totaal energiegebruik. De verkoop van energie wordt hierbij in mindering gebracht.

Voor het primair brandstofverbruik wordt de hoeveelheid fossiele brandstof bepaald die nodig is voor de productie van de afzonderlijke energiesoorten. Aardgas en overige fossiele brandstoffen zijn primaire brandstoffen. De inkoop van elektriciteit wordt herleid tot de hoeveelheid brandstof die daarvoor nodig is in een gemiddelde Nederlandse elektriciteitscentrale zonder warmtelevering. Voor de verkoop van elektriciteit geldt hetzelfde, maar dit wordt in mindering gebracht. De ingekochte warmte komt van elektriciteitscentrales (restwarmte), industrie en van energiebedrijven. Door de gecombineerde productie van elektriciteit en warmte ligt de elektriciteitsproductie lager. Voor de geleverde warmte wordt de extra hoeveelheid brandstof berekend die nodig is om de derving van de elektriciteitsproductie te compenseren.

De $\mathrm{CO}_{2}$-emissie wordt bepaald op basis van de IPCC-methode. Hierbij wordt alleen de werkelijk verstookte fossiele brandstof op glastuinbouwbedrijven in beschouwing genomen. Onderscheid wordt gemaakt naar de totale $\mathrm{CO}_{2}$-emissie en de $\mathrm{CO}_{2}$-emissie voor de teelt. De totale $\mathrm{CO}_{2}$-emissie heeft betrekking op alle fossiele brandstoffen inclusief voor de productie van elektriciteit op de glastuinbouwbedrijven. De $\mathrm{CO}_{2}$-emissie voor de teelt is de totale $\mathrm{CO}_{2}$-emissie verminderd met de emissie die gerelateerd is aan door de glastuinbouw verkochte elektriciteit geproduceerd met aardgasgestookte wkk.

Het primair brandstofverbruik is de grondslag voor de energie-efficiëntie. De $\mathrm{CO}_{2}$-emissie wordt bepaald op basis van het werkelijke gebruik van fossiele brandstoffen (IPCC-methode).

Het totale energiegebruik wordt gebruikt voor het bepalen van het aandeel duurzame energie. Netto wil zeggen inkoop minus verkoop.

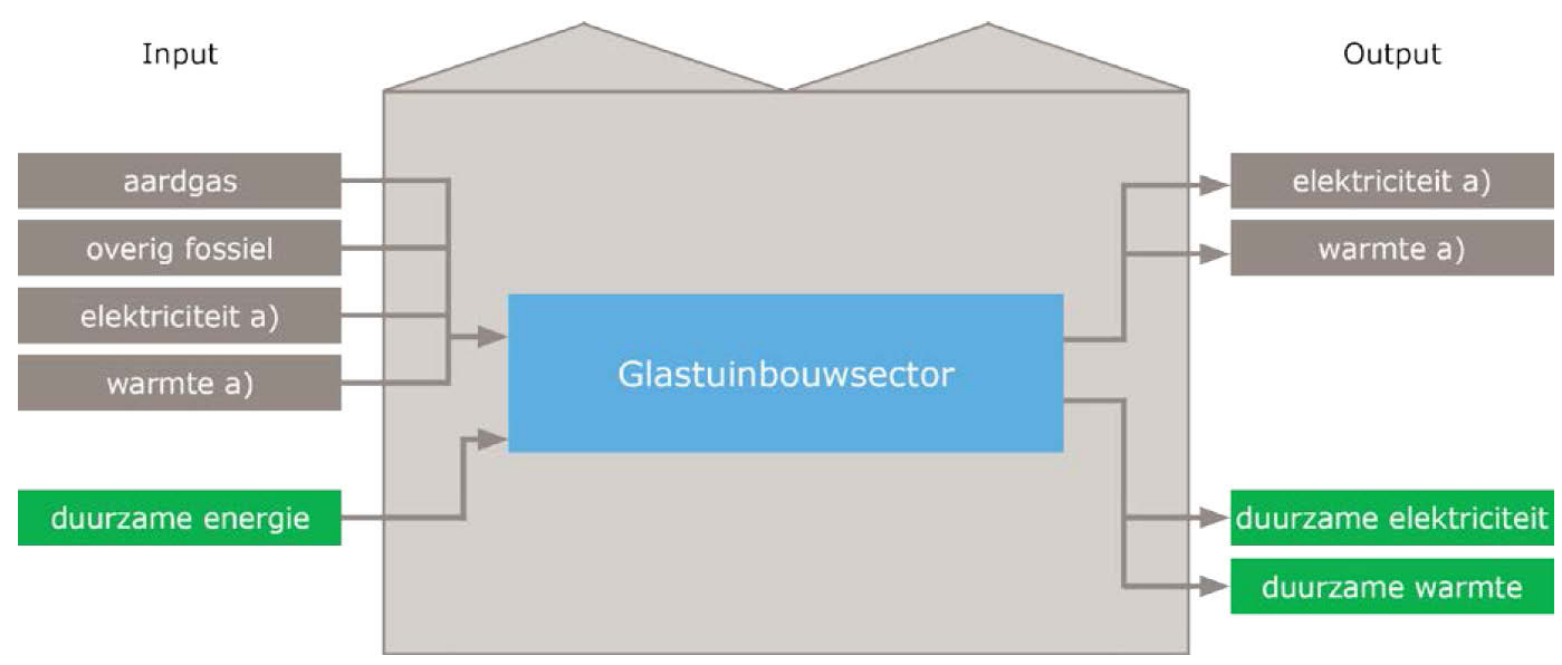

Figuur B.2 Energie input en output van de glastuinbouwsector

a) Fossiele bron.

\section{Duurzame energie}

Duurzame energie omvat energie uit zon, wind, waterkracht, aardwarmte en biobrandstof via een hernieuwbaar proces. Hernieuwbaar betekent dat er geen fossiele brandstof wordt gebruikt en er netto geen $\mathrm{CO}_{2}$-emissie ontstaat. Het aandeel duurzame energie heeft betrekking op het werkelijke gebruik in de glastuinbouw. Duurzaam geproduceerde energie voor gebruik buiten de sector telt niet mee. 
Voorbeelden hiervan zijn op biobrandstof gestookte wkk waarvan de geproduceerde elektriciteit (deels) wordt verkocht buiten de sector of aardwarmte dat wordt verkocht buiten de sector. Verkoop van duurzame energie binnen de sector telt wel mee evenals ingekochte duurzame elektriciteit en warmte van buiten de sector.

Bij het bepalen van het totale energiegebruik in de glastuinbouw op basis van energie-inhoud telt de duurzame energie wel mee. Dit is niet het geval bij het bepalen van het primair brandstofverbruik en de $\mathrm{CO}_{2}$-emissie.

Temperatuurcorrectie

Het energiegebruik verschilt van jaar tot jaar, mede door verschillen in buitentemperatuur. Het primair brandstofverbruik en dus ook de energie-efficiëntie wordt hiervoor gecorrigeerd. Bij het totale energiegebruik en de $\mathrm{CO}_{2}$-emissie vindt geen temperatuurcorrectie plaats.

\section{B1.2 Methode en bronnen}

Voor het kwantificeren van de indicatoren moeten de totale energie-input en - output van de glastuinbouw en de productieglastuinbouw opgesplitst naar afzonderlijke energiesoorten (figuur B.2) worden vastgesteld. Voor de energie-efficiëntie betreft dit ook de fysieke productie. Daarnaast is informatie nodig voor het opstellen van de elektriciteitsbalans. De belangrijkste informatiebronnen zijn:

- energieregistraties van het Milieu Project Sierteelt (MPS)

- energieregistraties van Groeiservice c.q. GreelinQdata

- energieregistraties van groepen tuinders

- energieregistraties van groentebedrijven van het Bedrijveninformatienet van het Wageningen Economic Research

- inkoop restwarmte van de leveranciers

- elektrisch vermogen van wk-installaties van energiebedrijven en tuinders via de inventarisatie door Energy Matters

- elektrisch vermogen en gebruiksduur van wkk van tuinders op basis van informatie van Energy Matters, energiebedrijven en groepen tuinders en het Bedrijveninformatienet van Wageningen Economic Research

- veilingomzetten bloemen en planten van de FloraHolland en Plantion

- prijsinformatie bloemen en planten van FloraHolland

- fysieke productie vruchtgroenten van het Bedrijveninformatienet van Wageningen Economic Research, accountants, telersverenigingen en groepen tuinders

- areaalgegevens en informatie over het gebruik van wkk uit de Landbouwtelling gepubliceerd door het Centraal Bureau voor de Statistiek (CBS)

- areaalgegevens belichting vruchtgroenten van adviseurs en telersverenigingen

- verkoopinformatie duurzame elektriciteit van energiebedrijven

- leveranciers van installaties en adviseurs.

Energie-input en -output

Figuur B.2 geeft de energie-input en -output van de glastuinbouw schematisch weer. MPS, GreelinQdata en andere bronnen bieden informatie over het energiegebruik per energiesoort in de subsectoren groente, bloemen, potplanten en uitgangsmateriaal. De bedrijfsgegevens van deze bronnen zijn ingedeeld naar gewas(groep) conform de Landbouwtelling van het CBS. Met behulp van de areaalgegevens per gewas(groep) van de Landbouwtelling is de energie-informatie per gewas(groep) geaggregeerd naar sectorniveau. Daarnaast is informatie beschikbaar over de warmteinkoop door de glastuinbouw.

Wkk en elektriciteitsbalans

De glastuinbouw produceert op grote schaal elektriciteit met wkk. De elektriciteitsproductie van deze installaties is het product van het totaal elektrisch vermogen in de glastuinbouw en de gemiddelde gebruiksduur. 
Voor het in kaart brengen van een elektriciteitsbalans zijn de inkoop, verkoop en productie gekwantificeerd, waarna de elektriciteitsconsumptie is berekend. Bij dit laatste dient opgemerkt te worden dat de consumptie de sluitpost is waarin alle eventuele fouten bij de schatting van de inkoop, verkoop en productie doorwerken. De informatie over de consumptie moet daardoor gezien worden als een globale indicatie.

Inventarisatie duurzame energie

Statistieken over het gebruik van duurzame energiebronnen zijn nog nauwelijks beschikbaar. Duurzame energie is in kaart gebracht middels een inventarisatie van de projecten. Voor inkoop duurzame elektriciteit is informatie verzameld over de verkoop aan de glastuinbouw bij energiebedrijven.

Fysieke productie De glastuinbouw brengt vele producten voort. De fysieke productie wordt uitgedrukt in verschillende eenheden: tomaten en paprika per kg, komkommer per stuk, bloemen per stuk of per bos en potplanten per stuk. Sommatie van deze eenheden vindt indirect plaats. Hierbij wordt uitgegaan van de totale omzet aan glastuinbouwproducten per jaar. Omzetverschillen tussen jaren hangen samen met mutaties in prijs en in fysieke productie. De fysieke productie wordt bepaald door de jaaromzet te corrigeren voor de gemiddelde prijsmutatie van de glastuinbouwproducten.

Voor prijsmutaties bij groenten is geen databron beschikbaar. Daarom is voor deze subsector informatie over de ontwikkeling van de fysieke productie verzameld van de belangrijkste gewassen (tomaat, paprika en komkommer). 


\section{Bijlage 2 Kenmerken en energie-indicatoren glastuinbouw}

\begin{tabular}{|c|c|c|c|c|c|c|c|c|c|c|c|c|c|}
\hline Grootheid & Eenheid & 1980 & 1990 & 2000 & 2005 & 2008 & 2010 & 2011 & 2012 & 2013 & 2014 & 2015 & $2016 v$ \\
\hline Areaal glastuinbouw & ha & 8.755 & 9.768 & 10.528 & 10.537 & 10.165 & 10.307 & 10.249 & 9.962 & 9.817 & 9.488 & 9.206 & 9.278 \\
\hline Areaal productieglastuinbouw & ha & 8.527 & 9.368 & 10.036 & 10.028 & 9.623 & 9.757 & 9.687 & 9.405 & 9.235 & 8.876 & 8.609 & 8.635 \\
\hline Buitentemperatuur g) & graaddagen & 3.246 & 2.680 & 2.659 & 2.765 & 2.784 & 3.321 & 2.622 & 2.879 & 3.078 & 2.385 & 2.686 & 2.785 \\
\hline Lichtsom e) & $\%$ norm & 95 & 105 & 97 & 107 & 104 & 108 & 106 & 102 & 104 & 108 & 111 & 108 \\
\hline \multirow[t]{2}{*}{ Totaal energie a)c) } & PJ & - & - & 136,7 & 128,1 & 115,0 & 127,1 & 115,9 & 111,6 & 112,9 & 96,1 & 99,4 & 98,8 \\
\hline & $\mathrm{MJ} / \mathrm{m}^{2}$ & - & - & 1.299 & 1.216 & 1.132 & 1.233 & 1.130 & 1.121 & 1.150 & 1.013 & 1.079 & 1.065 \\
\hline \multirow[t]{2}{*}{ Primair brandstof b)d) } & $10^{6} \mathrm{~m}^{3}$ a.e. & 3.488 & 4.195 & 4.276 & 3.860 & 2.571 & 2.565 & 2.594 & 2.517 & 2.544 & 2.393 & 2.397 & 2.370 \\
\hline & $\mathrm{m}^{3}$ a.e. $/ \mathrm{m}^{2}$ & 40,9 & 44,8 & 42,6 & 38,5 & 26,7 & 26,3 & 26,8 & 26,8 & 27,5 & 27,0 & 27,8 & 27,5 \\
\hline Fysieke productie per $\mathrm{m}^{2} \mathrm{~b}$ ) & $\% 1990$ & - & 100 & 114 & 128 & 137 & 137 & 140 & 139 & 141 & 148 & 147 & 148 \\
\hline Energie-efficiëntie b), d) & \% 1990 & - & 100 & 84 & 67 & 44 & 43 & 43 & 43 & 44 & 41 & 42 & 41 \\
\hline \multirow[t]{2}{*}{ Fossiel brandstof totaal a) c) } & $10^{6} \mathrm{~m}^{3}$ a.e. & - & 3.808 & 3.710 & 3.596 & 3.944 & 4.502 & 4.128 & 3.847 & 3.847 & 3.163 & 3.213 & 3.123 \\
\hline & $\mathrm{m}^{3}$ a.e. $/ \mathrm{m}^{2}$ & - & 39,0 & 35,2 & 34,1 & 38,8 & 43,7 & 40,3 & 38,6 & 39,2 & 33,3 & 34,9 & 33,7 \\
\hline \multirow[t]{2}{*}{ Fossiel brandstof teelt a) c) } & $10^{6} \mathrm{~m}^{3}$ a.e. & - & 3.808 & 3.670 & 3.398 & 2.864 & 3.227 & 2.895 & 2.802 & 2.804 & 2.369 & 2.419 & 2.382 \\
\hline & $\mathrm{m}^{3}$ a.e. $/ \mathrm{m}^{2}$ & - & 39,0 & 34,9 & 32,3 & 28,2 & 31,3 & 28,2 & 28,1 & 28,6 & 25,0 & 26,3 & 25,7 \\
\hline \multirow[t]{2}{*}{$\mathrm{CO}_{2}$-emissie totaal a) c) } & Mton & - & 6,8 & 6,7 & 6,5 & 7,1 & 8,1 & 7,4 & 6,9 & 6,9 & 5,7 & 5,8 & 5,6 \\
\hline & $\% 1990$ & - & 100 & 97 & 94 & 104 & 118 & 108 & 101 & 101 & 83 & 84 & 82 \\
\hline \multirow[t]{2}{*}{$\mathrm{CO}_{2}$-emissie teelt a) c) } & Mton & - & 6,8 & 6,6 & 6,1 & 5,1 & 5,8 & 5,2 & 5,0 & 5,0 & 4,3 & 4,3 & 4,3 \\
\hline & $\% 1990$ & - & 100 & 96 & 89 & 75 & 85 & 76 & 74 & 74 & 62 & 64 & 63 \\
\hline \multirow[t]{2}{*}{$\mathrm{CO}_{2}$-emissie Nederland f) } & Mton & - & 170,8 & 183,0 & 191,0 & 190,7 & 199,4 & 186,9 & 184,4 & 182,9 & 177,0 & 185,6 & 187,0 \\
\hline & $\% 1990$ & - & 100 & 107 & 112 & 112 & 117 & 109 & 108 & 107 & 104 & 108 & 109 \\
\hline Aandeel duurzaam a), c) & $\%$ & - & - & 0,1 & 0,5 & 1,4 & 1,9 & 2,1 & 2,5 & 2,9 & 4,3 & 4,8 & 5,5 \\
\hline Aandeel duurzaam Nederland f) & $\%$ & & & 1,6 & 2,5 & 3,6 & 3,9 & 4,5 & 4,7 & 4,8 & 5,5 & 5,8 & 6,0 \\
\hline
\end{tabular}

$v=$ voorlopige cijfers; $-=$ cijfers niet beschikbaar

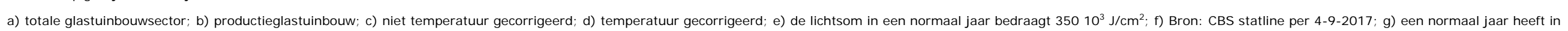
de periode 2010-2016 gemiddeld 2922 graaddagen 


\section{Bijlage 3 Energiegebruik glastuinbouw (totale glastuinbouwareaal en niet gecorrigeerd voor temperatuur) a)}

\begin{tabular}{|c|c|c|c|c|c|c|c|c|c|c|c|c|c|}
\hline Energiesoort & Eenheid & 1980 & 1990 & 2000 & 2005 & 2008 & 2010 & 2011 & 2012 & 2013 & 2014 & 2015 & $2016 v$ \\
\hline Aardgas & miljoen $\mathrm{m}^{3}$ & 3.352 & 3.778 & 3.709 & 3.593 & 3.941 & 4.500 & 4.127 & 3.846 & 3.846 & 3.162 & 3.212 & 3.122 \\
\hline Overig fossiel b) & miljoen $\mathrm{m}^{3}$ a.e. & - & 30 & 1 & 3 & 3 & 2 & 1 & 1 & 1 & 1 & 1 & 1 \\
\hline Restwarmte c) & PJ & 0 & 1,2 & 5,6 & 4,0 & 3,3 & 3,6 & 3,1 & 3,4 & 3,4 & 3,0 & 3,3 & 3,6 \\
\hline Wk-warmte energiebedrijven & PJ & 0 & 0,7 & 9,3 & 5,1 & 2,8 & 1,7 & 1,5 & 1,1 & 0,7 & 0,4 & 0,2 & 0,1 \\
\hline \multicolumn{14}{|l|}{ Elektriciteit } \\
\hline - inkoop totaal & miljoen $\mathrm{kWh}$ & - & - & 1.479 & 2.626 & 2.320 & 2.169 & 2.204 & 2.213 & 2.488 & 2.206 & 2.507 & 2.624 \\
\hline - wv groen & miljoen $\mathrm{kWh}$ & - & - & 0 & 55 & 113 & 175 & 154 & 160 & 140 & 150 & 210 & 260 \\
\hline - verkoop & miljoen kWh & - & - & 266 & 1298 & 7.083 & 8.397 & 8.121 & 6.889 & 6.873 & 5.244 & 5.245 & 4.896 \\
\hline - wv groen & miljoen $\mathrm{kWh}$ & - & - & - & - & 18 & 21 & 20 & 19 & 22 & 27 & 28 & 28 \\
\hline - netto-inkoop & miljoen kWh & - & - & 1.213 & 1.328 & -4.763 & -6.228 & -5.917 & -4.676 & -4.385 & -3.038 & -2.738 & -2.272 \\
\hline Duurzame energie & PJ & - & - & 0,1 & 0,6 & 1,7 & 2,4 & 2,4 & 2,8 & 3,3 & 4,1 & 4,8 & 5,4 \\
\hline Totaal energie & PJ & - & - & 136,7 & 128,1 & 115,0 & 127,1 & 115,9 & 111,7 & 112,9 & 96,6 & 99,4 & 98,8 \\
\hline Totaal fossiel & miljoen $\mathrm{m}^{3}$ a.e. & - & 3.808 & 3.710 & 3.596 & 3.944 & 4.502 & 4.128 & 3.847 & 3.847 & 3.163 & 3.213 & 3.123 \\
\hline
\end{tabular}

$\mathrm{v}=$ voorlopige cijfers; - = cijfers niet beschikbaar

a) de verkoop van warmte komt voor sinds 2007 maar is in deze tabel niet opgenomen, omdat het een zeer beperkte hoeveelheid betreft; b) zware en lichte olie en propaan; c) exclusief aandeel duurzame warmte. 


\section{Bijlage 4 Gebruik en reductie $\mathrm{CO}_{2}$-emissie per duurzame energiebron en inkoop $\mathrm{CO}_{2}$}

\begin{tabular}{|c|c|c|c|c|c|c|c|c|c|c|c|c|c|}
\hline \multirow[t]{3}{*}{ Duurzame energiebron } & \multirow{2}{*}{\multicolumn{5}{|c|}{ Areaal c), aantal bedrijven c), vermogen c) en/ of hoeveelheid }} & \multicolumn{8}{|c|}{ Reductie $\mathrm{CO}_{2}$-emissie (Mton) } \\
\hline & & & & & & \multicolumn{4}{|c|}{ sector/I PCC } & \multicolumn{4}{|c|}{ nationaal/ primair brandstof } \\
\hline & 2010 & 2012 & 2014 & 2015 & $2016 v$ & 2010 & 2014 & 2015 & $2016 v$ & 2010 & 2014 & 2015 & $2016 v$ \\
\hline \multirow[t]{2}{*}{ Aardwarmte } & 1 bedrijf & 10 bedrijven & 31 bedrijven & 34 bedrijven & 43 bedrijven & 0,015 & 0,095 & 0,133 & 0,149 & 0,014 & 0,086 & 0,120 & 0,133 \\
\hline & 21 ha & 73 ha & 445 ha & 459 ha & 503 ha & & & & & & & & \\
\hline \multicolumn{14}{|l|}{ Zonne-energie } \\
\hline \multirow[t]{2}{*}{ - warmte a) } & 55 bedrijven & 63 bedrijven & 62 bedrijven & 64 bedrijven & 61 bedrijven & 0,042 & 0,044 & 0,040 & 0,042 & 0,014 & 0,016 & 0,016 & 0,015 \\
\hline & 216 ha & 229 ha & 221 ha & 211 ha & 205 ha & & & & & & & & \\
\hline \multirow{2}{*}{ - elektriciteit } & 1 bedrijf & 1 bedrijf & 1 bedrijf & 3 bedrijven & 6 bedrijven & 0 & 0 & 0 & 0 & $<0,001$ & $<0,001$ & $<0,001$ & 0,001 \\
\hline & 8 ha & 8 ha & 8 ha & 65 ha & 149 ha & & & & & & & & \\
\hline \multicolumn{14}{|l|}{ Biobrandstoffen } \\
\hline \multirow[t]{2}{*}{ - warmte } & 22 bedrijven & 26 bedrijven & 28 bedrijven & 28 bedrijven & 32 bedrijven & & & & & & & & \\
\hline & 80 ha & 91 ha & 117 ha & 117 ha & 130 ha & 0,009 & 0,022 & 0,023 & 0,026 & 0,009 & 0,021 & 0,021 & 0,025 \\
\hline \multirow{3}{*}{ - warmte plus elektriciteit b) } & 4 bedrijven & 3 bedrijven & 4 bedrijven & 4 bedrijven & 4 bedrijven & & & & & & & & \\
\hline & 45 ha & 23 ha & 19 ha & 19 ha & 19 ha & 0,009 & 0,010 & 0,011 & 0,011 & 0,019 & 0,024 & 0,024 & 0,025 \\
\hline & $5 \mathrm{MW}_{\mathrm{e}}$ & $4 \mathrm{MW}_{\mathrm{e}}$ & $4 \mathrm{MW}_{\mathrm{e}}$ & $4 \mathrm{MW}_{\mathrm{e}}$ & $4 \mathrm{MW}_{\mathrm{e}}$ & & & & & & & & \\
\hline Inkoop duurzame elektriciteit & $17510^{6} \mathrm{kWh}$ & $16010^{6} \mathrm{kWh}$ & $15010^{6} \mathrm{kWh}$ & $20010^{6} \mathrm{kWh}$ & $26010^{6} \mathrm{kWh}$ & 0 & 0 & 0 & 0 & 0,082 & 0,071 & 0,094 & 0,122 \\
\hline \multicolumn{14}{|l|}{ Inkoop duurzame warmte } \\
\hline - centraal & - & - & - & - & - & 0,012 & 0,002 & $<0,001$ & $<0,001$ & 0,012 & 0,002 & $<0,001$ & $<0,001$ \\
\hline \multirow[t]{2}{*}{ - decentraal } & 6 bedrijven & 7 bedrijven & 7 bedrijven & 7 bedrijven & 7 bedrijven & 0,008 & 0,013 & 0,013 & 0,014 & 0,007 & 0,012 & 0,013 & 0,013 \\
\hline & 30 ha & 33 ha & 33 ha & 33 ha & 33 ha & & & & & & & & \\
\hline Inkoop duurzaam gas & $110^{6} \mathrm{~m}^{3}$ & $110^{6} \mathrm{~m}^{3}$ & $110^{6} \mathrm{~m}^{3}$ & $110^{6} \mathrm{~m}^{3}$ & $110^{6} \mathrm{~m}^{3}$ & 0,002 & 0,002 & 0,002 & 0,002 & 0,002 & 0,002 & 0,002 & 0,002 \\
\hline Totaal duurzame energie & d) & d) & d) & d) & d) & 0,096 & 0,188 & 0,225 & 0,244 & 0,159 & 0,233 & 0,290 & 0,337 \\
\hline Inkoop $\mathrm{CO}_{2}$ & 0,51-0,54 Mton & $0,48-0,51$ Mton & $0,51-0,55$ Mton & $0,51-0,55$ Mton & 0,54-0,57 Mton & \# & \# & \# & \# & \# & \# & \# & \# \\
\hline
\end{tabular}




\section{Bijlage 5 Gebruik en reductie $\mathrm{CO}_{2}$-emissie wkk en inkoop warmte}

\begin{tabular}{|c|c|c|c|c|c|c|c|c|c|c|c|c|c|}
\hline \multirow[t]{3}{*}{ Wkk-vorm } & \multirow{2}{*}{\multicolumn{5}{|c|}{$\begin{array}{l}\text { Areaal (ha) b) } \\
\text { vermogen b) }\end{array}$}} & \multicolumn{8}{|c|}{ Reductie $\mathrm{CO}_{2}$-emissie (Mton) } \\
\hline & & & & & & \multicolumn{4}{|c|}{ sector/ I PCC } & \multicolumn{4}{|c|}{ nationaal/ primair brandstof } \\
\hline & 2010 & 2012 & 2014 & 2015 & $2016 v$ & 2010 & 2014 & 2015 & $2016 v$ & 2010 & 2014 & 2015 & $2016 v$ \\
\hline Wkk-tuinder & $2.887 \mathrm{MW}_{\mathrm{e}}$ & $2.895 \mathrm{MW}_{\mathrm{e}}$ & $2.822 \mathrm{MW}_{\mathrm{e}}$ & $2.748 \mathrm{MW}_{\mathrm{e}}$ & $2.771 \mathrm{MW}_{\mathrm{e}}$ & $-3,23$ & $-2,73$ & $-2,73$ & $-2,48$ & 2,33 & 1,97 & 1,97 & 1,79 \\
\hline Restwarmte a) & 430-450 ha & 445-465 ha & 455-465 ha & 470-480 ha & 480-490 ha & 0,201 & 0,164 & 0,181 & 0,198 & 0,143 & 0,119 & 0,133 & 0,146 \\
\hline $\begin{array}{l}\text { Wk-warmte } \\
\text { energiebedrijven }\end{array}$ & $89 \mathrm{MW}_{\mathrm{e}}$ & $58 \mathrm{MW}_{\mathrm{e}}$ & $23 \mathrm{MW}_{\mathrm{e}}$ & $19 \mathrm{MW}_{\mathrm{e}}$ & $17 \mathrm{MW}_{\mathrm{e}}$ & 0,092 & 0,021 & 0,012 & 0,007 & 0,061 & 0,014 & 0,008 & 0,004 \\
\hline Totaal & c) & c) & c) & c) & c) & $-2,94$ & $-2,55$ & $-2,54$ & $-2,28$ & 2,53 & 2,10 & 2,11 & 1,94 \\
\hline
\end{tabular}

$v=$ voorlopig cijfer

a) exclusief aandeel duurzaam; b) peildatum eind van het jaar; c) door het gebruik van meerdere wkk-vormen op hetzelfde areaal is sommatie niet mogelijk. 
Wageningen Economic Research Postbus 29703

2502 LS Den Haag

T 0703358330

E communications.ssg@wur.nl

www. wur.nl/economic-research

Wageningen Economic Research RAPPORT

2017-094
De missie van Wageningen University \& Research is 'To explore the potential of nature to improve the quality of life'. Binnen Wageningen University \& Research bundelen Wageningen University en gespecialiseerde onderzoeksinstituten van Stichting Wageningen Research hun krachten om bij te dragen aan de oplossing van belangrijke vragen in het domein van gezonde voeding en leefomgeving. Met ongeveer 30 vestigingen, 5.000 medewerkers en 10.000 studenten behoort Wageningen University \& Research wereldwijd tot de aansprekende kennisinstellingen binnen haar domein. De integrale benadering van de vraagstukken en de samenwerking tussen verschillende disciplines vormen het hart van de unieke Wageningen aanpak. 



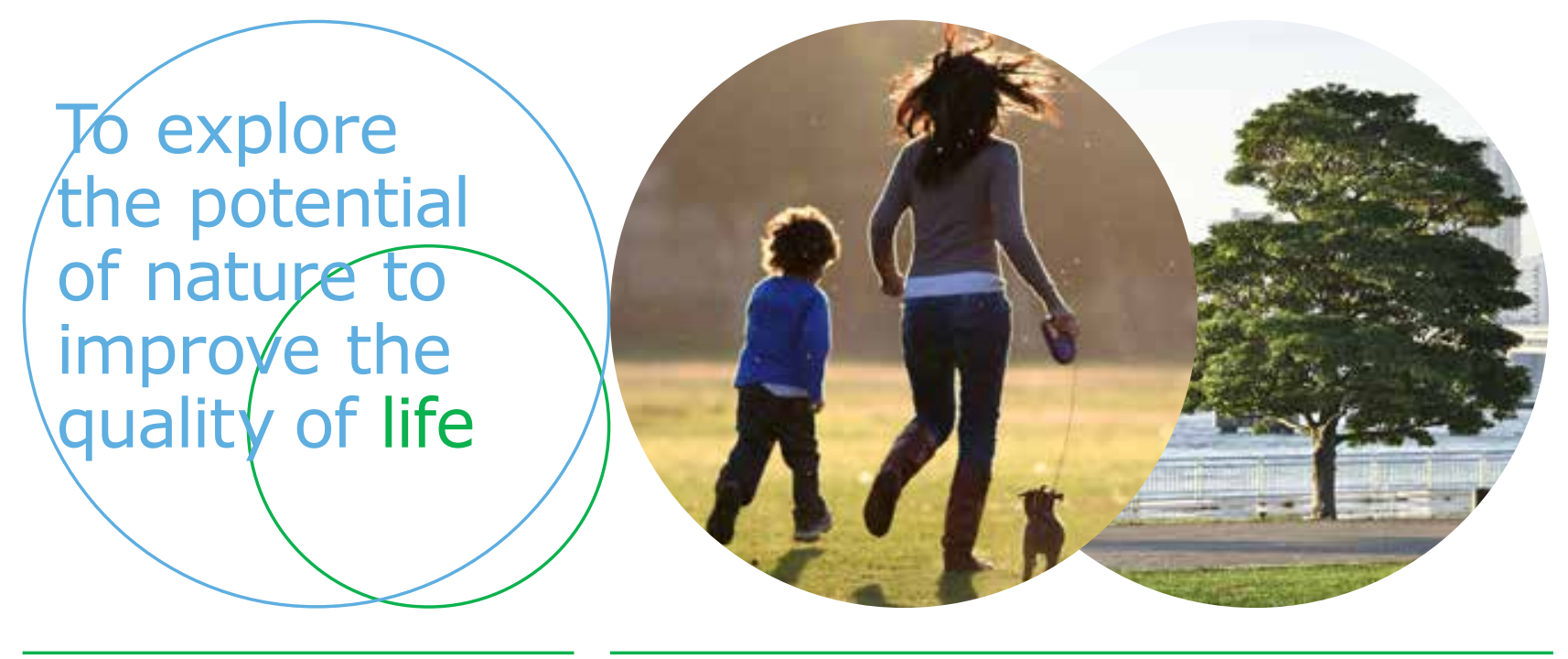

Wageningen Economic Research Postbus 29703

2502 LS Den Haag

E communications.ssg@wur.nl

$\mathrm{T}+31(0) 703358330$

www.wur.nl/economic-research

De missie van Wageningen University \& Research is 'To explore the potential of nature to improve the quality of life'. Binnen Wageningen University \& Research bundelen Wageningen University en gespecialiseerde onderzoeksinstituten van Stichting Wageningen Research hun krachten om bij te dragen aan de oplossing van belangrijke vragen in het domein van gezonde voeding en leefomgeving. Met ongeveer 30 vestigingen, 5.000 medewerkers en 10.000 studenten behoort Wageningen University \& Research wereldwijd tot de aansprekende kennis-

Report 2017-094

ISBN 978-94-6343-800-1 instellingen binnen haar domein. De integrale benadering van de vraagstukken en de samenwerking tussen verschillende disciplines vormen het hart van de unieke Wageningen aanpak. 